$$
\begin{aligned}
& \text { UNIVERSIDADE DE SÃO PAULO } \\
& \text { GLAUCIENE ANALHA LEISTER }
\end{aligned}
$$

\title{
A BUSCA POR CUIDADOS DE UMA MULHER QUE VIVE COM O HIV NO MUNICÍPIO DE SÃO PAULO-SP: OS NÓS CRÍTICOS \\ DA INTEGRALIDADE
}

\section{SÃO PAULO}

2012 


\section{GLAUCIENE ANALHA LEISTER}

\section{A BUSCA POR CUIDADOS DE UMA MULHER QUE VIVE COM O HIV NO MUNICÍPIO DE SÃO PAULO-SP: OS NÓS CRÍTICOS DA INTEGRALIDADE}

Dissertação apresentada ao Programa de Pós-Graduação da Escola de Enfermagem da Universidade de São Paulo, para obtenção do título de Mestre em Ciências.

Orientadora: Prof ${ }^{\mathrm{a}} \mathrm{Dr}^{\mathrm{a}}$ Lúcia Yasuko Izumi Nichiata

SÃO PAULO

2012 


\begin{abstract}
AUTORIZO A REPRODUÇÃO E DIVULGAÇÃO TOTAL OU PARCIAL DESTE TRABALHO, POR QUALQUER MEIO CONVENCIONAL OU ELETRÔNICO, PARA FINS DE ESTUDO E PESQUISA, DESDE QUE CITADA A FONTE.
\end{abstract}

Assinatura:

Data:

Catalogação na Publicação (CIP) Biblioteca "Wanda de Aguiar Horta" Escola de Enfermagem da Universidade de São Paulo

Leister, Glauciene Analha

A busca por cuidados de uma mulher que vive com HIV no município de São Paulo - SP: os nós da integralidade / Glauciene Analha Leister - São Paulo, 2012.

$145 \mathrm{p}$.

Dissertação (Mestrado) - Escola de Enfermagem da Universidade de São Paulo.

Orientadora: Prof ${ }^{a} \operatorname{Dr}^{a}$ Lúcia Yasuko Izumi Nichiata

Área de concentração: Saúde coletiva

1. HIV 2. Síndrome de Imunodeficiência Adquirida 3. Pesquisa qualitativa 4. Estudo de caso 5. Trajetória 6. Cuidados integrais de saúde I. Título. 
Nome: Glauciene Analha Leister

Título: A busca por cuidados de uma mulher que vive com HIV no Município de São Paulo-SP

Dissertação apresentada à Escola de Enfermagem da Universidade de São Paulo para obtenção do título de Mestre em Ciências.

Aprovada em:

Prof. Dr.

Julgamento:

Prof. Dr.

Julgamento:

Prof. Dr. Julgamento:
Instituição:

Assinatura:

Instituição:

Assinatura:

Instituição:

Assinatura: 


\section{DEDICATÓRIA}

Aos meus pais, Geraldo e Eliú, pelo Amor incomparável e por todos esforços ao investirem na minha formação pessoal e profissional.

Aos meus avós, José Rodrigues (in memoriam) e Lurdes, por me introduzirem o valor da dedicação, da honestidade e da serenidade

Ao meu esposo, Mauricio, por me dar a honra de compartilhar a vida $e$ por despertar a cada dia o valor do amor 


\section{AGRADECIMENTOS}

A Deus, pela energia da vida, pelo Seu Amor e pela Sua Paz em momentos de desafios.

A professora $D r^{a}$ Lúcia Yasuki Izumi Nichiata pela paciência, dedicação, pelos incentivos, por toda orientação cuidadosamente realizada e principalmente pela amizade durante todo este caminhar.

Às professoras $D r^{2}$ Renata Ferreira Takahashi e $D r^{2}$ Maria Rita Bertolozzi, pelo apoio prestativo e contribuições valiosas a este estudo, em todo o processo, desde o acolhimento no Grupo de Pesquisa Vulnerabilidade, Adesão e Necessidades em Saúde Coletiva.

Às professoras do Programa de Pós-Graduação do Departamento de Enfermagem em Saúde Coletiva (PPGE) da Escola de Enfermagem da USP por terem me introduzido às reflexões sobre a Saúde Coletiva e por todo precioso conhecimento compartilhado.

Às professoras $D r^{2}$ Roseni Pinheiro e $D r^{2}$ Roseney Bellato pelas pertinentes e fundamentais considerações no Exame de Qualificação e anteriormente à coleta de dados.

Aos membros do Grupo de Pesquisa Vulnerabilidade, Adesão e Necessidades em Saúde Coletiva, pelas contribuições em diferentes fases do trabalho, à Ferla Maria Bastos Cirino e à Fernanda Aparecida Franco, em especial à Luciane Ferreira do Val, pelo incentivo e por ter compartilhado momentos de aprendizagem durante o mestrado.

Às amigas de mestrado, Tharsila Martins Rios da Silva e Ana Paula Graziano por dividir alegrias, incertezas e simplesmente pela oportunidade de ter o prazer das suas amizades. 
A todos os colegas da UBS Jd. D'Abril pelo companheirismo, pela amizade, pelos aprendizados e à gerência, na pessoa de Mariana Jacob Bloch, por ter disponibilizado o campo de pesquisa.

Aos colegas da Pediatria do Hospital Universitário da USP pelo apoio no momento inicial deste trabalho.

Aos funcionários da biblioteca "Wanda de Aguiar Horta", aos da Secretaria de Pós-Graduação e aos do Departamento de Saúde Coletiva, em especial à Terezinha e Dayse pelo auxílio e orientações. E ao revisor Tiago, pelas pertinentes contribuições e atenção na fase final.

À minha querida família e à família do Mauricio, que desde sempre torceram pela minha prosperidade e por compreenderem os momentos de ausência.

À minha querida vozinha Lurdes pelas orações e pelo exemplo de fé.

Aos meus pais, Geraldo e Eliú, que me apoiaram, me protegeram, investiram na minha formação e me ensinaram os valores mais preciosos da vida. Minha profunda gratidão por todos os esforços que empreenderam, mesmo com dificuldades, e por me amarem com tão absoluta nobreza de coração e alma.

Aos meus irmãos, Gleicon e Glauber, pelo amor, pelo carinho, pela torcida em todos os momentos e por terem uma parte especial no meu coração.

Ao meu esposo, Mauricio, pelo incentivo, apoio, carinho, paciência; por compreender minha ausência nos períodos críticos do mestrado; e r ${ }^{\text {- }}$ acima de tudo, ser a pessoa que eu quero amar e conquistar todos os dias da minha vida.

E por fim, a todos os amigos, parentes e aos que indiretamente me ajudaram e fizeram parte deste processo, em especial à pessoa que Sofia representa. 
"O êxito da vida não se mede pelo caminho que você conquistou, mas sim pelas dificuldades que superou no caminho".

Abraham Lincoln 
Leister GA. A busca por cuidados de uma mulher que vive com o HIV no Município de São Paulo-SP: os nós críticos da integralidade. [dissertação]. São Paulo (SP): Escola de Enfermagem, Universidade de São Paulo; 2012. $146 p$

\section{RESUMO}

A magnitude da epidemia da aids e os desafios em garantir uma rede de atenção que atenda às necessidades das pessoas que vivem com HIV/AIDS justificam a realização do presente estudo, que tem por objetivos: contextualizar a trajetória em busca por cuidados de uma mulher que vive com HIV/AIDS e discutir os nós críticos da integralidade neste percurso. Trata-se de um estudo de caso, qualitativo e exploratório. Utilizou-se a História de Vida Focal e o Itinerário Terapêutico. Para análise dos resultados, utilizou-se a perspectiva teórico-conceitual da Integralidade, por meio da Análise de Discurso. Identificou-se neste percurso que os desafios de conviver com o HIV consistiram em: lidar com o risco da transmissão vertical; conviver com o medo de ter o diagnóstico revelado; e conciliar a rotina de vida com a manutenção da terapia antirretroviral. As fragilidades da integralidade neste percurso consistiram em: predominante visão biológica do adoecimento na Atenção Básica; falta de articulação entre UBS, SAEDST/AIDS e maternidade; falta de fluxos estruturados para a assistência da mulher com HIV na maternidade; e a invisibilidade do trabalho da enfermeira. Como potencialidades da integralidade: as Redes de Sustentação (família e amiga) e Apoio (trabalho, estudo, igreja e alguns profissionais de saúde); e a organização dos serviços ao favorecer acessibilidade à usuária no sistema de serviços de saúde. Concluiu-se que a articulação dos serviços ainda se encontra fragilizada e que está no usuário a centralidade da busca por cuidados, sendo ele e sua família, elos integradores entre os diferentes serviços assistenciais de saúde. Apontou-se a necessária implementação de Linhas de Cuidado na Atenção em HIV/AIDS, a fim de buscar integralidade na organização dos fluxos assistenciais.

PALAVRAS-CHAVE: HIV, Síndrome de Imunodeficiência Adquirida, Pesquisa Qualitativa, Estudo de Caso, Trajetória, Cuidados Integrais de Saúde 
Leister GA. The trajectory in search for care of a woman living with HIV in city of São Paulo-SP: the critical points of the Comprehensiveness. [paper]. São Paulo (SP): Nursing School, University of São Paulo; 2012. 144p

\begin{abstract}
The magnitude of the AIDS epidemic and the need for a network of comprehensive care to people living with HIV/AIDS justify the conduct of this study. The study aims were: to contextualize the trajectory in search for care of a woman living with HIV/AIDS and to discuss the critical points of the Comprehensiveness in this trajectory. This was a case-study, qualitative, exploratory, with the theoretical-conceptual of the Comprehensiveness. The method used was the Focused Life History and the Therapeutic Itinerary. The data were analyzed using the Fiorin's Technical Discourse. The study identified that there are challenges of living with HIV: afraid of the risk of vertical transmission during pregnancy; to omit the diagnosis of HIV for afraid of prejudice and social isolation; and to reconcile the routine of study, work, care for her daughter and her mother, with the need to remain adhered to antiretroviral therapy. The problems of the Comprehensiveness in this trajectory were: predominantly biological view of illness in Primary Health Care; lack of articulation between Basic Health Units, Reference Units on HIV/AIDS and maternity hospital; lack of structured flows for the assistance of women with HIV in maternity hospital; and invisibility of the nurse's work. As potential's Comprehensiveness: networks of support (family, friend, some health workers, church, work and study) and the organization of services to facilitate user access to the system of health services. It was concluded that the articulation of the services is still fragile and that the search for care has centrality in the user of health services. Furthermore, the study concluded that is the user of health services and her family that make link in the network of health services. The study indicated the necessary implementation of Lines of Care in HIV/AIDS Attention, to get Comprehensiveness in the organization of care flows.
\end{abstract}

KEYWORDS: HIV, Acquired Immune Deficiency Syndrome, Qualitative Research, Case Study, Trajectory, Comprehensive Health Care 


\section{LISTA DE ILUSTRAÇÕES}

Figura 1- Quadro 1- Categorias de análise e operatórias 36

Figura 2 - Mapa do Município de São Paulo

42

Figura 3 - Mapa do Distrito Butantã

42

Figura 4 - Genograma família Sofia

75

Figura 5 - IT temporal de Sofia

83

Figura 6 - Desenho espacial da trajetória empreendida por Sofia 86 


\section{LISTA DE SIGLAS}

$\begin{array}{ll}\text { AIDS } & \text { Síndrome da Imunodeficiência Adquirida } \\ \text { ARV } & \text { Antirretrovirais } \\ \text { COAS } & \text { Centro de Orientação e Aconselhamento Sorológico } \\ \text { CRTA } & \text { Centro de Referência e Treinamento em aids } \\ \text { DHDS } & \text { Divisão de Hansenologia e Dermatologia Sanitária do } \\ & \text { Instituto de Saúde } \\ \text { DST } & \text { Doença Sexualmente Transmissível } \\ \text { ESF } & \text { Estratégia Saúde da Família } \\ \text { HIV } & \text { Vírus da Imunodeficiência Humana } \\ \text { HVF } & \text { História de Vida Focal } \\ \text { IT } & \text { Itinerário Terapêutico } \\ \text { SAE } & \text { Serviço de Assistência Especializada } \\ \text { NOB93 } & \text { Norma Operacional Básica SUS 01/93 } \\ \text { PAS } & \text { Plano de Atendimento a Saúde } \\ \text { PVHA } & \text { Pessoa que vive com HIV/AIDS } \\ \text { SUS } & \text { Sistema Único de Saúde } \\ \text { UBS } & \text { Unidade Básica de Saúde }\end{array}$




\section{SUMÁRIO}

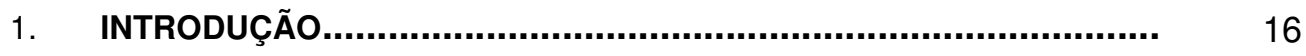

1.1. PANORAMA DA EPIDEMIA DA AIDS NO BRASIL............................ 17

1.2. POLÍTICA EM HIV/AIDS E A ORGANIZAÇÃO DOS SERVIÇOS DE SAÚDE NA CIDADE DE SÃO PAULO ....................................................................................... 21

2. OBJETIVOS....................................................................... 28

2.1. OBJETIVO GERAL............................................................... 29

2.2. OBJETIVOS ESPECÍFICOS...................................................... 29

3. METODOLOGIA ................................................................ 30

3.1. OPÇÃO METODOLÓGICA.................................................... 31

3.2. PERSPECTIVA TEÓRICO-CONCEITUAL..................................... 31

3.3. ESTRATÉGIA METODOLÓGICA.............................................. 37

3.4. LOCAL DO ESTUDO................................................................. 41

3.5. IDENTIFICAÇÃO DO SUJEITO DE PESQUISA E PROCEDIMENTOS DA COLETA DE DADOS.............................................................. 45

3.6. ANÁLISE DOS DADOS............................................................. 48

3.7. ASPECTOS ÉTICOS............................................................. 50

4. RESUltados: O PERCURSO EMPREENDIDO EM BUSCA POR CUIDADOS E AS FONTES DE SUSTENTAÇÃO E APOIO..................... 51

4.1. O PERCURSO EM BUSCA POR CUIDADOS: ACESSO AOS SERVIÇOS E AS PRÁTICAS DE SAÚDE........................................ 52

4.2. FONTES DE APOIO E SUSTENTAÇÃO NA TRAJETÓRIA EM BUSCA POR CUIDADOS...................................................................... 
5. DISCUSSÃO: ITINERÁRIO TERAPÊUTICO: FRAGILIDADES E POTENCIALIDADES NO EXERCícIO DA INTEGRALIDADE NO PERCURSO EM BUSCA POR CUIDADOS..................................... 80

5.1. ITINERÁRIO TERAPÊUTICO: FRAGILIDADES NO EXERCÍCIO DA INTEGRALIDADE NO PERCURSO EM BUSCA POR CUIDADOS.................................................................................

5.2. ITINERÁRIO TERAPÊUTICO: PRÁTICAS QUE POTENCIALIZARAM O EXERCÍCIO DA INTEGRALIDADE............................................... 109

6. CONCLUSÃO E CONSIDERAÇÕES FINAIS.................................... 116

7. REFERÊNCIAS ................................................................ 121

APÊNDICES ............................................................................ 132

APÊNDICE 1 - Termo de Consentimento Livre e Esclarecido........................ 133

APÊNDICE 2 - Orçamento Detalhado do Projeto....................................... 135

APÊNDICE 3 - Frases temáticas extraídas das narrativas........................... 136

ANEXO ................................................................................ 143

ANEXO 1 - Parecer de aprovação do Comitê de Ética da Prefeitura de São Paulo 


\section{APRESENTAÇÃO}

Meu primeiro contato com a temática HIV/AIDS foi por meio da graduação, em 2008, durante estágio extracurricular no Hospital Dia do Hospital das Clínicas da Universidade Estadual de Campinas, unidade, na época, direcionada exclusivamente ao atendimento de pessoas vivendo com HIV/AIDS. Como primeira vivência, o curto período de estágio foi de caráter apenas exploratório, mas algumas questões surgiram nessa experiência, tais como a pouca articulação do Hospital Dia com os outros níveis de complexidade e a concentração da assistência ao HIV/AIDS predominantemente nesta instituição. Porém tais questões se esvaneceram diante das posteriores experiências profissionais.

Como enfermeira, atuei em um Hospital Universitário na unidade de internação pediátrica, porém o contato com a temática HIV/AIDS foi bastante restrito. Nesta ocasião, buscando dar outro rumo à carreira profissional, tive a oportunidade de ingressar no grupo de pesquisa "Vulnerabilidade, Adesão e Necessidades em Saúde Coletiva", do Departamento de Enfermagem em Saúde Coletiva, cadastrado no CNPq, da Escola de Enfermagem da USP, momento em que me aproximei das discussões sobre vulnerabilidades em saúde e, dentro dessas questões, a temática da aids esteve sempre presente. Logo em seguida ingressei como aluna especial no programa de pós-graduação da Escola de Enfermagem da USP, ocasião em pude confirmar meu interesse pela Saúde Coletiva e pelas discussões que envolviam o grupo de pesquisa acerca da vulnerabilidade.

Desde então, ao participar dos produtivos encontros deste grupo de pesquisa, pude me aproximar mais dos projetos desenvolvidos e ingressei no projeto maior intitulado "Vulnerabilidade programática ao HIV/AIDS e os desafios da integralidade: enfrentamento do HIV/AIDS na Estratégia Saúde da Família". Assim, o presente trabalho de dissertação de mestrado é parte deste projeto mais amplo. 
Já na condição de enfermeira da Estratégia Saúde da Família pude resgatar os meus antigos questionamentos sobre a atenção em HIV/AIDS e pude constatar empiricamente que a maioria desta população é atendida nos serviços de saúde de atenção especializada, praticamente com pouca participação da atenção básica. Assim, após tomar contato com as discussões sobre vulnerabilidade em saúde, pude entender que a atenção básica também possui importante responsabilidade no enfrentamento da aids. Assim, buscando compreender alguns questionamentos sobre a articulação dos serviços no enfrentamento ao HIV/AIDS, iniciei o projeto de pesquisa, com o objetivo de entender como se delineava então a trajetória desses usuários que buscam cuidados aos seus problemas de saúde. 
1. INTRODUÇÃO 


\section{INTRODUÇÃO}

O presente trabalho se propõe a fazer um estudo sobre a trajetória de uma pessoa que vive com HIV em busca por cuidados. Compreende-se que as escolhas que esse indivíduo possui, ao procurar cuidados relacionados ao HIV, são influenciadas diretamente pelo modo como os serviços de saúde estão organizados.

Assim, considerando a importância do panorama da epidemia da aids na organização de respostas de enfrentamento, e, portanto, na organização de serviços de saúde na Atenção em HIV/AIDS, o estudo questiona como a trajetória de uma pessoa vivendo com HIV expressa a organização desses serviços.

Desta forma, tal discussão se inicia na Introdução, em que se apresenta o panorama da epidemia da aids no Brasil e a conformação de respostas de enfrentamento no que tange a programas e serviços.

A partir da apresentação que se inicia no Capítulo 1, com a Introdução, nos resultados contextualiza-se o percurso em busca de cuidados, tendo como categoria de análise a Integralidade. Após ilustração desse percurso, por meio do itinerário terapêutico, no último capítulo discutem-se os nós críticos da integralidade nesta busca por cuidados.

\subsection{PANORAMA DA EPIDEMIA DA AIDS NO BRASIL}

No Brasil, os primeiros casos da Síndrome da Imunodeficiência Adquirida (AIDS) ocorreram na década de 1980. Deste ano a junho de 2011, registraram-se 608.230 casos de aids, sendo $397.662(65,4 \%)$ do sexo 
masculino e $210.538(34,6 \%)$ do sexo feminino. Apenas em 2010, houve 34.218 casos de aids notificados, sendo 12.846 do sexo feminino, o que representa $37.54 \%$ dos casos diagnosticados (Brasil, 2011).

Em 2010 a taxa de incidência foi de 17,9 por 100.000 habitantes e o coeficiente de mortalidade, 6,3 por 100.000 habitantes. De 1980 a 2010, foram 241.469 óbitos por aids no País, sendo 174.394 óbitos do sexo masculino e 66.966 do sexo feminino (Brasil, 2011).

É importante destacar que a epidemia teve uma curva ascendente até 1995, com posterior queda na taxa de incidência. A partir desse ano, observa-se tendência à estabilização da epidemia, contudo em patamares elevados nos últimos anos (Brasil, 2008a, 2009a, 2010a e 2011).

Com relação à distribuição geográfica da epidemia, observa-se maior concentração dos casos na região Sudeste (59,3\% dos casos), embora com declínio na taxa de incidência nos últimos anos. Também se verifica esse declínio na região Centro-Oeste, que concentra $5,7 \%$ dos casos. Um panorama diferente é encontrado nas demais regiões brasileiras, em que se observa aumento na taxa de incidência, tanto no Norte (que concentra 3,9\% dos casos), quanto no Nordeste (11,9\% dos casos) e no Sul (19,2\%) (Brasil, 2009a).

O panorama estatístico ao longo dos anos (Brasil, 2008a, 2009a, 2010a e 2011) permitiu a observação de tendências e características no perfil da epidemia, que alguns pesquisadores chamam de fenômenos da interiorização, feminização, heterossexualização, juvenilização, pauperização e cronicidade - tendências estas que orientam a configuração de respostas de enfrentamento (Nichiata, 2010).

Apesar de a maioria das ocorrências concentrarem-se principalmente nas grandes regiões urbanas, a partir da década de 1990 vem se observando propagação crescente da epidemia para municípios distantes das importantes áreas metropolitanas, afetando principalmente as cidades 
menos assistidas, fenômeno este conhecido como interiorização (Reis et al., 2008).

Outro fenômeno relacionado à aids no Brasil é a diminuição, ao longo dos anos, na razão entre os sexos masculino e feminino (M:F), caracterizando a velocidade da infecção no sexo feminino ao longo dos anos. Embora ainda haja no País predomínio de casos de aids no sexo masculino, verifica-se um crescimento maior no número de mulheres infectadas, fenômeno conhecido como feminização da epidemia. Em 1986, a razão era de 15,1:1 e, em 2002, passou a ser de 1,5:1, a qual se manteve até 2009, quando se elevou a 1,6:1. Em 2010, registrou-se um pequeno aumento - 1,7:1 (Brasil, 2011).

Segundo o Boletim Epidemiológico de Aids HIV/DST e Hepatites B e $C$ do Município de São Paulo, neste município, a razão de sexo M:F, que era de 23:1 em 1986, passou a ser de 2:1 em 2009. Esse Boletim também informa o aumento percentual do número de casos na categoria de exposição heterossexual, principalmente em mulheres (São Paulo, 2010a).

Também vale destacar que, no início da epidemia, a aids estava vinculada ao público homossexual e ao uso de drogas injetáveis. Nos últimos anos constata-se tendência à heterossexualização, tendo em vista o número cada vez maior de heterossexuais portadores da doença. Além disso, observa-se estabilização dos casos entre homo/bissexuais e também redução entre os usuários de drogas injetáveis (Brasil, 2009a).

Ao analisar a faixa etária mais afetada, os casos concentram-se nos indivíduos entre 25 e 49 anos, caracterizando uma tendência da epidemia à juvenilização. Considerando um período de cerca de dez anos entre a transmissão e o início dos sintomas que efetivamente os caracterizam como casos de aids, é a população adolescente e adulta jovem que se encontra altamente vulnerável ao HIV. Ao mesmo tempo, percebe-se um incremento na taxa de incidência em indivíduos maiores de cinquenta anos, tanto homens quanto mulheres, conformando-se em um processo de 
"envelhecimento da epidemia" Ainda é importante destacar que o coeficiente de mortalidade na faixa etária acima de cinquenta anos também vem apresentando crescimento em todas as regiões do Brasil (Brasil, 2011).

Com relação à escolaridade das pessoas vivendo com HIV/AIDS, destaca-se, durante ao longo dos anos, aumento proporcional de casos na população com oito a onze anos de estudo, aumentando de $18,7 \%$, em 2001, para 30,1\% em 2011 (Brasil, 2011).

Outro fenômeno observado é a pauperização, que está relacionada à difusão do HIV/AIDS nos estratos mais pobres, resultado das iniquidades sociais. Entre vários fatores determinantes desta condição, estão: acesso desfavorável ao mercado de trabalho; condições sociais precárias; e barreiras estruturais, culturais e sociais, que, de forma geral, dificultam o acesso aos recursos de prevenção (Bastos Szwarcwald, 2000).

É importante citar o fenômeno da cronicidade. Após o advento dos antirretrovirais e, principalmente, com a descoberta dos inibidores da protease, verificou-se importante redução nos índices de morbidade e mortalidade no perfil da epidemia (Brasil, 2005). O viver com HIV/AIDS passou a ter um novo significado - de uma visão reduzida de indivíduo doente para uma ampliada de um indivíduo que convive com o HIV ao longo dos anos, conferindo à aids uma conformação de doença crônica (Schaurich, Coelho, Motta, 2006).

Esta complexa configuração da epidemia da aids vem exigindo novas respostas de enfrentamento, tanto no que tange às políticas públicas, quanto diretamente no que se refere à organização dos serviços de saúde, o que será tratado a seguir. 


\subsection{POLÍTICA EM HIV/AIDS E A ORGANIZAÇÃO DOS SERVIÇOS DE SAÚDE NA CIDADE DE SÃO PAULO}

A partir do que se expõe acima sobre a configuração da epidemia ao longo dos anos, neste subcapítulo aborda-se a conformação de respostas de enfrentamento, partindo de um resgate histórico de alguns eventos que tiveram grande influência no desenvolvimento das políticas relacionadas ao HIV/AIDS.

Após anos de ditadura militar, o País vivia contexto de redemocratização e maior inserção da população nas discussões sobre as políticas públicas. Destaca-se como importante participação popular nesta época o Movimento da Reforma Sanitária, que teve início no final da década de 1970 e estendeu-se para a década de 1980. Tal efervescência trouxe contribuições na política de enfrentamento da epidemia da aids. Como exemplo desta participação, foi notável a atuação dos militantes pelos direitos dos homossexuais, que em 1983 procuraram a Secretaria do Estado de São Paulo exigindo respostas diante da problemática HIV/AIDS (Teixeira, 1997; Pereira, Nichiata, 2011).

Assim, em 1983 iniciaram-se as primeiras atividades de controle da epidemia pela Secretaria de Estado da Saúde de São Paulo, sob gestão do então secretário estadual de saúde o médico João Yunes, importante militante do Movimento Sanitário. A primeira resposta de enfrentamento da epidemia foi a criação de um grupo de trabalho composto por técnicos da Divisão de Hansenologia e Dermatologia Sanitária do Instituto de Saúde (DHDS), com a participação de representantes dos movimentos homossexuais. Incumbidos de formular e implementar as primeiras ações de enfrentamento da epidemia, tinham como objetivos realizar o diagnóstico, controle, orientação e tratamento dos casos de HIV/AIDS (Guerra, 1993; Teixeira, 1997). A assistência hospitalar foi destinada ao Hospital Emílio 
Ribas e a retaguarda ambulatorial ao Instituto Adolf Lutz (Monteiro, Oliveira, 2007).

Em 1988, foi criado o Centro de Referência e Treinamento em aids (CRTA), serviço vinculado ao Programa Estadual de DST/AIDS, sob a gestão da Secretaria de Estado da Saúde de São Paulo, que tinha como objetivo realizar atividades assistenciais, de vigilância epidemiológica e de capacitação dos trabalhadores do Estado para a assistência à aids (Kalichman, 1993; Nichiata, Shima, Takahashi, 1995).

Assim, o programa paulista foi pioneiro no enfrentamento em HIV/AIDS. Mais tardiamente, quando já era grande o volume dos casos de aids em municípios de pequeno e grande porte, foi criado o Programa Nacional de Combate ao HIV/AIDS (PN-DST/AIDS), em 1986, quando onze estados já contavam com programas estruturados. Em âmbito nacional, destacam-se ações do PN-DST/AIDS, tais como a inclusão da aids como doença de notificação compulsória, em 1986 (Kalichman, 1993) e a formalização do Dia Internacional de Luta Contra a Aids em calendário nacional (Nichiata, 2010). Reconhece-se também, em forma de lei, a importância da inclusão de benefícios às pessoas que vivem com HIV/AIDS no benefício para doenças incapacitantes e terminais, como o Fundo de Garantia por Tempo de Serviço e o auxílio doença, pensão e aposentadoria, sem período de carência (Brasil, 1988).

Ainda em âmbito nacional, destaca-se o controle laboratorial do sangue e hemoderivados em todo território nacional (Brasil, 2004) e a implantação dos serviços de saúde de aconselhamento e realização de testes antiaids em serviços denominados de Centro de Orientação e Apoio Sorológicos, hoje os Centro de Testagem e Aconselhamento (Kalichman, 1993). E de grande destaque, tem-se o acesso universal e gratuito ao tratamento com antirretrovirais (Brasil, 1996; Nichiata, 2010).

No município de São Paulo, as primeiras ações de âmbito de responsabilidade da Secretaria Municipal da Saúde se iniciaram em 1987, 
com a criação do Programa Municipal de Prevenção e Controle de DST/AIDS. Dentre as ações, este Programa foi responsável pela capacitação de profissionais no atendimento em HIV/AIDS (Gryscheck, 2001) e pela ampliação do número de leitos hospitalares destinados aos doentes com HIV/AIDS. Em 1989, com o apoio do PN-DST/AIDS, foi criado o primeiro Centro de Orientação e Aconselhamento Sorológico (COAS) do País, voltado à avaliação sorológica anônima e confidencial, ao aconselhamento sobre HIV/AIDS à população em geral e a grupos específicos, desenvolvendo assim, atividades de prevenção e diagnóstico precoce do HIV/AIDS. Este pode ser considerado uma nova modalidade de serviço até então não existente no país, que permitiu conhecer de modo precoce o perfil epidemiológico dos indivíduos infectados, antes que fossem notificados como casos de aids (Nichiata, Shima, Takahashi, 1995; Bassichetto et al.,2004; Nichiata, 2010).

$\mathrm{Na}$ década de 1990, foram criadas unidades assistenciais a pessoas vivendo com HIV, tais como o Centro de Referência, os Serviços de Assistência Especializada e os Ambulatórios de Especialidades. Essas unidades especializadas ofereciam atendimento ambulatorial, em regime de hospital-dia e atendimento domiciliar terapêutico (Gryscheck, 2001, Nichiata, 2010).

Vale destacar que este arcabouço de organização dos serviços em HIV/AIDS no município foi impulsionado pelos recursos financeiros provenientes de empréstimos do Banco Mundial, cujas negociações se iniciaram com o Ministério da Saúde e as secretarias de estado. Tal financiamento (projeto AIDS I) teve como finalidade estabelecer um novo plano estratégico para o controle da aids, promovendo benefícios, em todo o país, para os municípios considerados prioritários. Em 1999, com o financiamento do projeto AIDS II, ampliaram-se as ações para as populações em situação de pobreza e, dentre as estratégias propostas, foram incluídas ações para alcançar a articulação entre os serviços de assistência especializada em HIV/AIDS com os da Atenção Básica, num 
movimento de descentralização das ações de enfrentamento das DST/AIDS (Monteiro, Oliveira, 2007).

Este movimento coincide com a diretriz geral do Sistema Único de Saúde (SUS), que já vinha sendo implementado no País, principalmente depois da promulgação das Leis Orgânicas de Saúde nº 8.080/90 e 8.142/90, efetivada em 1993 com a regulamentação da Norma Operacional Básica SUS 01/93 (NOB93). Tal legislação promulgou o processo de descentralização e municipalização da gestão dos serviços e ações no âmbito do SUS e estabeleceu mecanismos de financiamento das ações de saúde. Desde então, os municípios assumiram gestão semiplena, o que possibilitou a eles maior capacidade de gestão e autonomia (Brasil, 1993). Em 1996, com a aprovação da Norma Operacional Básica de 1996 - NOB96 - os municípios assumiram a gestão plena (Brasil, 1997).

No município de São Paulo ocorreu uma situação peculiar no processo de descentralização e municipalização, quando se institui na cidade o Plano de Atendimento a Saúde (PAS), no período de 1993 a 2000. O PAS foi uma parceria firmada entre a Secretaria Municipal e os agentes privados que contava com o repasse de recursos públicos para as cooperativas, atribuindo a estas a responsabilidade pela gestão das unidades de saúde, o que incluía desde a Atenção Básica até os serviços especializados, contudo em desacordo com os princípios e diretrizes da gestão do SUS. Desta forma, a gestão plena demora a se concretizar, o que, segundo análise de Mesquita, Turienzo (2003), significou retrocesso no processo de implementação do SUS. Assim, a gestão plena da saúde no município só veio a ocorrer em 2001, assumindo-se a Estratégia Saúde da Família (ESF) no município como prioritário modelo de organização da atenção básica (Bousquat, Cohn, Elias, 2006).

Paradoxalmente, foi justamente este atraso do município de São Paulo em implementar o SUS que fortaleceu o Programa Municipal de DST/AIDS. Houve um incremento de trabalhadores da rede municipal para o 
programa e para a rede de serviços de DTS/AIDS. Esses trabalhadores, engajados na defesa das políticas públicas, não aceitaram ser incorporados ao PAS, o que favoreceu a consolidação das ações de enfrentamento da epidemia no município (Turienzo, Mesquita, 2003).

Vale destacar que, neste período inicial, as organizações da sociedade civil tinham importante atuação em ações de prevenção mais amplas, envolvendo a discussão sobre os direitos sexuais, o combate ao preconceito e à discriminação, além da divulgação sobre as formas de proteção para evitar a transmissão (Pereira, Nichiata, 2011).

Por sua vez, a rede de serviços da Atenção Básica, como as unidades básicas de saúde, realizava ações de prevenção de forma muito insipiente, até o final da década de 1990 (Ferraz, Nemes, 2009). As ações da atenção básica estavam voltadas em particular às mulheres em período gestacional, que, em relação ao HIV, restringiam-se à disponibilização da sorologia antiHIV, ação implementada a partir de 1997 (Brasil, 1997).

Foi o reconhecimento da profilaxia antirretroviral na diminuição do risco de transmissão vertical do vírus, somado à mudança do perfil da epidemia, no que tange à feminização e heterossexualização, que favoreceram as discussões sobre a implantação de ações em HIV/AIDS na Atenção Básica (Ferraz, Nemes, 2009). Dentre as ações propostas para desenvolvimento na Atenção Básica estão: atividades de prevenção, detecção, educação e aconselhamento em HIV/AIDS, bem como tratamento das DST por abordagem sindrômica (Ferraz, Nemes, 2009). Além destas, a Atenção Básica também vem sendo responsável pela identificação e inclusão nos serviços dos seguimentos populacionais mais vulneráveis e pelas ações voltadas aos indivíduos já infectados pelo HIV, as quais se relacionam à adesão ao tratamento (Monteiro, Oliveira, 2007; São Paulo, 2003).

O município de São Paulo, ao assumir a gestão plena da saúde em 2001 e ao optar pela Estratégia Saúde da Família (ESF) como eixo de 
estruturação da Atenção Básica, vem ampliando as ações de prevenção das DST/AIDS. Portanto, ao considerar a importância da Atenção Básica no enfrentamento da epidemia, a rede de serviços se amplia, tendo em vista a existência de 439 Unidades Básicas de Saúde, destas, 256 com a ESF (São Paulo, 2010). Na Rede Municipal Especializada em DST/AIDS, o enfrentamento da epidemia conta com dez serviços de assistência especializada ( $\mathrm{SAE}$ ), dois ambulatórios de especialidades ( $\mathrm{AE}$ ), três centros de referência, nove CTA e três laboratórios de Saúde Pública em DST/AIDS (São Paulo, 2011, São Paulo, 2012a).

Diante dessa rede de serviços de saúde voltada à atenção em HIV/AIDS, questiona-se neste trabalho como que, na perspectiva do usuário que vive com HIV, a trajetória em busca por cuidados expressa a organização dos serviços de saúde, estruturados para o atendimento dessa população; e quais são as fragilidades e potencialidades da Integralidade neste percurso.

Estudos sobre a trajetória de pessoas que vivem com HIV/AIDS demonstram a potência que estes percursos possuem em favorecer reflexões importantes sobre a Atenção em HIV/AIDS (Ferreira, 2011; Maliska, Padilha, 2007; Longa, Takahashi, 1999; Silva, Takahashi, 2008). Os trabalhos apontam que a perspectiva do usuário permite amplas discussões, que envolvem temas desde a caracterização das práticas de cuidado; a experiência do adoecimento, no que se diz respeito à adesão a terapia antirretroviral; até discussões sobre a caracterização das representações sociais das PVHA e as relações existentes entre tais representações e o modo de enfrentar o adoecimento. Por meio da trajetória do usuário também é possível discutir os significados atribuídos por estas pessoas ao processo de adoecimento e do seguimento terapêutico que recebem nos serviços de assistência em HIV/AIDS.

Assim, ao considerar a importância da perspectiva avaliativa da pessoa que vive com HIV, este trabalho busca além de contextualizar este 
percurso, por meio do itinerário terapêutico, discutir os nós críticos da integralidade nesta trajetória empreendida em busca por cuidados.

Tendo em vista o que foi apresentado, justifica-se o desenvolvimento do estudo pela magnitude com que se apresenta a epidemia e os desafios postos na atualidade em termos da garantia de uma rede de atenção em HIV/AIDS que atenda às necessidades das pessoas em geral e daquelas que vivem com HIV/AIDS. Além disso, o estudo possibilita reflexão sobre como a organização dos serviços de saúde direciona a trajetória em busca por cuidados. Ao propiciar tal reflexão, favorece o planejamento de intervenções que fortaleçam o enfrentamento da epidemia e propiciem caminhos para a consolidação da integralidade. $E$ assim, o estudo teve como finalidade oferecer subsídios à Política de HIV/AIDS na cidade de São Paulo.

Elege-se como pressuposto que o itinerário percorrido pelo indivíduo em busca de cuidados de saúde tem potencial para desvelar fragilidades na rede de atenção em HIV/AIDS e direcionar as lacunas a serem trabalhadas. 


\section{OBJETIVOS}




\section{OBJETIVOS}

\subsection{OBJETIVO GERAL}

Analisar, na perspectiva da integralidade, a trajetória em busca por cuidados em saúde de uma pessoa que vive com HIV/AIDS e compreender como este percurso expressa a organização dos serviços estruturados para responder aos seus problemas de saúde.

\subsection{OBJETIVOS ESPECÍFICOS}

- Contextualizar o percurso realizado por uma pessoa que vive com HIV em busca de cuidados;

- Discutir os nós críticos da integralidade nos percursos empreendidos em busca de cuidados por uma pessoa que vive com HIV . 
3. METODOLOGIA 


\section{METODOLOGIA}

\subsection{OPÇÃO METODOLÓGICA}

Para o alcance dos objetivos do trabalho, foi realizado um Estudo de Caso, de caráter exploratório e de natureza qualitativa. Para delinear a trajetória de um usuário soropositivo nos serviços de saúde no município de São Paulo, optou-se por trabalhar com a História de Vida Focal, por meio da entrevista em profundidade. A fim de mapear o percurso realizado pelo usuário nos serviços de saúde, foi utilizado o Itinerário Terapêutico (IT), cuja definição se apresenta adiante.

\subsection{PERSPECTIVA TEÓRICO-CONCEITUAL}

A perspectiva teórico-conceitual central do trabalho, ao tomar a articulação entre os serviços de saúde, é a integralidade. Para uma primeira aproximação à noção da integralidade, recorre-se ao texto da Constituição de 1988, no artigo 198, da Seção Saúde, que aborda esse princípio como uma diretriz que diz respeito ao "atendimento integral, com prioridade para as atividades preventivas, sem prejuízo dos serviços assistenciais" (Brasil, 1988). Na legislação 8.080/1990, no Capítulo II, dos Princípios e Diretrizes, no artigo $7^{\circ}$, a integralidade é colocada como princípio, "entendida como conjunto articulado e contínuo das ações e serviços preventivos e curativos, individuais e coletivos, exigidos para cada caso em todos os níveis de complexidade do sistema..... (Brasil, 1990). 
Segundo Mattos (2001, p. 40), pode-se considerar que o sentido da integralidade como princípio vai além do que está definido como diretriz constitucional. Seus significados tentam expressar "um conjunto de valores pelos quais vale lutar, pois se relacionam a um ideal de uma sociedade mais justa e mais solidária". Desta forma, a integralidade assume caráter polissêmico, abraçando vários sentidos correlacionados e articulados entre si, embutidos num mesmo contexto de conquista e superação do que se almeja transformar na realidade atual e futura.

Pelo caráter polissêmico da integralidade e com o intuito de promover reflexões acerca dos seus limites e potencialidades na construção de políticas e práticas de saúde, Mattos (2001) propõe alguns sentidos que, embora estejam relacionados, são apresentados separadamente a seguir. $O$ primeiro relaciona-se ao sentido da não fragmentação do indivíduo em patologias ou órgãos; o segundo discute a necessidade de um conjunto de serviços articulados; e o terceiro abrange discussões sobre a formulação e execução de políticas públicas que estejam integradas (Magalhães Júnior, Oliveira, 2006).

O primeiro sentido adveio do movimento denominado medicina integral, que criticava a prática médica por tornar-se cada vez mais fragmentada e reducionista. Formado na lógica da supervalorização das especialidades e favorecido pela organização disciplinar do conteúdo acadêmico, o corpo médico tendia a analisar o indivíduo tão somente pelo viés do sistema que se especializaram, desconsiderando, assim, questões psicológicas e sociais e, consequentemente, as necessidades mais amplas dos pacientes. Esta crítica ganhou corpo e influenciou principalmente a mudança curricular das escolas médicas, a fim de propiciar a formação de profissionais menos reducionistas e com visões menos fragmentadas. Ao longo do tempo, esse movimento teve proximidade com os departamentos de medicina preventiva e, posteriormente, com o campo da Saúde Coletiva, o que favoreceu uma renovação teórica (Mattos, 2001). 
Na década de 1970, a Saúde Coletiva nascia no Brasil como campo de conhecimento que considerava as práticas em saúde como práticas sociais e que discutia a fragmentação e o reducionismo das escolas médicas como reflexo, na verdade, da organização econômica da sociedade. Tal relação era colocada principalmente devido ao crescente assalariamento dos médicos e à crise da medicina liberal, que, por meio das articulações entre Estado, serviços de saúde e indústrias farmacêuticas, fortalecia cada vez mais o complexo médico-industrial (Mattos, 2001).

A Saúde Coletiva, embasada na visão de mundo marxista, é um campo teórico e prático fundamentada no Materialismo Histórico e Dialético, que emergiu como crítica à visão positivista e base do capitalismo. Esta visão positivista permite a visualização parcial e dicotomizada da realidade e considera os aspectos sociais apenas como fatoriais e não como determinantes, reduzindo o processo saúde-doença às condições de equilíbrio/desequilíbrio e desconsiderando que este processo é determinado historicamente pela inserção do ser humano na sociedade (Egry, Oliveira, Fonseca, 2008).

A Enfermagem engrossa o movimento da Saúde Coletiva nos debates em torno do seu necessário reconhecimento como trabalho para além de suas competências profissionais. Enquanto parcela do trabalho em saúde, a Enfermagem contribui na produção dos serviços em nível coletivo e não como instrumento do trabalho médico. A redefinição do seu objeto de trabalho, o cuidado em saúde, passa a ter como base as necessidades de saúde da população, tomadas de forma ampliada (Almeida, Rocha, 1997). Desta forma, para considerar a Enfermagem enquanto trabalho, é necessário entender que as práticas de saúde são sociais e que tais práticas são determinadas pela finalidade social do trabalho em saúde (Fracolli, Bertolozzi, 2008).

Ao tomar o indivíduo, a família ou a comunidade como objeto de intervenção, as práticas profissionais devem ser norteadas pela 
integralidade, principalmente porque não se trata de cuidar de "partes", mas de um todo, seja no âmbito familiar, individual ou dos grupos sociais (Antunes, Guedes, 2010).

O segundo sentido refere-se mais diretamente à estruturação dos serviços e das práticas de saúde, que estão intimamente relacionados à configuração das políticas e ao modelo de organização da assistência. $\mathrm{Na}$ década de 1970, o antigo Sistema Nacional de Saúde direcionava as práticas de saúde pública ao Ministério da Saúde, e a assistência médica ao Ministério da Previdência Social, resultando em estrutura dicotomizada do sistema de saúde, que inclusive trouxe repercussões nas organizações atuais. Mesmo com a criação do Sistema Único de Saúde (SUS), importante marco pela unificação, a fragmentação ainda persiste (Mattos, 2001).

No SUS, embora ainda existam limitações no que se refere à garantia da integralidade, é importante ressaltar que estratégias visando à articulação dos serviços vêm sendo realizadas. Destaca-se, dentre elas, a introdução de prontuários unificados, o que vem reduzindo a fragmentação no interior das unidades. Outra estratégia na tentativa de integrar assistência e prevenção é a introdução de práticas assistenciais nas UBS, por meio da demanda espontânea e também programada, que inclusive deveriam estar organizadas para realizar apreensão ampliada das necessidades da população (Mattos, 2001).

Outra proposta de articulação dos serviços é a integração deles por redes assistenciais. Esta iniciativa considera a interdependência dos atores e das organizações e reconhece que, isoladamente, não possuem recursos e competências suficientes para a resolução dos problemas ampliados de saúde de uma população. Desta forma, torna-se,

\footnotetext{
indispensável desenvolver mecanismos de cooperação e coordenação próprios de uma gestão eficiente e responsável dos recursos coletivos, a qual responda às necessidades de saúde individuais em âmbitos local e regional (Hartz, Contandriopoulos, 2004. p.S331).
} 
Como estratégia de gestão, a integralidade favorece a utilização de medidas que avaliem as lacunas das redes assistenciais e possibilita a definição de foco nos processos de avaliação das ações programáticas de saúde (Hartz, Contandriopoulos, 2004). Além disso, a importância de se estudar a integralidade está no potencial reflexivo que ela possibilita, no sentido de características e valores que se desejam construir no sistema de saúde, bem como no direcionamento sobre o que se deseja imprimir nesse sistema (Mattos, 2001).

O terceiro sentido, proposto por Mattos (2001), está relacionado à estruturação de políticas que deem respostas adequadas aos problemas de saúde que atingem determinados grupos. $\mathrm{O}$ autor lembra que a resposta política não está restrita ao sentido de programa verticalizado, mas sim à dimensão mais abrangente de estratégia governamental.

Este sentido tem ampla abordagem, tanto no que se refere à configuração de políticas que considerem as questões sobre raça/etnia, gênero e geração de um grupo, quanto na estruturação de políticas que fortaleçam a articulação entre as ações curativas e preventivas. Por exemplo, para o grupo de pessoas vivendo com HIV/AIDS, este sentido abordaria a estruturação de políticas que atendessem aos problemas que se referem à etnia, gênero e geração deste grupo, considerando inclusive o perfil da epidemia ao longo dos anos e também incluiria políticas que promovam a articulação entre as áreas preventiva e curativa, envolvendo desta forma os diferentes níveis de assistência (Mattos, 2001).

Ao considerar que estes sentidos estão correlacionados, no presente estudo, foca-se mais no segundo sentido de integralidade, que diz respeito à organização dos serviços de saúde, traduzido nas categorias operatórias acesso, vínculo e integração dos serviços.

Vínculo: entendido como a existência de uma fonte regular de atenção e seu uso ao longo do tempo a qual está relacionado aos laços interpessoais 
que se fortalecem entre as pessoas da comunidade e os profissionais de saúde (Ibañez et al., 2006).

Acesso: entendido como a capacidade das pessoas em buscar e obter os serviços necessários no lugar e no momento certo. Vai além dos limites geográficos e envolve questões socioculturais, econômicas e políticas. Diz respeito à interação entre os usuários e os prestadores de serviços e inclui questões organizacionais, que estão relacionadas à disponibilidade de recursos, à acessibilidade geográfica e social e às características da estrutura e processo de prestação de cuidado (Dever, 1988 apud Giovanella, Fleury, 1995).

Integração dos serviços: entendida como a continuidade do atendimento ao usuário, tanto nos diferentes pontos de complexidade da rede de serviços, quanto no mesmo serviço de saúde. Inclui também a capacidade dos serviços em prestar atendimento de forma ininterrupta e coordenada (lbañez et al, 2006).

Segue abaixo quadro síntese das categorias de análise e operatórias do estudo:

Figura 1: Quadro 1 - Categorias de análise e operatórias

\begin{tabular}{|l|l|l|}
\hline $\begin{array}{l}\text { Objeto do } \\
\text { estudo }\end{array}$ & $\begin{array}{l}\text { Categoria de } \\
\text { análise }\end{array}$ & \multicolumn{1}{|c|}{ Categorias operatórias } \\
\hline $\begin{array}{l}\text { Trajetória em } \\
\text { busca por } \\
\text { cuidados em } \\
\text { Saúde de uma } \\
\text { pessoa que vive } \\
\text { com HIV }\end{array}$ & Integralidade & $\begin{array}{l}\text { Acesso: identificação dos serviços } \\
\text { acessados da rede de saúde; identificação } \\
\text { das facilidades, dificuldades e limitações na } \\
\text { busca por cuidado; }\end{array}$ \\
& $\begin{array}{l}\text { Vínculo: critérios de escolha pelo serviço; } \\
\text { local e tempo de acompanhamento dos } \\
\text { problemas e necessidades de saúde }\end{array}$ \\
& $\begin{array}{l}\text { Integração: continuidade do atendimento } \\
\text { no próprio serviço ou entre serviços } \\
\text { acessados }\end{array}$ \\
\hline
\end{tabular}




\subsection{ESTRATÉGIA METODOLÓGICA}

Por meio da fala do usuário, foi utilizada a História de Vida Focal, com mapeamento do percurso da busca por cuidados por meio do Itinerário Terapêutico.

Como estratégia metodológica, o itinerário terapêutico foi escolhido após a realização da primeira revisão bibliográfica, que tinha como objetivo identificar textos que discutissem a avaliação da integralidade nos serviços de saúde. Nesta perspectiva, os textos encontrados apontaram o itinerário terapêutico (IT) como potencial tecnologia avaliativa da integralidade e resolubilidade dos serviços.

O IT tem sido discutido por diversas áreas do saber, como na antropologia, na psicologia, na sociologia e na saúde, assumindo, conforme as respectivas áreas, significados peculiares e até terminologias diferenciadas, tais como: "processos terapêuticos", "caminhos percorridos"; "procura de cuidados em saúde"; "trajetória biográfica"; "peregrinação"; "experiência da enfermidade" (Bellato, Araújo e Castro, 2008).

O termo itinerário terapêutico vem sendo apresentado como recurso que ilustra a busca dos usuários por cuidados, na tentativa de solucionarem seus problemas de saúde, o que favorece a descrição e análise das práticas individuais e socioculturais de saúde (Gerhardt, 2006).

Essa técnica tem sido considerada como uma tecnologia avaliativa, pois possibilita o mapeamento dos serviços que as pessoas buscam em seu adoecimento. $\mathrm{O}$ ordenamento deste percurso permite avaliar os seguintes itens: a manifestação inicial do adoecimento; as agudizações e normalidades; o agravamento da enfermidade ou sua cronificação; as instituições, serviços e profissionais acessados; os encaminhamentos a outros serviços e aos diferentes níveis de atenção (primária, secundária e terciária); os deslocamentos territoriais realizados, bem como as respostas 
obtidas em todos os serviços. Desta forma, o IT favorece discussões sobre a experiência da busca por cuidados, sobre as redes de sustentação e de apoio e sobre a organização formal dos serviços de saúde (Bellato, Araújo e Castro, 2008).

Ao trazer a experiência de adoecimento e busca de cuidados dos usuários dos serviços de saúde, o IT permite retratar os sentidos das práticas dos profissionais para os usuários e como, nas práticas concretas em saúde, é possível haver resolubilidade e integralidade da atenção (Bellato, Araújo e Castro, 2008).

Esta estratégia também propicia que as redes locais de serviços de saúde sejam conhecidas, o que favorece um olhar diferenciado para a organização dos serviços. Assim, é importante apontar que o IT "fornece subsídios para repensar o processo de trabalho, a gestão, o planejamento e a própria construção de saberes e práticas em saúde dos diferentes atores sociais envolvidos no processo" (Gerhardt, Rotoli, Riquinho, 2008).

Por possuir caráter avaliativo, a construção do IT possibilita investigar as mediações construídas nas redes intersticiais que permeiam a organização dos serviços e, desta forma, é possível compreender os dilemas envolvidos, inclusive no trabalho das equipes da ESF (Tavares, Bonet, 2008).

Em geral as discussões sobre IT são realizadas em torno de dois eixos: a perspectiva individual, que enfatiza as escolhas que $o$ indivíduo faz e que determinam seu itinerário; e o eixo relacionado ao meio social e cultural, que determina as possibilidades de escolhas que este indivíduo possa ter. Isoladamente cada eixo não responde totalmente às necessidades dos usuários, necessitando, desta forma, cada vez mais sua articulação (Bellato, Araújo, Castro, 2008).

Tal articulação é necessária tendo em vista a relação tensionada que se estabelece entre as pessoas e as instituições formais de cuidado. 
Instituições estas que estão estruturadas em rede de atenção complexa e hierarquizada e organizadas em modelos com diferentes propostas políticas e administrativas e que, sobretudo, almejam atender as necessidades múltiplas de saúde da população, nas dimensões de promoção, prevenção, reabilitação e cura. Desta forma, não se poderia deixar de considerar as tensões que são produzidas nesses espaços entre os usuários que buscam os serviços de saúde, suas famílias, suas comunidades e os trabalhadores de saúde (Bellato, Araújo, Castro, 2008).

A tensão estabelecida entre os usuários e as instituições de saúde pode ser discutida por duas lógicas, a do usuário e a dos serviços, que, ao serem exploradas, possibilitam um redesenho na configuração dos serviços de saúde. A lógica dos usuários e suas famílias está relacionada à busca por cuidados que eles realizam a partir do recorte de suas necessidades, não se limitando, assim, aos serviços formais de saúde como locais exclusivos desta busca. A lógica dos serviços de saúde é refletida nas práticas profissionais e no modo como os serviços se organizam. Vale lembrar que, no encontro dessas duas lógicas, os serviços de saúde criam normas e rotinas, que moldam e até restringem os profissionais e, ao mesmo tempo, os usuários buscam caminhos que pressionam o que está formalmente estruturado (Bellato, Araújo e Castro, 2008).

Para este estudo foi avaliada a lógica do usuário, considerando que, por esta perspectiva, obtém-se um olhar privilegiado para compreender a organização dos serviços e a oferta de cuidados à saúde. Para tanto, foi realizada imersão na experiência do usuário por meio de sua fala.

Para Minayo (2006, p. 110), pelo caráter subjetivo e social e por sua densidade, a fala é considerada um fato social e é

reveladora de condições estruturais, de sistema de valores, normas e símbolos e ao mesmo tempo, tem a magia de transmitir, por meio de um porta-voz, as representações grupais, em condições históricas, socioeconômicas e culturais específicas. 
Por meio da fala é possível acessar a história de vida, que é um importante instrumento para descoberta, exploração e avaliação de como as pessoas compreendem o passado, de como relacionam a experiência individual ao contexto social, interpretando e dando-lhe significado a partir do presente. Desta forma, a história de vida oferece material para análises sociológicas, descrição de época e possibilita a reflexão e discussão sobre diferentes temas em diversos níveis de abrangência (Minayo, 2006).

Bellato, Araújo e Castro (2008 p. 176) defendem que "o passado reconstruído não é, portanto, refúgio, mas uma fonte de razões para lutar. A memória deixa de ter um caráter de restauração e passa a ser memória geradora de futuro".

Para este estudo, utilizou-se a história de vida tópica, que dá ênfase à determinada etapa ou setor da vida pessoal ou de uma organização. Assim, parte-se não de toda a história de vida do sujeito, mas de um período, ou acontecimento específico da sua vida. Para tanto, realizou-se a entrevista em profundidade, em que o informante é convidado a falar livremente sobre um tema e as perguntas do investigador, quando feitas, buscam dar maior profundidade às reflexões (Minayo, 2006).

Para Bellato et al (2008), a história de vida tópica é denominada História de Vida Focal (HVF), e as autoras destacam-na pelas potencialidades na pesquisa em saúde e enfermagem e na prática avaliativa de serviços de saúde. Elas defendem também que as narrativas encontradas apontam elementos que possibilitam apreender as práticas de cuidado e de gestão que se realizam nos serviços de saúde e de que forma tais serviços atendem aos princípios da integralidade e da resolubilidade. 


\subsection{LOCAL DO ESTUDO}

O estudo foi realizado no distrito do Rio Pequeno, localizado na região Oeste do Município de São Paulo. Este distrito é composto pelas regiões do Butantã, Morumbi, Raposo Tavares e Vila Sônia, cujos serviços de saúde respondem administrativamente à Supervisão Técnica de Saúde do Butantã, que está inserida na Coordenadoria Regional de Saúde Centro-Oeste, da Secretaria Municipal de Saúde de São Paulo, em cogestão com a Fundação Faculdade de Medicina da Universidade de São Paulo. Nesta Supervisão perfaziam, até novembro de 2010, catorze Unidades Básicas de Saúde (UBS), com cinco delas operando na Estratégia Saúde da Família (ESF), totalizando 27 equipes de Saúde da Família.

A escolha pela região deu-se por causa dos projetos de integração ensino, serviço e pesquisa - desenvolvidos na região entre a Escola de Enfermagem da USP e a Fundação Faculdade de Medicina da USP. A presente investigação integra o projeto "Vulnerabilidade da Atenção em HIV/AIDS na Estratégia Saúde da Família". Além disso, a pesquisadora, tendo atuado como enfermeira numa Unidade da região, adquiriu familiaridade dos problemas e necessidades das famílias do território.

Abaixo, segue ilustração da localização da Supervisão Técnica de Saúde do Butantã no município de São Paulo, bem como, na figura seguinte, ilustração dos cinco distritos administrativos. 


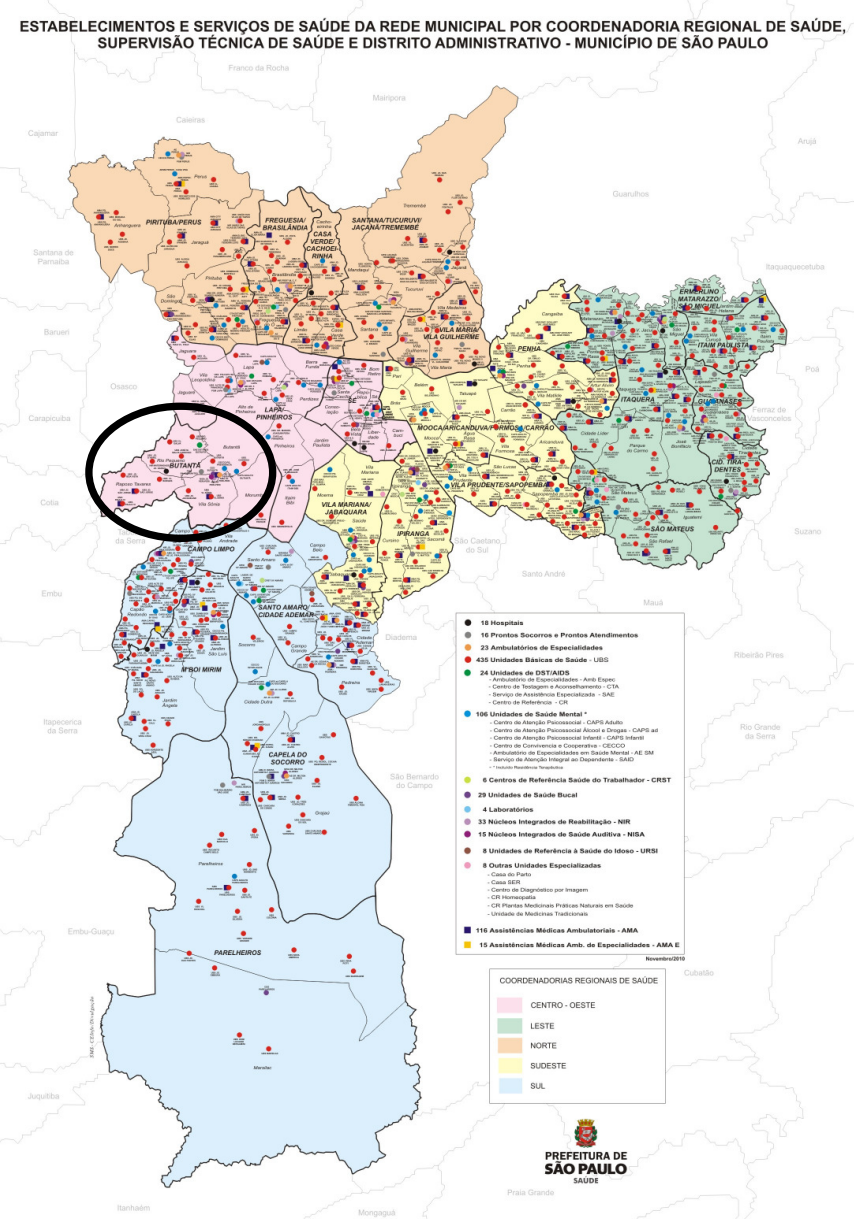

Figura 2: mapa do Município de São Paulo

Fonte: Prefeitura Municipal de São Paulo, 2010c.

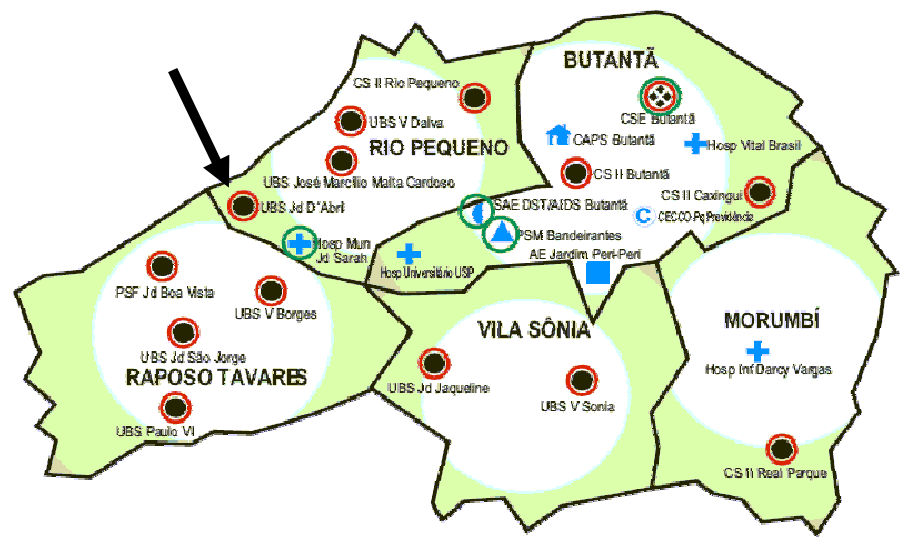

Figura 3: Mapa do Distrito Butantã

Fonte: Prefeitura do Município de São Paulo, 2010c. 
O Distrito Administrativo Rio Pequeno, segundo o IBGE, conta com uma população de 118.459 habitantes (São Paulo, 2010d). Em estudo com base em indicadores sociais do mapa de exclusão social do município, Silva e Fracolli (2007), discutem que os distritos administrativos Rio Pequeno e Raposo Tavares são distritos com área de intensas desigualdades sociais e com níveis precários de qualidade de vida. As autoras apontam que em primeiro lugar o distrito Raposo Tavares, seguido do Rio Pequeno apresentam os piores índices de exclusão/inclusão social na região do Butantã (Silva,Fracolli, 2007).

Em termos de equipamentos de saúde, há no Rio Pequeno um Hospital e Maternidade, Prof Mario Degni- Jardim Sarah; um SAE DST/AIDS de referência e quatro UBS: UBS Rio Pequeno, UBS Vila Dalva, UBS José Marcílio Malta Cardoso e a UBS Jardim d'Abril, esta última de onde parte a realização de presente estudo (São Paulo, 2012b).

Conforme apresentado acima, os moradores na área de abrangência da UBS Jardim D'Abril apresentam características semelhantes ao que foi mostrado no distrito como um todo, com algumas condições e situações mais agravantes em termos de condições de vida, tais como habitação e saneamento precários e violência. Nesta área estão inseridas áreas de invasões e um Cingapura. Localizadas no mesmo território, há populações em melhores condições, em condomínios residenciais de altos valores imobiliários, conhecidos como Parque dos Príncipes.

A unidade foi inaugurada em 1985. Desde 2001 opera na Estratégia Saúde da Família. Sua área de abrangência compreende os bairros Parque dos Príncipes, Jardim D'Abril e Jardim do Lago. A Fundação Faculdade de Medicina é parceira na cogestão desta unidade e das demais da Região do Butantã onde há equipes de saúde da família.

A unidade conta com quatro equipes de saúde da família (Equipes Amarela, Azul, Verde e Vermelha), que em conjunto atendem 3.552 famílias cadastradas, o que corresponde a 12.045 pessoas, conforme dados 
fornecidos pela unidade em seis de outubro de 2011. Além das famílias e pessoas cadastradas, a unidade atende também usuários não cadastrados, mas em regime de pronto atendimento, no que se refere a queixas com resolubilidade neste nível de complexidade.

Com diferenças na forma de organização de suas atividades, todas as equipes de saúde da família seguem as diretrizes e ações orientadas pela Secretaria da Saúde e da Fundação Faculdade de Medicina, prioritariamente na Atenção à saúde da criança, mulher, adulto e idoso.

Com relação à atenção de doenças sexualmente transmissíveis e HIV/AIDS, as ações de prevenção concentram-se na oferta de preservativos e de exames laboratoriais para detecção do HIV, realização de orientação sorológica na entrega dos resultados dos exames solicitados, particularmente como protocolo a ser seguido no acompanhamento do prénatal. Também esporadicamente são realizadas ações educativas no grupo de Planejamento Familiar e realizada abordagem individual da temática em consultas agendadas, quando o profissional de saúde percebe maior vulnerabilidade ao HIV/AIDS e quando é solicitado pelo usuário - dados fornecidos pela gerência da unidade.

Quando diagnosticados na unidade, os usuários soropositivos são encaminhados para acompanhamento da infecção no Serviço de Assistência Especializada em DST/AIDS Butantã (SAE-Butantã), localizado no Distrito Butantã. 


\title{
3.5. IDENTIFICAÇÃO DO SUJEITO DE PESQUISA E PROCEDIMENTOS DA COLETA DE DADOS
}

\begin{abstract}
Tendo sido aprovado pelo Comitê de Ética em Pesquisa, primeiramente $\mathrm{o}$ projeto foi apresentado em reunião técnica para enfermeiros e médicos da unidade para esclarecimento dos objetivos e dúvidas.
\end{abstract}

O sujeito da pesquisa foi uma usuária cadastrada na Estratégia de Saúde da Família da UBS Jardim D’Abril, residente na área de abrangência de uma das equipes da ESF desta unidade. Para se chegar à usuária, contou-se com a colaboração de médicos e enfermeiros das equipes de saúde da família, bem como a enfermeira responsável pela vigilância em saúde da respectiva unidade. Buscando garantir o anonimato da pessoa que vive com HIV, o convite para participar da pesquisa foi solicitado ao membro da equipe que compartilha o diagnóstico com a usuária.

A escolha pela Atenção Básica como local de acesso ao sujeito de pesquisa esteve relacionada ao interesse de contatar uma pessoa vivendo com HIV e que apresentasse vínculo com a ESF, a fim de que esse critério garantisse, para a discussão, a existência deste nível de atenção nos serviços acessados em sua busca por cuidados. Caso contrário, correr-se-ia o risco de a UBS estar apenas citada na trajetória, sem propiciar discussões mais profundas acerca da contribuição deste nível de complexidade no enfrentamento da epidemia da aids.

A escolha do sujeito de pesquisa obedeceu aos seguintes critérios: adulto (maior de dezoito anos), residente na área de abrangência da ESF, ser bom informante (sem problemas de dicção e sem transtorno mental) e ser do sexo feminino, tendo em vista a feminização da epidemia ao longo dos anos e pela possibilidade de se discutir o acesso aos serviços em diferentes contextos de assistência. 
Foram identificados no total doze usuários soropositivos nas quatro equipes, sendo seis mulheres. Após consulta destes seis prontuários, seus casos foram discutidos com os profissionais que as conheciam, com a finalidade de identificar aquelas que poderiam participar da pesquisa.

Em uma das equipes, a usuária não foi selecionada, dado que nunca havia feito acompanhamento do HIV/AIDS na unidade; não havia citação sobre a infecção ao HIV no prontuário e, segundo o profissional que a conhecia, ela somente recorria à unidade quando havia queixas agudas, eventos não necessariamente associados ao HIV/AIDS.

$\mathrm{Na}$ segunda equipe foram identificadas três mulheres, duas destas, mãe e filha, envolvendo a transmissão vertical. Após leitura dos prontuários e discussão com a equipe, foi selecionada uma usuária do serviço de saúde de 39 anos, com diagnóstico recente de HIV e que vinha sendo acompanhada na UBS desde seu diagnóstico de infecção. A esta foi explicado o objetivo da pesquisa e, embora tivesse consentido inicialmente, informou que não gostaria de participar da pesquisa, justificando compromissos e tempo indisponível. Apesar de garantir o sigilo das informações e os cuidados em relação ao anonimato, optou em não participar da pesquisa. Na terceira equipe, foi identificada uma usuária, porém não foi possível encontrá-la após vários contatos realizados.

Na quarta equipe foi identificada uma usuária que teve o diagnóstico de HIV realizado durante o pré-natal. Encaminhada ao SAE, a médica da equipe de Saúde da Família fez vários contatos para não perder o vínculo com a usuária. Contudo, a usuária comunicou à equipe não querer continuar o acompanhamento na UBS por conhecer muitas pessoas do local e temer a quebra do sigilo do diagnóstico. Entrando em contato com ela, aceitou participar do estudo, desde que se garantisse o sigilo das informações, o que foi assegurado pela pesquisadora. Para não identificá-la, seu nome e de outras pessoas foram substituídos por pseudônimos, exercendo desta forma, a confidencialidade e o anonimato da usuária, identificada como Sofia. 
Para a realização da entrevista em profundidade, foram realizados três encontros com Sofia. Os encontros ocorreram em sua residência, em horários agendados por ela. Com seu consentimento, as entrevistas foram gravadas e posteriormente transcritas na íntegra.

No primeiro encontro, com duração de 46 minutos, os procedimentos da pesquisa foram detalhados, com ênfase na garantia do processo ético e apresentação do Termo de Consentimento Livre e Esclarecido. Após assinatura do termo, a usuária foi convidada a falar livremente sobre o percurso do adoecimento, desde os primeiros sintomas até o momento atual, tendo como ponto de partida a questão norteadora:

"Conte-me como se deu a busca por atendimento desde os primeiros sintomas do diagnóstico de HIV até o momento atual."

O segundo encontro, com duração de 54 minutos, foi realizado após três dias deste contato inicial. Já com este encontro transcrito, no segundo momento buscou-se resgatar o que não havia sido abordado anteriormente, tendo em vista as categorias operatórias. No último encontro, com duração de 1 hora e 21 minutos, realizado após cinco dias do segundo, foram aprofundadas questões já abordadas e dúvidas que não haviam sido exploradas anteriormente.

As falas foram gravadas e transcritas pela própria pesquisadora imediatamente após as entrevistas. Também foram registradas em um diário de campo anotações sobre as percepções e vivências pessoais do pesquisador.

Além da entrevista com a usuária, foram obtidos dados e informações dos prontuários da UBS e do SAE-Butantã, como complemento ao material empírico obtido nas entrevistas.

O período de coleta de dados compreendeu os dias entre doze de agosto e onze de setembro de 2011. 


\subsection{ANÁLISE DOS DADOS}

Os resultados obtidos foram analisados pela Análise de Discurso proposta por Fiorin e Savioli (1991), que está fundamentada na Teoria de Greimás ou Teoria da Geração de Sentidos do Texto que permite a depreensão de frases temáticas (Fiorin, 1989). Foi utilizada uma adaptação da técnica, pois durante a desconstrução e reconstrução da estrutura narrativa surgiram vários temas geradores de sentido e não foi possível contemplar todos os sentidos subjacentes emergidos da narrativa, optandose apenas aos temas relacionados aos objetivos do trabalho e às categorias operatórias para a o delineamento da trajetória.

A Análise de Discurso considera que a linguagem possui materialidade simbólica e significativa e que a língua enquanto trabalho simbólico que faz e dá sentido, expressa as relações do homem e sua história. A Análise de Discurso considera que por meio da linguagem o homem transforma a realidade em que vive e a si mesmo, marcando e modificando sua historicidade. Assim, extrapola a língua como sistema fechado nela mesma e impõem a ideia de discurso, que é um objeto sociohistórico. Desta forma, a Análise de Discurso busca apreender como a ideologia se materializa no discurso e como o discurso se materializa na língua, a fim de compreender como o sujeito influenciado pela ideologia de seu tempo e lugar social utiliza a língua para significar-se (Silva, 2005).

Ao partir da concepção de discurso que considera então os contextos sociais e a historicidade, na análise do discurso buscou-se identificar figuras presentes nas falas (elementos concretos) e os temas (elementos abstratos). As figuras, segundo Fiorin e Savioli (1991), são palavras ou expressões referidas à fala concreta (substantivos concretos, verbos que indicam atividades físicas e adjetivos que expressam qualidades físicas). Já os temas são palavras ou expressões que contêm elementos que organizam, categorizam e ordenam a realidade percebida. No texto, todos estes 
elementos estão relacionados, e o que dá sentido às figuras é um tema. Desta forma, encontrar o sentido de figuras encadeadas é achar o tema subjacente a elas. Os temas evidenciam os sentidos e os significados de cada ação contida no discurso.

Desta forma, na análise da entrevista, procedeu-se à sua desconstrução e reconstrução, partindo da estrutura narrativa, ou seja, do concreto, decodificando-o na estrutura de sentidos subjacentes ao texto, constituída das frases temáticas. Os subtemas foram agrupados e constituíram um corpus temático. A análise dos discursos permitiu identificar as representações dos depoentes, com base no discurso textual.

Duas principais unidades foram encontradas: percurso em busca de cuidados e fontes de apoio e sustentação. Na unidade temática "percurso em busca de cuidados" foram agrupadas frases temáticas que retratassem a experiência da usuária em busca de cuidados, no que se diz respeito ao desafio de viver com o HIV, ao acesso aos serviços de saúde e às práticas de saúde ocorridas em todo o percurso. $E$ as frases temáticas da segunda unidade constituíram-se de frases que refletissem os suportes recebidos em toda trajetória, sejam eles provenientes diretamente da família, amiga, profissionais de saúde e lgreja ou, indiretamente, pelo trabalho e estudo. As frases agrupadas segundo suas unidades temáticas constam no Apêndice 3. 


\subsection{ASPECTOS ÉTICOS}

O projeto foi submetido à aprovação pelo Comitê de Ética em Pesquisa da Escola de Enfermagem da USP e pelo Comitê de Ética da Secretaria Municipal da Saúde de São Paulo (Anexo 9.1).

A usuária, no estudo identificada como Sofia, foi entrevistada após aceitação para participar da pesquisa e após assinatura do Termo de Consentimento Livre Esclarecido, obedecendo aos procedimentos de pesquisa exigidos pela Resolução n CNS196/96 (Brasil, 1996).

Com a aprovação dos Comitês de Ética em Pesquisa da Escola de Enfermagem da USP e da Secretaria Municipal da Saúde de São Paulo foi solicitada autorização à Supervisão Técnica de Saúde do Butantã e à responsável da área de pesquisa da Fundação Faculdade de Medicina. Posteriormente, a realização da pesquisa foi autorizada pela gerente da UBS Jardim D'Abril. 
4. RESULTADOS 


\section{O PERCURSO EMPREENDIDO EM BUSCA POR CUIDADOS E AS FONTES DE SUSTENTAÇÃO E APOIO}

Neste capítulo busca-se apresentar os resultados após avaliação exaustiva das narrativas e, para tanto, inicialmente apresenta-se o percurso de Sofia em busca de cuidados, no que se diz respeito ao acesso aos serviços e as práticas de cuidado em saúde ocorridas durante sua trajetória. Em seguida, são apresentadas as fontes de apoio e sustentação, importantes delineadoras nesta busca por cuidados.

\subsection{O PERCURSO EM BUSCA DE CUIDADOS APÓS DIAGNÓSTICO DE HIV: ACESSO AOS SERVIÇOS E AS PRÁTICAS DE CUIDADO EM SAÚDE}

Sofia, de cor branca, tinha 30 anos quando da coleta de dados em 2011. Procedente de Osasco e residente no município de São Paulo há catorze anos, no Rio Pequeno, residia com sua filha Luana, de nove meses e sua mãe, dona Margarida, de 62 anos. Na época da entrevista, Sofia cursava o ensino superior em pedagogia e trabalhava na área da educação, como monitora infantil. Havia acabado de retornar ao trabalho, após licença maternidade e assim, sua vida era preenchida por muitas atividades, pois estudava no período da manhã e trabalhava no período vespertino. À noite, reservava o tempo para cuidar de sua filha e sua mãe, de forma que o tempo destinado ao cuidado de si era restrito.

Desde a descoberta do diagnóstico, em trinta de junho de 2010, sua vida vinha sofrendo grandes transformações, pois conviver com o HIV vinha sendo um grande desafio para Sofia, desde as adaptações de horários para 
as medicações, à organização de sua vida para as frequentes consultas médicas e, principalmente por conviver com o medo de revelação do seu diagnóstico, pois temia intensamente a rejeição social.

O marco para Sofia é 2009, período em que acredita ter manifestado os primeiros sintomas relacionados ao HIV/AIDS. Este ano é marcante para Sofia, pois recorda que realizaria uma cirurgia de desvio de septo - ocasião em que realizou vários exames pré-cirúrgicos em serviço de convênio médico privado, acreditando que incluía sorologia ao HIV, com resultado negativo. Porém não chegou a realizar a cirurgia devido a não autorização do convênio. Após realização destes exames, Sofia enfatiza em sua trajetória, a morte abrupta de seu pai, ocasionada por um acidente vascular cerebral. Relaciona a este evento o início da manifestação de quadro alérgico e gripal, que acredita ter sido sintomas da infecção do HIV. Sofia relata que devido ao intenso sofrimento com a perda, acredita que seu sistema imunológico teve uma recaída, o que propiciou o provável início dos sintomas relacionados ao HIV. Ainda em 2009, aproximadamente quatro meses após os exames pré-operatórios, procurou um Pronto Socorro privado em três ocasiões, onde recebeu tratamento direcionado a este quadro inespecífico, com melhora dos sinais e sintomas.

"eu senti... a garganta que não sarava, a garganta inflamou, muita febre, eu sentia...não tinha o que passava essa febre e daqui a pouco, olha a febre novamente. Muito cansaço, o corpo tava parecendo que eu tinha levado uma surra, parece uma gripe, mas não era uma gripe, não tava escorrimento nada, parecia uma gripe, quando você fica muito gripada e meio que te derruba..."

"aí apareceu as alergias no corpo, aí eu falei: que que tem a ver essas alergias?" 
Não havia naquele momento suspeita de que estes sintomas pudessem estar associados à infecção pelo HIV, tanto de Sofia quanto dos serviços de saúde que procurou. Fazendo uma retrospectiva, indaga se já não teriam sido estas as primeiras manifestações e se poderia ter se beneficiado em termos de tratamento, com o diagnóstico realizado de forma mais precoce. Mais ainda, questiona sobre a competência do serviço privado para realizar o diagnóstico de HIV.

“.... eu não sabia o que era, só senti os sintomas, que pelo menos foi depois que eu descobri o que acontecia com a pessoa quando o vírus entrava, né, no corpo da gente, que dava umas reações fortes, né, que eu lembrei que eu tive uma fase muito difícil mesmo, eu achei que era uma dor de garganta normal, não tinha remédio...."

"eu fui duas, três vezes ao médico, plano de saúde, não estava no SUS, e eles não diagnosticaram nada, nem pensaram, talvez eu teria levado um susto, mas talvez eles teria me ajudado"

"talvez se eu já tivesse tomado o coquetel teria me ajudado naquele momento..."

Ao retroceder sua trajetória antes destes sintomas e buscar informações sobre o acesso de Sofia na Atenção Básica, foram encontradas anotações em seu prontuário de quando criança na UBS Jardim d'Abril, sendo o primeiro registro de atendimento com a idade de 7 anos de vida.

Quando adolescente e na fase adulta, os atendimentos anotados estavam voltados predominantemente para queixas agudas, tais como, gastroenterite aguda, escabiose, rinite alérgica, bronquite asmatiforme e consultas ginecológicas, com solicitação de contraceptivos e citologia 
oncótica. Quando questionada se havia recebido alguma orientação sobre DST/AIDS na UBS, Sofia relata que não recebeu abordagem direta deste assunto, nem na consulta ginecológica.

"Só cartaz mesmo. A gente via alguns cartaz mesmo. E tinha um vídeo. Porque tem uma televisão lá na sala de recepção, que fala de algumas doenças, diabetes, é, HIV,é, várias outras doenças. Hepatite, né? Até alguns do Dráuzio Varella, mas de comentar assim, de boca, não."

Segundo sua fala, antes do diagnóstico de HIV, em 2010, desconhecia o que era a infecção e seu desenvolvimento, e não se percebia vulnerável ao HIV. Para Sofia, a epidemia da aids estava associada à frequência de relação sexual com vários parceiros diferentes.

"Nossa, mas nunca passa na sua cabeça que vai acontecer isso com você, nunca passa, você não acredita, com você não! Entendeu? Então, pra que que eu vou usar (preservativo)? Eu não estou saindo por aí, eu não sou promíscua, é uma pessoa que eu estou morando..."

"eu realmente achava que era muito ligado à promiscuidade, tipo: bem feito, não se cuidou, hoje mudou muito...."

Nas narrativas, Sofia indica necessidade de maior acesso às informações sobre HIV/AIDS, para toda a população, para que possam ser minimizados, o desconhecimento e o preconceito, o que poderia interferir na 
vulnerabilidade à infecção e ao adoecimento pelo HIV. Ao mesmo tempo, afirma que o País não está preparado para lidar com o problema.

"Talvez a mídia pudesse dar uma mudada...Também não tem como expor ainda,....o Brasil não tem capacidade ainda, não tem estrutura".

"E o pior, é que tem muita gente que não sabe...E aí vai ficando de forma que vai ter que saber da pior forma possível, quando tiver já muito ruim...E aí, muitas pessoas têm dúvidas e não querem buscar mesmo, né.."

A possibilidade de infecção pelo HIV estava distante de Sofia antes do diagnóstico. Em seus relacionamentos afetivos e sexuais, por exemplo, não fazia uso do preservativo, tornando-a vulnerável não só às doenças sexualmente transmissíveis como à gravidez.

Retornando ao ano de 2009, Sofia refere que logo após o falecimento de seu pai, teve seu relacionamento amoroso rompido e que após três meses, no final de 2009, conheceu o pai de sua filha, engravidando provavelmente no final de abril ou início de maio de 2010.

Não contando mais com a assistência privada, ao suspeitar de possível gravidez, Sofia procurou a UBS Jardim d'Abril. Confirmada a gravidez, a primeira consulta de pré-natal foi realizada com enfermeira e, analisando sua narrativa, esta parece ter seguido o protocolo de atendimento de gestantes da Secretaria Municipal da Saúde de São Paulo. Sofia destaca a qualidade do atendimento, em termos de exames pedidos e rapidez na marcação da consulta subsequente. 
"fui muito bem atendida, ela me pediu todos os exames, 0 hemograma completo, o de HIV, pediu vários exames, né, acho que exatamente, não, foi hemograma, esse, do teste de HIV, enfim, os básicos mesmo".

"eles já encaminharam para a doutora, isso eu achei muito legal, porque eu nem precisei assim, de certa forma eles já me encaminharam pra eu começar passar com a doutora"

Rotineiramente, a UBS após a consulta inicial com o enfermeiro, agenda a primeira consulta médica a tempo de se ter os resultados dos exames do primeiro trimestre gestacional. Quando necessário, esta primeira consulta médica é antecipada, especialmente na identificação de exames laboratoriais alterados. Assim, a UBS tendo identificado no exame de Sofia resultado positivo para o HIV, antecipou a data de realização da consulta de retorno com a médica. Sofia demonstra em sua fala estranhamento e desconfiança.

"ela antecipou essa consulta e aí eu achei estranho, por que antecipar? Sendo que eu tinha exames, ahhh,"

Sofia relata o impacto ao receber o diagnóstico de HIV em consulta com a médica.

"Foi no posto, foi exatamente com a Dra Carla, quando ela me chamou e foi um dos piores dias da minha vida, não vou mentir...foi a perca da minha vida assim, naquele momento, ai, eu achei que eu não ia ter nada mais, que eu...planos, eu vi tudo desmoronar na minha frente ... e aquilo foi desmoronando de tal 
forma que até acho que a Dra Carla falaria melhor, mas eu tive uma crise muito grande, eu não conseguia levantar do chão, eu não conseguia, eu queria gritar,..., eu não conseguia sair da porta, eu estava com pânico de alguém me olhar, né?"

Traduzindo seu relato, apresentou reações de desespero, angústia, sentimentos de perdas de planos e de sua identidade diante do diagnóstico tão ameaçador. $\mathrm{Na}$ ocasião havia sido recentemente aprovada em um desejado concurso público e, com o diagnóstico, receou perdê-lo, o que representava para ela destruição de sonhos conquistados. Neste momento de intensa desestruturação emocional, a médica da equipe de saúde da família teve importante papel no acolhimento de suas angústias, conforme pôde-se apreender de seu relato.

Sofia destaca que tal apoio não esteve restrito ao fornecimento de informações técnicas, pois naquele momento não estava em condições de receber tais orientações, mas sim ao fato de simplesmente estar ao seu lado, oferecendo-lhe o que mais precisava naquele momento: sentir-se acolhida.

"ela foi uma amiga, assim, ela foi muito maravilhosa, porque ela largou tudo o que ela teve que fazer, pra ficar comigo, ela largou consultas, ela viu meu desespero..."

Mais calma, Sofia recebeu explicações da médica que ela seria encaminhada ao Serviço de Assistência Especializada (SAE) em HIV/AIDS, para acompanhamento mais específico. No mesmo dia, foi realizado contato com o SAE de referência, por comunicação verbal, via telefone, avisando 
sobre o encaminhamento da UBS. Além disso, foi preenchido um formulário escrito de referência a ser acompanhado com a usuária.

Segundo seu relato, a UBS chegou a acionar o pedido de transporte de ambulância, para o trajeto da UBS ao SAE, mediante o risco de acidente devido ao estado emocional de Sofia estar bastante abalado. Mas foi negado veementemente por Sofia, por medo de exposição, de que as pessoas soubessem do seu diagnóstico. Após melhora de seu quadro emocional, no mesmo dia ela mesma foi de transporte próprio até o SAE.

Até este momento sua trajetória em busca de cuidados de saúde pode ser considerada como inespecífica e, desta forma, os serviços acessados seguiam uma lógica de acompanhamento descontínuo, já que Sofia buscava atendimentos pontuais e esporádicos. A partir do diagnóstico de HIV, Sofia iniciou uma busca por cuidados direcionada e com foco em HIV/AIDS.

Com a comunicação realizada pela UBS informando o caso, o SAE já a aguardava para seu acolhimento no serviço.

"Eu fui atendida pelo assistente social, pelo psiquiatra...o psiquiatra me deu uma medicação, porque ele viu que se eu continuasse daquele jeito ele ia ter que internar, aí eu tive que começar a tentar voltar, porque eu não conseguia voltar ao que eu era, eu estava descontrolada"

"E lá, eles me apoiaram, nossa, sei que acho que até passaram de horário e ficaram do meu lado ali, tentando achar palavras, nesse momento não adianta falar, eu acho, eu não sei, eu não posso generalizar, mas comigo não adiantava falar, não tinha palavra que me consolasse, não tinha palavra que....não adianta. Mas a pessoa estava ali, ela estava se mostrando, que ela estava 
do meu lado, entendeu, talvez não com palavras, mas ela está ali, entendeu, sei lá o que acontecesse"

Avalia-se que este momento inicial no SAE foi bastante importante para Sofia e para a formação de vínculo entre usuário e serviço, o que favoreceu seu posterior retorno e sua adesão ao tratamento ao longo do tempo.

A primeira pessoa com quem compartilhou a informação sobre seu diagnóstico foi uma amiga, buscando encontrar conforto e incentivo para seguir sua vida, bem como para retornar a busca por cuidados de saúde. Temia a revelação do diagnóstico para sua família, abrindo esta informação, primeiramente ao pai da criança, que se afastou completamente e, posteriormente, para seu irmão mais velho, suas cunhadas, irmão mais novo e por último sua mãe.

Mais fortalecida emocionalmente, com o apoio da família e da amiga, resolveu dar início ao tratamento e acompanhamento para enfrentar possível adoecimento por aids e para evitar a transmissão vertical.

No SAE, segundo as narrativas, foram oferecidos atendimentos com infectologista, ginecologista, assistente social, terapeuta ocupacional, pediatra, enfermagem, psicóloga, psiquiatra, nutricionista, odontologista, bem como atendimento em grupo, como grupo de gestante e grupo de trabalhos manuais, conforme consta em sua fala:

"psicóloga, pelo psiquiatra, pela nutricionista, quer ver, tem mais alguém...tem a infecto, que é uma maravilha de mulher, nossa, muito legal, muito mesmo. Nossa, eles explicam tudo! Nossa, você é melhor atendida numa situação dessa do que em outra...Sabe, dentista, nossa, quando que você chega no SUS e 
marca dentista assim, ó? E eles fazem todo seu tratamento. Tem dentista, tem a nutricionista, teve ah, ginecologista, aí é tudo com eles, tudo tudo".

Para facilidade da comunicação no SAE e registro dos atendimentos, as anotações eram realizadas em prontuário, que inclusive era disponível em todas as consultas. Sofia entende que este era um instrumento de comunicação entre os profissionais.

"tem um prontuário. Com todos que eu passo vai pro mesmo prontuário. Então qualquer dúvida eles já...sabe, consultam o próprio prontuário"

"lá dentro com eles, era tudo muito anotado, quando eu tava com a minha pasta, o que um marcava o outro lia".

Segundo sua fala, Sofia avaliou de forma positiva a atuação dos profissionais do SAE, que a acolheram de forma respeitosa e segura em relação às condutas. Alguns se destacaram pelo vínculo firmado, como com a médica infectologista. Sofia enfatizou que este vínculo foi fortalecido justamente porque se sentiu acolhida, pois suas angústias, ansiedades e toda sua história de vida eram ouvidas pacientemente.

O vínculo estabelecido tratou da satisfação de necessidades que extrapolavam o âmbito biológico, na centralidade dos exames e condução do tratamento da infecção. A qualidade destacada foi a de saberem ouvir o que era de muito importante para a usuária.

Em contrapartida, nas narrativas não se lembrou de citar a assistência da enfermagem. Quando questionada, referiu que teve contatos 
esporádicos, tais como na realização de procedimentos pela auxiliar de enfermagem, como coleta de exame laboratorial, sem qualificar como se deu esta assistência. Citou a realização de visita domiciliar de puerpério, com participação da enfermagem, em conjunto com a terapeuta ocupacional, sem distinção sobre quais foram os profissionais de enfermagem envolvidos enfermeiro, auxiliar ou técnico de enfermagem e da mesma forma, não fez menção da qualidade do cuidado oferecido.

No SAE as consultas de pré-natal foram realizadas pelo médico, não havendo consultas marcadas com o enfermeiro. As orientações sobre os cuidados em relação à amamentação, um cuidado de saúde tradicionalmente realizado pela enfermagem, foram feitas pelo profissional médico, segundo Sofia.

Durante o acompanhamento da gestação no $\mathrm{SAE}$, em relação às ações de prevenção para evitar a transmissão vertical, Sofia recebeu o tratamento com antirretrovirais durante todo o pré-natal e participou do grupo de gestante realizado no serviço. Durante a gestação relata ter seguido as recomendações, avaliando ter sido muito boa sua adesão ao tratamento.

$\mathrm{Na}$ programação para o parto recebeu o kit com medicações antirretrovirais para o bebê, para ela e para inibição da lactação a ser levado à maternidade. No SAE, recebeu as orientações sobre: os sinais de parto; quando e como procurar a maternidade; e a importância de levar consigo o kit e o cartão de pré-natal.

Foi inserida no Programa Mãe Paulistana, implantado em 2006 no município de São Paulo, cujo objetivo é assistir a gestante durante o ciclo de gravidez, desde o pré-natal, parto, puerpério, até o primeiro ano de vida do bebê. Além do protocolo de acompanhamento e controle clínico do pré-natal, o programa garante a gratuidade de transporte municipal para as consultas e oferece um enxoval básico para o recém-nascido (São Paulo, 2006). 
Em seu relato, Sofia não identificou comunicação do SAE com outros serviços de saúde, como os centros de especialidades a que foi encaminhada, por exemplo, oftalmologia e dermatologia e mesmo com a maternidade. Nas falas há indicações de que em algumas situações houve falta mesmo de comunicação, denotando descontinuidade da assistência.

Um exemplo lembrado por Sofia diz respeito ao cartão de pré-natal que fora preenchido no SAE. Este constitui uma ferramenta de informação sobre a gestação e funciona, em princípio, como importante meio de articulação entre os serviços responsáveis pelo acompanhamento da gestante e hospitais de referência ao parto. Nele há o registro das principais informações sobre o pré-natal que a usuária deve portar consigo quando vai à maternidade, como anotações do nível pressórico, peso, altura uterina, batimentos cardiofetais, movimentos fetais, intercorrências na gestação, além dos registros dos resultados de exames laboratoriais realizados, incluindo sorologias.

Entretanto, Sofia relata que, quando procurou a maternidade, os profissionais desconheciam seu diagnóstico de HIV por não terem lido esta informação no cartão de pré-natal. Segundo ela, caso tivessem atentado a isto, evitaria ter que se expor, evitando assim seu constrangimento. Mais ainda, a informação sobre seu diagnóstico interferiu na conduta dos profissionais em relação à antecipação do parto, após ela própria ter indicado esta informação.

"Então quando eu cheguei, pra mim, automaticamente o médico ia olhar isso. Então eu não vou chegar lá falando. A gente não gosta. Ele que olhe. Tá uma informação ali pra ele. Aquilo ali serve pra que? Não é pra informar?"

"Aí eu abri o cartão e falei assim: isso daqui tem alguma coisa a ver com o meu bebê só ter 2,400kg??? Ele não olhou o cartão e 
perguntou: o que? Aí eu tive que falar. O senhor tá vendo que eu sou reagente??? Ele arregalou o zóião e nisso, eu já tinha passado com outra médica, que também não viu... Aí o médico chegou, arregalou um zóião e disse: nossa, tem tudo a ver, você já vai entrar pro parto. Quer dizer, aí matou, né? Porque eu já estava indo pra casa, eu só estava preocupada com o peso...Aí ele falou, vai ser cesárea..."

Este exemplo é um alerta. A desatenção na leitura do cartão de acompanhamento de pré-natal mostra que este meio instituído de comunicação pode não estar sendo efetivo, portanto, acarretando entraves na continuidade do cuidado nos diversos pontos da rede.

Identifica-se no discurso de Sofia desatenção dos profissionais da maternidade em relação à recomendação quanto ao antirretroviral do kit levado pela usuária. Este kit deveria ser oferecido nas duas primeiras horas de vida do recém-nascido, preferencialmente na primeira, conforme orienta o protocolo de transmissão vertical (Brasil, 2003). Ciente desta recomendação, segundo avalia, houve atraso na sua administração.

Sofia recorda de outra situação relacionada à demora dos profissionais da maternidade na efetivação das recomendações contidas no protocolo de prevenção da transmissão vertical.

Por ser soropositiva e ter o aleitamento materno contraindicado, a maternidade deve instituir o leite artificial ao recém-nascido (Brasil, 2003). Sofia lembra-se de sua insatisfação no atraso da oferta deste para seu bebê.

"se bem que era (para medicarem) na primeira hora,(e) a medicação chegou só duas horas depois. Porque se não me engano o AZT era na primeira hora. E foi dado duas horas depois. 
E eu fiquei em estado de choque, tinha que ir lá toda hora pedir o leite... ir toda hora lá pedir..."

"eu tive que dar leite no copinho pro meu bebê... Só que muitas vezes o leite atrasava, porque é raro quem não tá amamentando, porque eles incentivavam tanto a amamentação, e os outros? ... E o leite atrasava, elas não deixam mamadeira também. Tudo pelo copo. Aí eles te dão uma seringa, a gente dá com seringa pro bebê ... E atrasava, sabe."

"Primeiro, o leite atrasava, no copinho. A menina ficava gritando, aí eu ficava: cadê o leite dessa menina? Eu quase pedia pra entrar leite escondido pra eu dar pra neném...Tá certo que vinha em dosagens pequenas, mas a médica já tinha falado que aumentou a dose e não veio com a dose aumentada. Essa menina gritava de fome. Sendo que médica já tinha colocado no papel que podia aumentar a dose. Eu tinha que ficar esperando a médica no outro dia pra falar. Pra ela enfatizar que já tinham aumentado a dose."

Nesta última narrativa, Sofia identifica comunicação truncada e descontinuidade do cuidado, quando confronta as orientações da prescrição médica com a forma com que vinha sendo efetivada, possivelmente pela enfermagem, avaliando que estas não estavam sendo seguidas.

Sofia percebe que há diferenças na atenção realizada no período diurno e noturno na maternidade. Demonstrou-se extremamente insatisfeita com os profissionais do período noturno, que não atenderam suas expectativas. Até exaltou o tom da fala durante a entrevista quando se lembrou dos acontecimentos. 
"Eu acho que é assim, claro que ela tem outras obrigações, tinha um monte de coisa pra fazer, mas a gente ali é humano! ... Em prol da criança, em nenhum momento não foi nenhuma lá pelo menos pra ver o que que estava acontecendo. Talvez uma palavra, sei lá, qualquer coisa! .... Durante o dia era bom.

"(de manhã) Parece que os horários eram sempre cumpridos..."

Ainda na maternidade, desconhecia sobre a necessidade de enfaixamento compressivo das mamas para inibição da lactação, situação que resultou ansiedade, desconforto e constrangimento perante outras usuárias.

"elas me enfaixavam, meu peito...Por causa do leite, se saísse leite. Aí eu ficava com aquela faixa horrível no peito, e com aquele meu jaleco aberto, todo mundo via as faixas no meu seio, sabe?... Ai que coisa, mas não ia molhar se saísse? Aí eu iria falar, olha, tá saindo leite. Era uma baita faixa imensa no peito da gente. Meu, e aí, sabe, tinha gente que olhava assim, e eu não, deve ter gente que deve ter se tocado. Foi muito indiscreto..."

Subjaz à narrativa o medo de que outras mulheres questionassem a interrupção da lactação, suscitando suspeita em relação ao diagnóstico de HIV, situação não atentada pela equipe de enfermagem, responsável pelo enfaixamento.

Sobre a enfermagem na atenção ao puerpério imediato, Sofia indicou que esperava receber especial atenção quanto à privacidade da informação sobre seu diagnóstico. Segundo se extrai da narrativa abaixo, houve situações em que teve medo que a enfermagem abrisse a informação sobre 
seu diagnóstico. Sofia percebeu que alguns profissionais da enfermagem faziam suas tarefas parecendo desconhecer a relação com o diagnóstico de HIV.

\begin{abstract}
"Ai, eu acho que eu queria que elas tivessem maior discrição, talvez...Eu sei que elas têm muito trabalho lá, sabe, não sou só eu, não é um particular, é muuuita gente entrando e saindo ... Eu tinha que ficar toda hora entrando em estado de choque pra cada enfermeira nova que tinha. Que eu tava morrendo de medo de ela me expor...(eu queria) que elas já soubessem. Porque de certa forma elas tinham que me trazer a medicação, trazer o leitinho da menina. E por que elas têm que trazer o leite? Porque eu não posso amamentar. Então elas têm que saber!!! Entendeu? Só que elas têm que ser discretas!!!"
\end{abstract}

Após o parto, Sofia recebeu visita domiciliária de puerpério da equipe do SAE. Nesta visita, recebeu orientações da enfermagem (sem distinguir se era enfermeira, técnica ou auxiliar) e da terapeuta ocupacional, sobre cuidados com o recém nascido e os pontos de cesárea.

A preocupação em relação ao conhecimento sobre informação do diagnóstico foi revivida na Atenção Básica.

Estando sua família cadastrada na Estratégia Saúde da Família da UBS Jardim d'Abril, recebia mensalmente, em visita domiciliária (VD), as agentes comunitárias de saúde (ACS) para o acompanhamento das condições de saúde de sua mãe, hipertensa e diabética e para verificação da situação vacinal de Luana, sua filha. Não havia sido abordada diretamente pela ACS sobre sua condição de soropositividade ao HIV e não abriu esta conversa com ela, por medo de exposição do diagnóstico no bairro onde reside. Contudo, posteriormente, diante dos questionamentos da 
ACS acerca da carteira de vacinação de Luana, Sofia acabou abrindo a informação sobre o diagnóstico, enfatizando seu temor em relação a garantia do sigilo.

Sofia lembra que em uma ocasião levou Luana à UBS para vacinação, contudo não ficou satisfeita com a conduta adotada nesta instituição. A enfermagem não indicou a administração da segunda dose da vacina contra o rotavírus, dado perda do intervalo recomendado pelo Programa Nacional de Imunização. Segundo Sofia, a aplicação da segunda dose foi indicada pela médica do SAE e este atraso ocorreu devido à espera do resultado do exame de carga viral de Luana. Esta informação foi dada por Sofia, sem registro por escrito quanto à indicação da vacinação, o que gerou exposição ao explicar seu caso à equipe da vacina. Esta situação suscitou medo de que a informação sobre seu diagnóstico fosse conhecida por outras pessoas que frequentavam a UBS ou até mesmo entre os trabalhadores, alguns inclusive moradores no bairro.

Este constrangimento foi gerado pela falta de comunicação entre os diferentes pontos da atenção - UBS e serviço de referência, pois o SAE não registrou por escrito a indicação da vacina mesmo com atraso e a UBS não contatou o SAE diante da incerteza, transferindo a responsabilidade da comunicação ao usuário.

Por não ter sido atendida quando buscou satisfação de uma necessidade específica - aplicação de vacina - e por ter que expor sua condição de soropositividade ao HIV, ficou insatisfeita com a UBS. Desta forma, foi desperdiçada uma oportunidade de restabelecer o vínculo entre usuária e serviço. Acompanha sua mãe eventualmente nas consultas, mas não vem utilizando o serviço para responder as suas necessidades de saúde. Ainda que distante, manteve vínculo com a médica da equipe de saúde da família, compartilhando com ela as experiências de superação e o seu retorno à rotina de estudo, trabalho, cuidado de sua mãe e sua filha, além do cuidado de si própria. 
Após o nascimento de Luana, Sofia manteve acompanhamento no SAE, tanto para si mesma, em consultas de rotina, quanto para sua filha, em consulta de puericultura. Apreende-se das narrativas que Sofia não se sentia insegura quanto a possível infecção de sua filha, acreditando na efetividade das medicações prescritas para evitar a transmissão vertical.

Sofia avalia que sua adesão ao tratamento com antirretrovirais durante a gestação era melhor que após o nascimento de Luana, embora venha se mantendo presente às consultas e compreenda a extrema importância dos medicamentos. Em uma ocasião chegou a suspender o tratamento entre o período de um exame e outro de carga viral, para avaliar se ainda precisaria dos antirretrovirais. Contudo, após poucos dias sem as medicações, iniciou quadro gripal, semelhante ao que julga ter sido os primeiros sintomas da infecção. Assim, convencida sobre a importância do tratamento contínuo com os medicamentos, voltou a tomá-los, ainda que esporadicamente irregular.

"então, aí eu parei de tomar uma vez só, como eu fiquei gripada forte duas vezes, duas semanas seguidas, a primeira vez a garganta inflamou, eu falei sabe, gripe duas vezes...minha garganta inflamou e aí eu já fiquei preocupada e comecei a tomar...(risos...). Aí eu voltei tomar normalmente e não deu tempo de fazer o teste...(risos...)"

"Ai, podia ser uma balinha, podia ser uma balinha doce de manhã e uma balinha doce à noite. Se tem que tomar, a gente até não ia esquecer. Mas os comprimidos são enormes e o outro é horrível. Um é ruim e o outro é enorme. Então, é, fica um pouquinho difícil. Então falaram, que não tem outra alternativa, né, então, não tem pra onde correr. Sem a medicação, eu não vou ficar bem, né? E ela [médica] ficou realmente com medo de tirar, porque ela queria 
tirar, né. Mas não teve como testar, porque a imunidade baixou muito"

Seu maior estímulo para a adesão ao tratamento após o nascimento de Luana continuava sendo sua filha, pois, ao ser questionada sobre planos futuros, disse que seu principal sonho é ver sua filha crescer e ver seus netos e por isso compreendia a importância do tratamento para o alcance deste sonho. Mencionou que inevitavelmente refletia sobre a morte, mas não em uma perspectiva entristecida, mas no sentido de planejamento, entendendo que assim teria uma vida mais tranquila. Por exemplo, apostando na possibilidade de melhores condições do novo trabalho, planejava a compra de um automóvel e a aquisição de seguro de vida para sua filha e para sua mãe.

No momento da entrevista, Sofia apresentava-se tranquila e confiante quanto ao futuro. Percebeu que várias situações de sua rotina retornaram ao normal e que muitos medos, que se apresentaram no momento da revelação do diagnóstico, foram minimizados diante do reconhecimento de que é possível viver com o HIV. Assim, relatou:

"poxa, se isso (seu novo trabalho) deu certo, as outras coisas vão voltando como você queria".

Ainda assim, seu maior incômodo em conviver com o HIV consistia no medo constante de ter seu diagnóstico revelado, prevendo que isto traria afastamento social e preconceito, e no fato de ter que ingerir as medicações diariamente. Mesmo diante do desafio de enfrentar a infecção e suas consequências, foi possível perceber uma postura ativa perante a vida, não de prostração devido às dificuldades de se viver com o HIV. 
No percurso detalhado acima em busca de cuidado foi possível constatar acesso aos serviços, que foi identificado pelos movimentos de Sofia nos diversos pontos da rede, desde Atenção Básica, Secundária e também Terciária. Além da identificação dos serviços, por sua trajetória foi possível conhecer como que estes serviços estão articulados (ou não) enquanto rede. Cabe agora apontar as fontes de apoio e sustentação que foram fundamentalmente importantes no direcionamento da trajetória de Sofia, já que a busca por cuidados em muitas ocasiões esteve influenciada pelo apoio de sua família, amiga e profissionais de saúde.

\subsection{FONTES DE APOIO E SUSTENTAÇÃO NA TRAJETÓRIA EM BUSCA DE CUIDADOS}

As trajetórias são realizadas segundo escolhas possíveis que as pessoas e suas famílias enfrentam no cotidiano, desvelando esforços para a resolução de seus problemas. No delineamento dos percursos empreendidos, redes sociais são acessadas, favorecendo experiências positivas e apoios de diversas formas (Bellato et al, 2011).

Em muitas ocasiões, a família tem se apresentado como elemento central do cuidado, pois é a família que, na maioria das vezes, busca, produz e gerencia o cuidado. Assim, é considerada como unidade produtora de cuidado, mas também como unidade que necessita de cuidados. Compreender a lógica das famílias possibilita a construção de um cuidar profissional ético e que valorize as experiências familiares, e que promova, proteja e preserve tal unidade produtora de cuidado (Bellato et al, 2011). 
Esse cuidado em saúde realizado por pessoas e famílias, favorece o acesso a múltiplas redes que possam dar sustentação e apoio no processo de buscar, produzir e gerenciar o cuidado. Assim, Bellato et al (2011, p.192) colocam que há duas formas de rede para cuidado em saúde: Rede de Sustentação e a Rede de Apoio para o cuidado.

Como Rede de Sustentação, definem:

aquela vinculada à pessoa adoecida de forma mais constante, configurando um núcleo de permanência na biografia e na produção do cuidado familiar, e que se mantém no tempo e espaço de forma mais perene. Essa rede comporta a noção de ser sustentáculo, manutenção e conservação ao longo da experiência de adoecimento e cuidado.

E como Rede de Apoio para o cuidado, conforme Bellato et al (2011, p. 192):

aquela conformada com sentido de ajuda ou assistência vinda do exterior, composta por pessoas que colaboram em momentos específicos e mais pontuais dessa experiência e envolvendo geralmente relações mais formais e de menor densidade afetiva

Assim, no percurso empreendido por Sofia, a Rede de Cuidados foi sendo tecida com a presença ora pontual, ora mais permanente, de pessoas que fortaleceram suas escolhas, auxiliando-a nas decisões, apoiando-a emocionalmente, encorajando-a em momentos necessários e de forma geral, influenciando a trajetória realizada em busca por cuidados.

Inicialmente, logo após ter seu diagnóstico revelado, Sofia temeu a reação da família, não sabendo se teria o acolhimento necessário. Como se observa no discurso: 
"e ai meu Deus, o que eu ia fazer com minha mãe, meu Deus, o que eu ia fazer com minha mãe, sabe, meus irmãos e aquilo foi desmoronando de tal forma que até acho que a Dra Carla falaria melhor, mas eu tive uma crise muito grande, eu não conseguia levantar do chão, eu não conseguia, eu queria gritar, eu queria...."

Estes questionamentos acerca da reação familiar fizeram com que Sofia procurasse como primeiro apoio uma colega de faculdade, que ao longo do tempo foi se mantendo como importante fonte de sustentação durante toda sua trajetória, como consta em sua fala:

"minha colega que foi minha irmã, e ela veio, ficou aqui em casa comigo, nós conversamos..."

"Minha colega, nossa minha amiga! Que trabalha, estuda comigo, nossa, ela me ajudou muito assim!!! Ela foi no SAE comigo também... Pra ver se meu exame tinha dado negativo. Ela que me segurou quando veio e eu quase morri".

A rede de sustentação composta por relações familiares foi tecida também no início, mas com cautela. Aos poucos, percebeu a necessidade de contar com o apoio familiar e, mesmo temendo as reações, acabou dividindo a informação sobre o diagnóstico, primeiro com seu irmão mais velho e, posteriormente com seu irmão mais novo, suas cunhadas e por último sua mãe. De prontidão, irmãos, cunhadas e mãe tornaram-se um importante núcleo produtor de cuidado. 
Representam-se na Figura 4 a composição familiar de Sofia, bem como a enumeração de suas principais fontes de sustentação, por meio da ilustração do genograma ${ }^{1}$.

Os números identificados no interior das figuras geométricas representam a idade de cada indivíduo. Quadrados e círculos, representam homem e mulher, respectivamente. O número localizado acima do quadrado ou círculo, conforme o sexo de cada um, refere-se ao ano de nascimento. A numeração no canto inferior direito do retângulo de cada indivíduo configura a ordem, em sentido crescente, das pessoas que ao longo do tempo ofereceram maior ou menor apoio.

Sofia enumera as principais fontes de sustentação:

"o primeiro é meu irmão de 36, a segunda nossa, é tão difícil....claro, minha filha, meu Deus! Minha filha!!!... Nossa, como eu posso falar da minha mãe... ela ficou muito abalada, ficou muito abatida, ela ficou muito pra baixo e ela acabou não me dando tanto apoio. Essa minha amiga, é a terceira. Essa é o quarto (a ex-cunhada), esse é o quinto (o antigo relacionamento), o meu irmão mais novo é o sexto e minha mãezinha, é a sétima".

${ }^{1}$ Para a composição do genograma abaixo utilizou-se o programa GenoPro versão 2011, um software para a construção de genealogias 


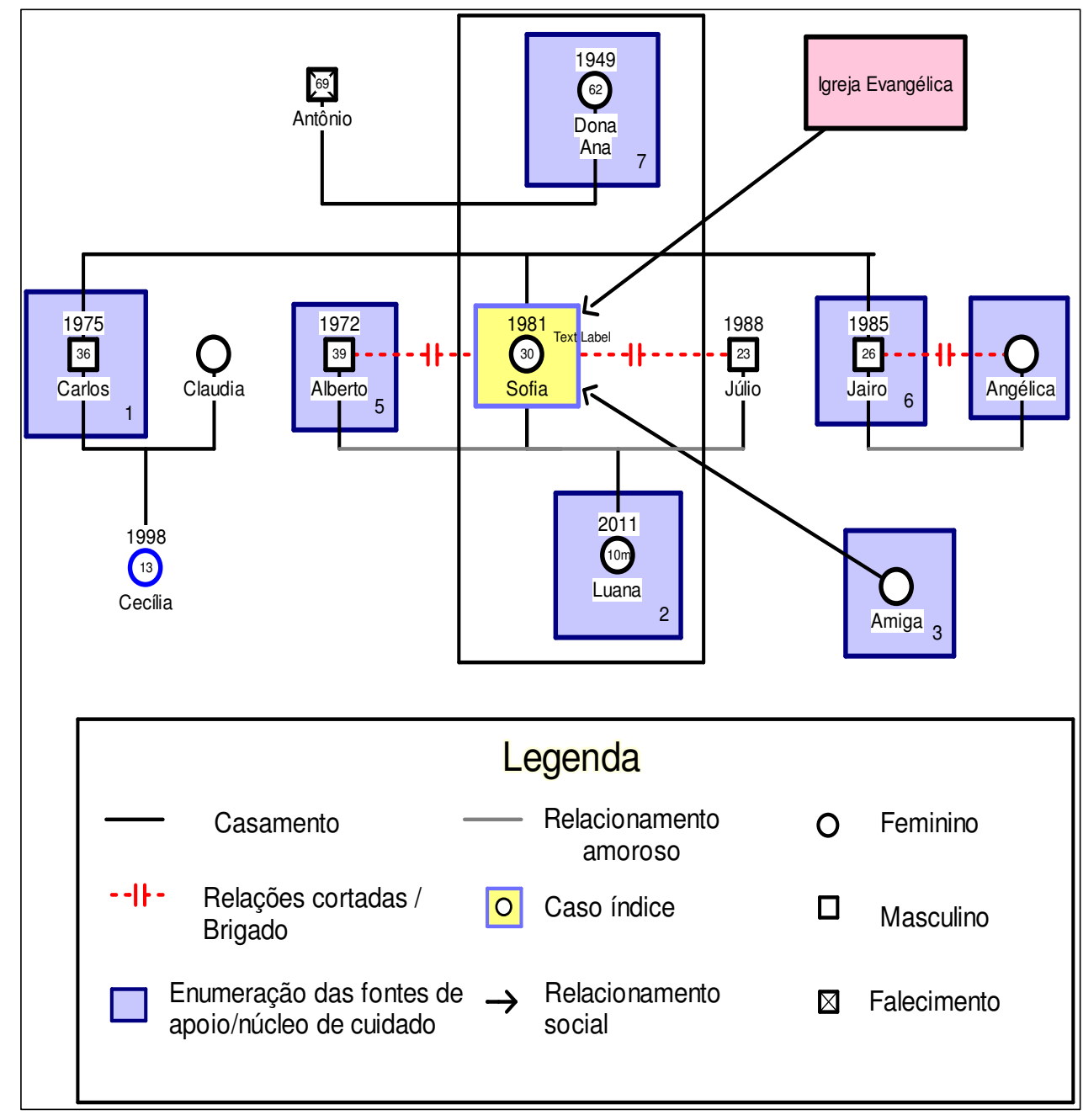

Figura 4: Composição familiar de Sofia e a enumeração de suas principais fontes de sustentação, por meio da ilustração do genograma

Embora tenha se questionado quanto ao apoio oferecido pelos seus relacionamentos amorosos, não seria possível os excluir do genograma, pois de uma forma ou de outra estiveram presentes em sua vida e influenciaram seu caminho e suas escolhas. Vale citar que Júlio, pai de sua filha, se afastou de Luana. Esta postura de Júlio gerou sofrimentos intensos em Sofia, pois segundo ela, não estava preparada para lidar com esta situação, 
principalmente diante da sua fragilidade de enfrentamento do diagnóstico e de toda adaptação de estar vivendo com o HIV. Em contrapartida, seu antigo relacionamento, ao longo do tempo se mostrou mais próximo e para Sofia, foi considerado como fonte de sustentação, pois a ouvia nos momentos que precisava.

O retângulo maior que envolve Sofia, sua filha Luana e sua mãe Dona Margarida, representa o núcleo de cuidado principal de hoje, pois são com estas pessoas que Sofia reside e vivencia as situações e desafios do dia a dia.

Sua mãe tem 62 anos, passou a morar junto após o nascimento da neta. É uma importante fonte de sustentação, mas vem diminuindo sua capacidade de oferecer apoio a Sofia, pois segundo ela, percebe que vem ocorrendo alterações nas suas condições de saúde e agravamento das doenças de base, hipertensão e diabetes.

Seus irmãos, dois homens, um de 36 anos e outro de 26 anos também são importantes fontes de sustentação durante sua trajetória. $O$ mais velho é uma pessoa-chave produtora de cuidado. A pessoa-chave é aquele que oferece apoio nos momentos difíceis, conferindo organicidade à rede de sustentação para o cuidado (Bellato et al, 2011), é alguém em que se muito confia, como foi possível observar nas narrativas de Sofia:

"Meu irmão, eu não sei se é espiritual, ou se é um psicólogo, ou se é tudo.."o (irmão) mais velho dizia: não, vamos não focar no problema, vamos focar na solução"

Sofia contou com a cunhada que, mesmo separada do irmão mais novo, ofereceu apoio durante o período inicial de diagnóstico, estabelecendo com ela diálogo e expressando suas angústias. 
"se não tivesse sido eles também...eu não sei se eu aguentaria, porque meu irmão veio, para te contar, foi um horror, eu tive uma cunhada que me deu total apoio, ah, e só realmente as pessoas de casa que sabem...". "nossa, ela, meu Deus, ela foi assim...muito boa...eles não estão mais juntos...ela foi muito legal"

Sofia ainda lembrou que uma expressão importante de apoio foi sua ajuda nos preparativos para a chegada da sobrinha, demonstrando com este gesto, aceitação e amorosidade:

"Nossa, participou mesmo! Depois eu te mostro o quarto, ela que fez tudo. Tudo sabe? Porque eu não estava a fim de comprar nada, ela que montou tudo pra mim. Veio aqui pintar, trouxe um monte de coisas, ixi, ela me deixou pra cima bastante. Aí já ajudou muito. E de conversar, né? Ai, eu tinha muita necessidade de falar. Com quem eu vou falar, então era com ela que eu desabafava bastante".

Nota-se que durante sua trajetória as pessoas inseridas na Rede de Sustentação foram especialmente importantes para o retorno de suas atividades e até mesmo para que a usuária procurasse auxílio profissional.

Nas narrativas fica evidente a conformação da crença religiosa, com a presença da igreja e do SAE como Fonte de Apoio. A Igreja está relacionada a um apoio espiritual de forma geral, aquele que oferece conforto, sem ser uma orientação ou apoio relacionados especificamente à infecção pelo HIV, inclusive porque Sofia não contou em sua comunidade evangélica sobre o diagnóstico. 
"quando você chega, parece que tem uma palavra de amizade, eles de certa forma falam da sua vida, não assim que Deus vai te castigar, então é um apoio mesmo, um conforto, porque Ele está sempre do teu lado. Não é que vai te castigar, se você errou, Ele está ali pra te apoiar, sabe, pra você não errar mais, então as palavras entram e te conforta".

No SAE, Sofia expressa uma relação de vínculo com o serviço, no sentido de ser um local onde não se preocupava em esconder o diagnóstico e onde as necessidades em relação ao acompanhamento da infecção eram respondidas. Sua narrativa reflete esse apoio, tanto do serviço de forma geral, quanto de alguns profissionais particularmente.

"sabe, foi um conjunto de tudo, porque de certa forma você desabafa sua vida com o médico, aí você fala assim: poxa, por que comigo? Aí ela te escuta, ela não precisava, ela só precisava dar o resultado do exame, aconteceu isso, isso, você faz isso e isso. Não, ela escutou toda a minha história, do meu relacionamento, ela viu toda a minha história de quem poderia ser, ela me escutou, sabe, ela foi uma psicóloga e uma médica".

Sofia não citou diretamente o fato de cursar ensino superior e o seu trabalho como integrantes de sua Rede de Apoio, mas foi possível observar, por meio das narrativas, o quanto estes foram importantes fontes de motivação para enfrentar o desafio de viver com o HIV. Posto que, no momento de revelação do diagnóstico, Sofia angustiou-se intensamente com a possibilidade de perder o desejado emprego. Mais ainda, após o 
nascimento de Luana, ao retomar a rotina de trabalho e estudos, teve a dimensão destes para sua satisfação pessoal.

Após apresentação e apontamento da importância das fontes de apoio e sustentação, inclusive na manutenção do acompanhamento e tratamento, no que se diz respeito à adesão, convém a seguir ilustrar conjuntamente os movimentos de Sofia nos serviços por meio do itinerário terapêutico, para em seguida, discutir os nós da integralidade neste percurso. 


\section{ITINERÁRIO TERAPÊUTICO: FRAGILIDADES E POTENCIALIDADES NO EXERCICIO DA INTEGRALIDADE NO PERCURSO EM BUSCA DE CUIDADOS}

Neste capítulo discutem-se os resultados apresentados no capítulo anterior. Para tanto, primeiramente ilustram-se os movimentos de Sofia ao longo da trajetória em busca de cuidados, com auxílio do itinerário terapêutico. Este percurso em busca de cuidados não foi linear e contínuo, como também não é o caminhar da vida.

Tomam-se no estudo os nós da integralidade, entendidos como pontos de apoio e sustentação, que favorecem o exercício da integralidade e ao mesmo tempo nós no sentido de se conformarem como pontos dificultadores para a efetivação da integralidade. Desta forma, discorre-se sobre as fragilidades e potencialidades no exercício da integralidade no percurso em busca de cuidados. Estas incluem, tanto ações realizadas pelos profissionais e serviços de saúde, quanto aquelas que compõem a rede familiar e social.

\subsection{ITINERÁRIO TERAPÊUTICO: FRAGILIDADES NO EXERCÍCIO DA INTEGRALIDADE NO PERCURSO EM BUSCA DE CUIDADOS}

Ao considerar a importância do IT (Itinerário Terapêutico) como uma tecnologia avaliativa em saúde, por meio desta ferramenta foi possível ilustrar os movimentos de Sofia em busca de cuidados na rede de serviços de saúde do Município de São Paulo. A fim de compreender as fragilidades e potencialidades da integralidade nesta trajetória, os desenhos que se 
seguem possuem o objetivo de ilustrar esquematicamente o percurso narrado acima. É importante lembrar que o IT permite retratar os sentidos das práticas dos profissionais para os usuários e de como, nas práticas concretas em saúde, é possível haver resolubilidade e integralidade da atenção (Bellato, Araújo e Castro, 2008).

Desta forma, para visualização do percurso, segue abaixo a ilustração do IT, composto pelo desenho em sequência temporal, seguido do desenho espacial. Estão compreendidas no IT, a identificação dos recursos assistenciais e as fontes de apoio e sustentação na busca por cuidado em saúde.

Na Figura 5, destaca-se o período antes e após a descoberta do diagnóstico, com diferenciação das cores no preenchimento dos quadriláteros, indicando divisão entre o momento antes e depois de saber do diagnóstico, pois, como citado anteriormente, até a primeira consulta de prénatal sua busca por cuidados era inespecífica e eventual, passando posteriormente a seguir uma lógica de cuidados direcionada à infecção pelo HIV. 


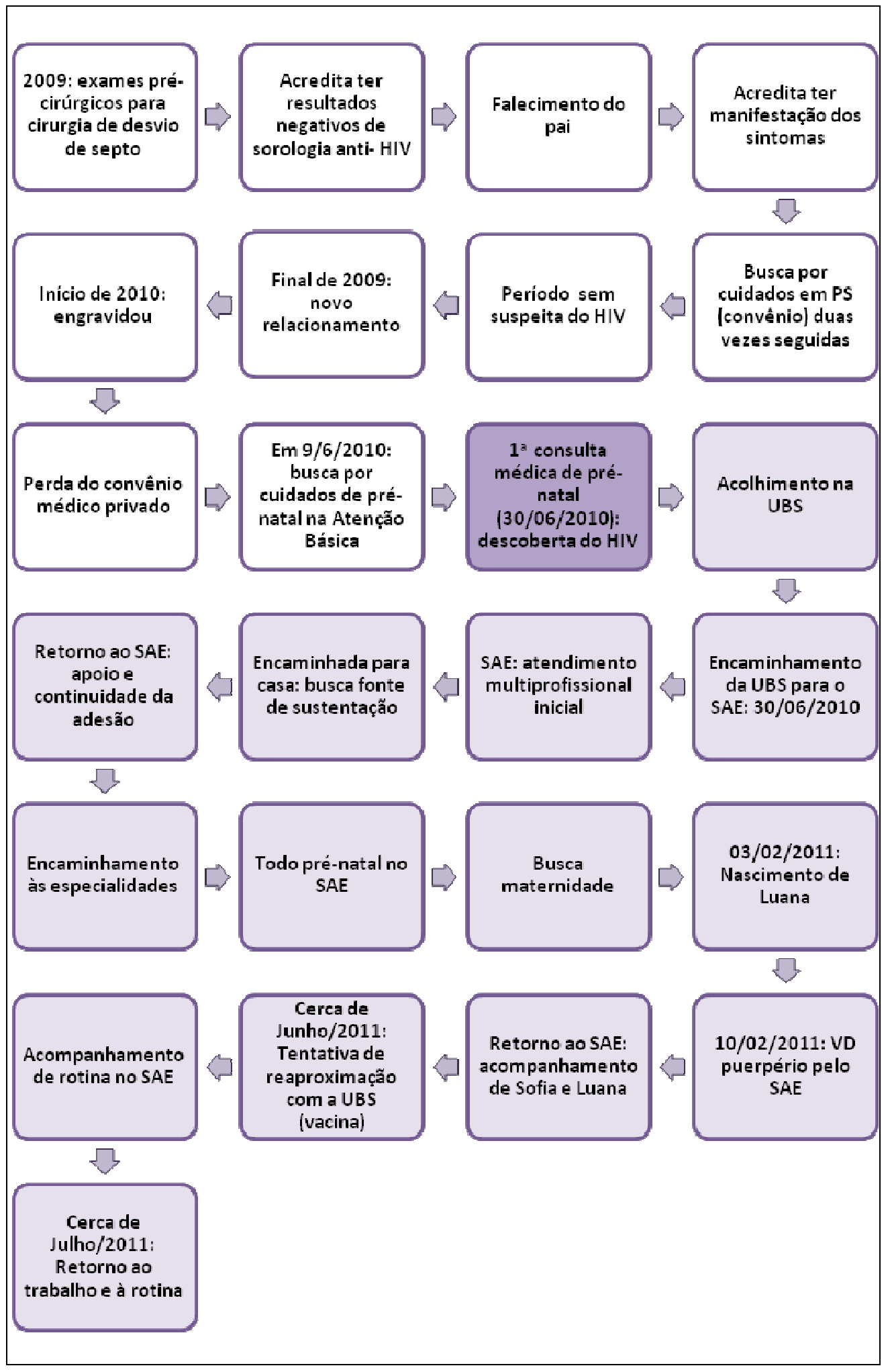

Figura 5: IT temporal do percurso de Sofia 
Após a apresentação do IT temporal, abaixo segue o desenho esquemático dos movimentos em busca de cuidados, sendo estes, tanto cuidados formais nos serviços de saúde, quanto cuidados em busca de conforto emocional e espiritual, na família, amiga e Igreja.

A Figura 6 a seguir ilustra os movimentos de Sofia em busca por cuidados em ordem cronológica e em sentido horário, sequência indicada pela numeração das setas. Conforme a legenda, as setas apontam: a busca por cuidados partindo de Sofia ou dos serviços; a referência formalmente escrita realizada pela UBS ao SAE; e os encaminhamentos que possivelmente foram realizados do SAE aos serviços de especialidades (dermatologia e oftalmologia) e à maternidade. Como segundo as narrativas, não foi realizada referência escrita aos serviços, estes possíveis encaminhamentos estão ilustrados por setas pontilhadas não numeradas, demonstrando, portanto, uma comunicação truncada entre estas instituições.

Observa-se que as Fontes de Sustentação e Apoio também não possuem numeração, pois a busca por estes suportes se deu de forma aleatória e constante em todo o percurso.

Nota-se também que, nas setas direcionadas ao SAE a numeração indica um intervalo, como se observa nos intervalos 8-23; 26-31 e 37-47. Como o SAE foi o principal serviço de acompanhamento, no total somam-se 33 movimentos de Sofia em direção ao SAE, desde a primeira busca logo após encaminhamento da UBS, até a última consulta de acompanhamento de rotina, antes da entrevista. Como seria incompatível inserir todos estes movimentos, optou-se por ilustrá-los em intervalos. O primeiro intervalo (823) retrata os acompanhamentos no SAE antes de ser "encaminhada" às especialidades de dermatologia e oftalmologia. O segundo intervalo (26-31) demonstra a busca por cuidados no SAE até o momento do nascimento de Luana, e o terceiro intervalo (37-47) indica a busca por cuidados após o nascimento de Luana até o último atendimento antes da entrevista. 
Resumidamente, as setas um e dois indicam a busca por cuidados no PS, após quadro alérgico e gripal, que Sofia acredita ter sido os primeiros sintomas de sua infecção. A seta três indica o primeiro contato com a UBS, ao realizar teste de confirmação da gravidez e ao ser inserida no fluxo de pré-natal da unidade. A seta quatro indica Sofia buscando a UBS para a realização dos exames laboratoriais do primeiro trimestre gestacional. A seta cinco indica a antecipação da consulta e comunicação desta antecipação à Sofia, e a seta seis indica a primeira consulta médica de pré-natal, em que o diagnóstico de HIV foi revelado. Em sequência, a seta sete indica a referência formalmente realizada pela UBS ao SAE. Em seguida, como já citado, encontra-se os intervalos de acompanhamento da Sofia no SAE, intercalados pelo acesso aos serviços de especialidades, dermatologia e oftalmologia. Posteriormente, as setas trinta e dois e trinta e três indicam o acesso consecutivo de Sofia à maternidade e logo após o nascimento de Luana, a seta trinta e quatro indica a VD de puerpério realizada pelo SAE. A seta trinta e cinco aponta o contato que Sofia realizou com a UBS, a fim de vacinar sua filha com a segunda dose da rotavírus e a seta trinta e seis indica a VD realizada pela ACS, cujo foco era sua mãe, dona Margarida e a caderneta de vacinação de sua filha Luana. E por último, o intervalo 37-47 indica os últimos acompanhamentos que ocorreram antes da entrevista. 


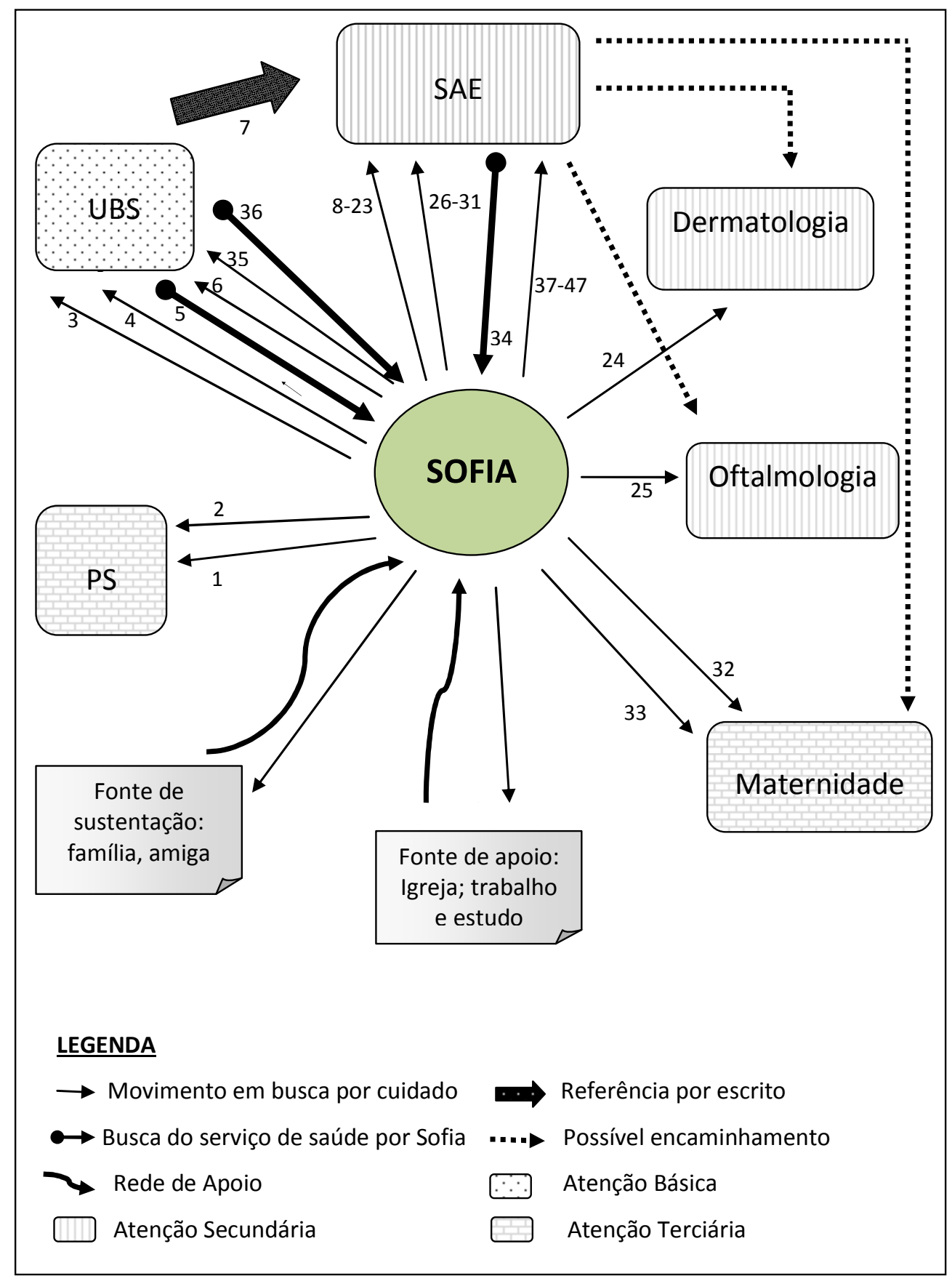

Figura 6: Desenho espacial da trajetória empreendida por Sofia 
É possível observar que a maior quantidade de movimentos, indicados por setas, como explica a legenda, tem em Sofia o ponto de partida, que demonstra ora se movimentando em busca de cuidados, ora retornando dos serviços de saúde. De forma que, está nela o elo integrador entre os diferentes serviços assistenciais de saúde, pois de forma geral, foi por seus movimentos que um esboço de rede foi sendo estabelecido.

Conforme Bellato, Araújo e Castro (2008), os usuários, em busca de cuidados, ao transitarem pelos diversos pontos da rede de serviços de saúde, constroem pontos e faces de intersecção e mediação entre eles, buscando resolução para seus problemas e construindo a integralidade à sua maneira.

São raros os momentos em que a busca por cuidados não parte de Sofia: o primeiro, indicado pela seta número cinco, quando a UBS antecipa a consulta de retorno no pré-natal ao identificar o resultado positivo para o HIV e liga para a usuária informando a antecipação da consulta. $O$ segundo momento, indicado pela seta número trinta e quatro, quando ocorre a VD de puerpério realizada pela equipe do SAE e o terceiro momento, quando a ACS realiza VD mensal com foco na caderneta de vacinação, indicada pela seta trinta e seis.

Esta centralidade da busca por cuidados no usuário, the confere posição potencialmente estratégica na avaliação dos serviços de saúde. Como avaliador da rede de atenção, pode exercer mais ativamente o lugar de sujeito de direitos, conforme salientam Pinheiro e Silva Junior (2011, p.39):

Quando realçamos a avaliação na perspectiva do direito, conferindo centralidade no usuário como mais um avaliador legítimo, as práticas avaliativas tornam-se amplificadoras desse direito, influenciando de modo crítico a oferta de cuidados, possibilitando maior qualidade e resolutividade ao conjunto da população. 
Um espaço formalizado no SUS para que de fato o usuário participe do processo de avaliação dos serviços está garantido por meio de representação nos Conselhos de Saúde, das Unidades de Saúde e das diferentes esferas de governo, nos municípios e Estado. Na cidade de São Paulo, a perspectiva avaliativa dos serviços, ações e planos de enfrentamento da epidemia daqueles que vivem ou estão implicados com HIV estão contidos nas Conferências Municipais de DST/aids realizadas no município (São Paulo, 2002, 2005, 2009).

Outra instância legítima de participação e avaliação dos usuários se dá por meio da Sociedade Civil Organizada, com as organizações não governamentais. Historicamente estas têm imprimido avanços e conquistas para a proteção de direitos individuais e coletivos no campo da prevenção, assistência e dos Direitos Humanos das pessoas vivendo com HIV/aids (Pereira, Nichiata, 2011).

Voltando a Sofia, sua trajetória nos diversos pontos da rede de serviços ilustram práticas que fragilizaram e potencializaram a integralidade neste percurso.

Quanto às fragilidades da integralidade, várias situações ocorreram que prejudicaram o exercício de tal princípio, incluindo ações realizadas em cada serviço acessado ou mesmo entre os serviços.

Na Atenção Básica, o exercício da integralidade da atenção esteve fragilizado desde o início da trajetória de Sofia na UBS, pois segundo traduz, em nenhum momento recebeu orientações sobre DST/AIDS dos profissionais de saúde. Para além de receber orientações, discute-se que as ações da UBS foram voltadas a problemas pontuais e biológicos. A maioria das anotações em seu prontuário retratava atendimentos com foco na doença instalada, como por exemplo, ainda criança, havia o registro de condutas referente às queixas como gastroenterite aguda, escabiose, rinite alérgica e bronquite asmatiforme. 
$\mathrm{Na}$ adolescência e fase adulta, ao acessar a UBS, é mais evidente como o foco voltava-se a problemas específicos. Havia, por exemplo, no prontuário, o registro de atendimentos ginecológicos, em que constava a solicitação de contraceptivos e citologia oncótica, bem como os resultados destas avaliações. Porém, Sofia não destacou, em seu relato, situações em que foram abordadas questões sobre sexualidade, saúde reprodutiva e mesmo vulnerabilidade a DST/HIV.

Recomenda o Ministério da Saúde (2006a) que a discussão sobre vulnerabilidade ao DST/AIDS deve estar presente em diversos contextos, tanto em atividades informativo-educativas realizadas na comunidade pela ACS ou outro profissional de saúde, quanto na unidade básica. As abordagens de tais temas devem estar inseridas desde o acolhimento do usuário à unidade, até ações de promoção à saúde, realizadas em grupo, como o planejamento familiar ou realizadas em atendimentos individuais, por meio das consultas. Há também orientações para que se realize a identificação dos indivíduos e famílias mais vulneráveis, para que em equipe, sejam planejadas intervenções de promoção à saúde.

O Ministério da Saúde enfatiza também a necessidade de inclusão da discussão destes temas nas VD mensais, inclusive com orientações sobre os insumos de prevenção. Outra recomendação é que as UBS organizem fluxo de acolhimento para quem deseja realizar o teste anti-HIV, incluindo aconselhamento individual durante consultas. Lembra ainda que esta abordagem deve ser norteada por um diálogo livre de preconceitos, com o objetivo geral de que toda pessoa atendida na UBS possa ter acesso às informações sobre DST/AIDS e se perceba vulnerável à epidemia (Brasil, 2006a)

Nos serviços de saúde ainda é distante esta prática. Em estudo sobre atividades de prevenção das DST/AIDS na Atenção Básica, Ferraz e Nemes (2009) discutem que há pouca abordagem sobre sexualidade e saúde reprodutiva nos serviços da Atenção Básica. Quando há, por exemplo, 
atendimentos de abordagem preventiva, como coletas de citologia e grupo de planejamento familiar, a discussão sobre o uso do preservativo e prevenção de DST/AIDS é genérica e normativa. As autoras apontam que as usuárias tem pouca oportunidade de falar sobre suas vivências e quando há abertura para falar de sua vivência, as experiências não se refletem na discussão de recomendações específicas, adequadas às necessidades singulares. O estudo ainda enfatiza que a abordagem das DST ocorre de forma fragmentada, pois as condutas se resumem à prescrição medicamentosa e ao diálogo restrito, não havendo discussões sobre modos de transmissão nem métodos de prevenção.

Em outro estudo, as mulheres pesquisadas que vivem com HIV indicaram não ter encontrado espaços suficientes para conversar sobre sua vida sexual. Este mesmo estudo também apontou que a maioria destas mulheres nunca havia sido atendida em aconselhamento, o que chamou bastante atenção, já que vivia em cidades com grande número de casos de aids e onde se concentravam muitos recursos de assistência especializada (Paiva et al, 2002). Confirmando o que se segue nos estudos acima, Sofia esteve em contato com serviços de saúde e parece não ter tido oportunidade de discutir sua sexualidade, bem como prevenção de DST/AIDS.

O Ministério da Saúde reconhece que de forma geral, as equipes de saúde ainda sentem dificuldades na abordagem sobre sexualidade, o que tem resultado em intervenções que não respondem às necessidades específicas das pessoas, tendo em vista os contextos de vulnerabilidade onde se encontram inseridas. Desta forma, para a realização de intervenções que interfiram na realidade destes usuários, recomenda 0 aperfeiçoamento da escuta e da abordagem dos profissionais de saúde, para que estes considerem as especificidades biológicas e sociais que cada usuário está vivenciando (Brasil, 2007).

Merece destaque a discussão da centralidade de práticas curativas e prescritivas na Atenção Básica em detrimento da incorporação de práticas 
baseadas nas necessidades ampliadas dos usuários. Ferraz e Nemes (2009) apontam que há persistência de um arranjo tecnológico centrado na assistência médica individual e na abordagem exclusiva da dimensão biológica do adoecimento, que impede a incorporação de atividades preventivas em geral. Para as autoras,

\begin{abstract}
No caso das DST/AIDS, esse arranjo, somado à já bastante estudada dificuldade dos profissionais de saúde em discutir claramente a vivência da sexualidade e, mais ainda, as questões de gênero nela implicadas, conflita com os referenciais éticosnormativos que têm fundamentado a proposição destas atividades pelo PN DST/AIDS.
\end{abstract}

Nichiata (2010), ao analisar os determinantes da vulnerabilidade programática das práticas das equipes de Saúde da Família para o enfrentamento do HIV/AIDS, também identificou que a temática HIV/aids muitas vezes é tratada de forma velada, por estar associada à discussões sobre sexualidade. A autora constatou que as atividades de prevenção das equipes de saúde da família, da região pesquisada, adotaram intervenções com base na generalidade das informações sobre HIV/AIDS e no senso comum, com ênfase na mudança de comportamento e caráter normativo, tomando o conceito de risco para a infecção ao HIV.

A autora apontou que há pouca definição tecnológica sobre atenção em HIV/AIDS no campo da ESF e que o foco do cuidado centra-se na assistência ao indivíduo, tendo como base o modelo biológico hegemônico e a concepção multicausal da enfermidade. Desta forma, indica em seu trabalho, que é fundamental a construção de novos saberes e novas práticas de atenção em HIV/AIDS, que considerem as necessidades dos indivíduos, família e coletividades e que incluam também, as percepções e construções sociais e culturais para o alcance da real finalidade do trabalho em saúde: a produção de cuidados (Nichiata, 2010). 
Ao tomar condutas baseadas somente nas queixas que os usuários apresentam, corre-se o risco de tornar biológico um problema que envolve determinantes sociais, desconsiderando assim a magnitude que a queixa de fato possui, reduzindo a importância da discussão, escuta e planejamento longitudinal da intervenção em saúde para uma ação prescritiva e pontual, que não modifica comportamentos. Geralmente essas condutas, segundo Egry, Oliveira (2008, p.37), estão associadas à implementação de programas verticais, que não atendem as necessidades dos diferentes grupos sociais de um determinado território e "estão em contradição com a concepção crítico-emancipatória de necessidades, pois se baseiam na perspectiva reducionista e biológica da saúde e da doença".

A abordagem centrada exclusivamente no modelo biomédico mostra-se insuficiente para atender a pessoa vivendo com HIV, pois não leva em consideração outras dimensões da vida e negligencia muitas questões amplas, como a vivência da sexualidade, os contextos sociais e econômicas do adoecimento. Portanto, este modelo produz uma assistência fragmentada e parcial e não considera que os problemas de saúde estão imersos em uma rede complexa de determinações (Takahashi, 2006).

$\mathrm{Na}$ direção da superação de práticas de saúde reducionistas, é necessário visão de mundo que transcenda os limites do ser biopsicossocial e tome o social como uma categoria e não como um fator causal do processo saúde-doença (Egry et al., 2010). É necessário o reconhecimento da concepção de homem como um ser social, que vive em relação com outros homens e seu meio, que o transforma e é transformado por ele. Desta forma, não se tem como foco o corpo biológico e sim, sujeitos sociais. Assim, ao partir para a prática, busca-se identificar o problema de saúde não somente do ponto de vista técnico-científico, mas compreendendo que este problema é vivenciado por um sujeito social, com necessidades que foram historicamente construídas (Matumoto, Mishima, Pinto, 2001). 
Portanto, reconhecer mais profundamente os determinantes e condicionantes que envolvem a queixa aguda de um usuário e contextualizar este usuário como um sujeito social, reconhecendo, portanto, além das demandas explícitas, ilustra uma postura fortemente associada à integralidade.

Assim, "buscar compreender o conjunto de necessidades de ações e serviços de saúde que um paciente apresenta, seria assim a marca maior desse sentido de integralidade" (Mattos, 2001, p.47). O mesmo autor coloca que a integralidade também está diretamente ligada à aplicação do conhecimento biomédico, por exemplo, se na abordagem essencialmente biomédica da consulta ginecológica a usuária fosse compreendida com base na integralidade, possivelmente a discussão de DST/AIDS teria sido abordada. Os encontros empreendidos com a usuária e os profissionais da UBS, ao menos nas consultas ginecológicas, são oportunidades potentes para fomentar um diálogo efetivo, tendo como ponto de partida a fala do sujeito, implicado no cuidado em saúde.

Merhy (1998) aponta que uma conduta essencialmente prescritiva e portanto, predominantemente biológica usualmente é um processo de produção de atos de saúde "procedimento centrada" e não "usuário centrada", em que se esgota na produção de um procedimento ou na finalização de um diagnóstico, sem que tenha atingido e satisfeito as necessidades e direitos dos usuários. Assim, para alcançar um ato que produza saúde, centrado nas necessidades dos usuários e norteado pela integralidade, faz-se necessária uma conformação adequada da relação entre três tipos de tecnologias, para produzir qualidade expressa em termos de resultados no sistema de saúde.

A tecnologia dura, segundo explica Merhy (1998), consiste principalmente na utilização de ferramentas e maquinarias necessárias para os procedimentos assistenciais, tais como instrumentos para a realização de exames laboratoriais, insumos de saúde, instrumentos cirúrgicos e de forma 
geral, as ferramentas de trabalho. Já a tecnologia leve-dura está relacionada ao saber que é necessário para realizar ações em saúde, tais como a clínica do médico, o saber e cuidado da enfermagem, etc. Há neste conhecimento científico uma parte dura, estruturada e outra leve, que está relacionado ao modo singular como os profissionais aplicam seu conhecimento para produzir cuidado. $\mathrm{O}$ autor aponta que o processo de trabalho, além de estar relacionado às tecnologias dura e leve-dura, também envolve subjetividades entre os sujeitos envolvidos, tanto entre o profissional de saúde e usuário quanto entre os profissionais.

Estas subjetividades emanam como substância viva no interior das relações de trabalho e são denominadas como tecnologia de relações, que se traduzem na produção de vínculo, acolhimento, autonomia, cumplicidade e responsabilização em torno do problema que vai ser enfrentado (Merhy, 1998; Meneses, 1998).

$\mathrm{Na}$ trajetória de Sofia, foi possível observar fragilidade nas tecnologias relacionais, impregnadas pela concepção biológica de compreender os problemas de saúde e o usuário. Esteve presente não somente na prática médica, marcada pelo ato prescritivo. A visão predominantemente biológica também esteve presente na atuação das ACS durante as visitas domiciliares. Segundo se avalia, nos encontros entre ela e os profissionais, a ênfase era dada invariavelmente em responder ao meio/instrumento que auxilia o cuidado em saúde e não em responder à necessidade do sujeito do cuidado.

Discute-se a importância da incorporação de práticas que, pautadas na integralidade, compreenda, a partir da vivência do sujeito, suas necessidades em relação ao cuidado da criança, para além da vacinação. $E$ mais, discute-se a necessidade de práticas que vão além da ênfase biológica.

Sofia, após o nascimento de sua filha Luana, tentou nova aproximação com a UBS, lembrando que o distanciamento ocorreu devido 
ao medo de exposição do diagnóstico perante a comunidade que frequentava a UBS.

A nova tentativa de vínculo deu-se novamente por meio do cuidado da filha, quando buscou acesso à segunda dose da vacina contra rotavírus. Conforme relatado anteriormente, sentiu dificuldade na abordagem realizada na sala de vacina, sendo questionada a conduta a ser tomada, que era diferente do que existe protocolado no calendário de vacinação. Esta situação mostrou dificuldade na escuta de uma necessidade posta por Sofia. A não acolhida e resposta à demanda trazida, segundo apreendeu-se da narrativa, trouxe o afastamento da usuária a este serviço de saúde.

Sendo ela porta-voz das informações sobre sua saúde, sobre as condutas a serem tomadas em relação ao acompanhamento da infecção, dela e da filha, sentiu-se exposta ao ter que explicar sua condição de soropositividade ao HIV a um trabalhador da enfermagem, responsável pela sala de vacina. Ao mesmo tempo, segundo Sofia, sua fala não foi considerada autorizada na sala de vacina, avaliando que seria uma fala oficial a prescrição por escrito de um profissional de saúde do serviço de referência em DST/aids.

Nota-se nesta situação fragilidade na efetivação da integralidade, tanto do ponto de vista da falta de articulação e comunicação entre estes dois serviços, SAE e UBS, quanto do não desenvolvimento de vínculo que poderia ter se reestabelecido com a UBS.

No SAE, houve fragilidade no exercício da integralidade quando se identificou inexistência de contrarreferência à UBS, bem como a falta de referência formal a outros serviços que Sofia foi encaminhada.

Ações com base na integralidade incluem a articulação entre os serviços, pois os diversos pontos da rede são justamente para comporem um acompanhamento contínuo, que atenda as necessidades do indivíduo. A ausência de comunicação dos vários pontos da rede de atenção sugere que 
outros tipos de comunicações, mais complexas, não estão ocorrendo entre estas instituições. Supõe-se que, desta forma, ocorre fragmentação e descontinuidade no cuidado.

A UBS necessita das informações do SAE para que em eventual consulta ou atendimento, tais informações possam ser úteis para direcionamentos mais adequados ao usuário. Desconsiderar a importância da contrarreferência sugere limitação da UBS ao contatar que ela se encontra apenas como porta de entrada, sem ser ela responsável pelo cuidado longitudinal dos indivíduos e suas famílias, em seu território de responsabilidade.

Além do SAE, com base nos discursos da usuária, os serviços de atenção especializada, como o de dermatologia e de oftalmologia também não remeteram contrarreferência ao SAE. Sofia percebeu descontinuidade e fragmentação da assistência quando questionou se os profissionais destes serviços conheciam sobre sua condição de soropositividade ao HIV, pois não os comunicou e também não sabia se o SAE Ihes havia informado, posto que não levou a estes serviços algum formulário que sugerisse informação de seu caso.

O sistema de referência e contrarreferência, prática antiga utilizada no Sistema Único de Saúde devido à regionalização e descentralização, deveria ser um meio de comunicação bastante efetivo entre as instituições de saúde, pois favorece a articulação entre elas e insere as unidades de saúde da família na rede de serviços, garantindo a este nível de atenção o acesso aos serviços de apoio diagnóstico, de especialidades, ambulatoriais, de urgências/emergência e de internação hospitalar (Brasil, 1997). Segundo o Plano Diretor de Regionalização (Brasil, 2002), o sistema de referência e contrarreferência possui o objetivo de garantir a integralidade da assistência e o acesso contínuo e articulado da população aos serviços e ações de saúde. 
Porém, nas práticas de saúde, estudos apontam que este sistema não vem sendo utilizado pelos profissionais de saúde. No Rio de Janeiro, um estudo sobre o sistema de referência e contrarreferência, em apoio à Estratégia Saúde da Família nos municípios de Duque de Caxias e Rio de Janeiro, constatou que havia deficiências nas condições operacionais básicas ao bom funcionamento deste sistema entre os serviços de saúde da família e os demais níveis de complexidade. As deficiências encontradas estavam relacionadas ao planejamento e regulação, gestão clínica, acesso aos serviços, recursos humanos, sistemas de informação e comunicação e apoio logístico, o que resultou em fragilidade no funcionamento da referência e contrarreferência, prejudicando assim, a integralidade e continuidade dos cuidados (Serra, Rodrigues, 2010).

Na região sul do Brasil, um estudo verificou como era estabelecido o sistema de referência em um hospital universitário, referência regional a usuários com HIV/AIDS. Constatou-se que a maioria dos sujeitos pesquisados não recebeu nenhum tipo de referenciamento ao nível hospitalar e também, após atendimento neste nível de atenção, não recebeu encaminhamento a outra unidade e nem contrarreferência a outros serviços. Contradizendo, portanto, a lógica de manter o usuário assistido e acompanhado em todos os níveis de forma contínua e integral (Lemões, Costa, Mandoza-Sassi, 2010)

Corroborando o que se encontrou na trajetória de Sofia, um estudo realizado na cidade de Fortaleza-CE, verificou fragilidades no sistema de referência e contrarreferência entre os serviços de Atenção Básica e serviço especializado em HIV/AIDS, dificultando assim o processo de articulação entre os serviços e o atendimento integral aos indivíduos HIV-positivos. As autoras destacaram que os profissionais da ESF desconheciam as formas de acesso e a rotina do SAE, bem como os profissionais do SAE desconheciam a rotina e a dinâmica de atendimento em HIV/AIDS da ESF. As autoras apontaram que se houvesse comunicação entre esses dois níveis de assistência, alguns procedimentos poderiam ser compartilhados 
entre os serviços. Para tanto, o estudo apontou a importância do interesse e atuação gerencial no desenvolvimento de transformações que favoreçam tal comunicação (Silva et al 2005).

Outro estudo, na perspectiva de avaliação dos serviços de saúde, realizado na região sul do município de São Paulo, analisou o sistema de referência e contrarreferência entre as UBS e o serviço de assistência especializada às pessoas vivendo com HIV. E constatou que a comunicação entre tais serviços era praticamente inexistente. Todos os sujeitos entrevistados, gerentes das UBS, destacaram a importância da contrarreferência, apesar de reconhecerem que esta comunicação raramente ocorria e que muitas vezes era realizada pelo próprio paciente. Além disso, o estudo constatou que os instrumentos de comunicação existentes não propiciaram a integralidade das ações (Franco, 2011).

Os estudos acima retratam a perspectiva das instituições no que diz respeito à utilização do sistema de referência e contrarreferência. Ao compará-los com a trajetória de Sofia, avalia-se que tais achados se complementam, já que ambas as perspectivas apontam fragilidade deste sistema na atenção em HIV/AIDS, comprometendo assim, a integralidade das ações, no que se refere à continuidade e articulação da assistência nos diversos pontos da rede.

Esta descontinuidade da assistência nos diversos pontos da rede foi possível de ser observada no IT. O desenho esquemático da trajetória espacial de Sofia constatou que não houve setas demonstrando a articulação entre os serviços. Houve apenas um direcionamento, indicando a referência que foi formalmente realizada da UBS para o SAE. As demais tentativas de articulação, indicadas por setas pontilhadas (partindo do SAE para os serviços de dermatologia, oftalmologia e para a maternidade), não foram realizadas formalmente por meio do sistema de referência e contrarreferência, segundo as narrativas. 
Assim, ao analisar a trajetória como um todo e os movimentos de Sofia nos diversos pontos da rede de saúde, foi possível observar que cada serviço, individualmente, apresentou dificuldades no exercício da integralidade, que podem estar relacionadas à organização do próprio serviço, à organização dos serviços de saúde no município e à organização do programa de atenção em HIV/AIDS no município.

Evidenciou-se que cada serviço buscou resolubilidade no que era de sua competência, porém as diversas instituições acessadas atuaram de forma isolada, fragmentada, descontínua, não caracterizando de fato, uma rede de atenção, pois as setas em busca de cuidado foram majoritariamente direcionadas aos serviços, com raras setas que articularam os serviços.

Diante desta fragmentação e descontinuidade da assistência observada na trajetória de Sofia, este estudo apontou a necessária implementação das Redes de Atenção em Saúde, bem como organização de Linhas de Cuidado na Atenção em HIV/AIDS.

De acordo com o que se aponta neste trabalho, Ferreira (2011), ao estudar o itinerário terapêutico de pessoas com diagnóstico de HIV/AIDS no município de Juiz de Fora e ao analisar os significados atribuídos por estas pessoas sobre o processo de adoecimento e do seguimento terapêutico que recebem nos serviços de assistência neste município, também indica a necessidade de se realizar costura na rede de atenção, tendo em vista que isso melhoraria o processo de trabalho dos profissionais de saúde, bem como poderia se refletir na construção de um plano terapêutico satisfatório para todos os envolvidos neste processo, tanto profissionais, quanto pessoas que convivem com HIV.

Mendes (2010) coloca que sistemas de saúde fragmentados tem sido um desastre em termos econômicos e em níveis de saúde e, portanto, o autor defende a importância da organização das ações e serviços de saúde em Redes de Atenção em Saúde (RAS). As RAS são organizações poliárquicas, vinculadas entre si por um único objetivo, que exercem ação 
cooperativa e ao mesmo tempo interdependente. Ou seja, não se configuram em hierarquia, pois todos os pontos de atenção em saúde são igualmente importantes e se relacionam horizontalmente. Este tipo de organização evoca uma atenção integral, uma continuidade entre os diferentes níveis de complexidade e funcionam sob à coordenação da Atenção Primária em Saúde, que organiza suas ações com base nas necessidades em saúde de uma população.

Segundo o Ministério da Saúde (2010b),

\footnotetext{
Rede de Atenção à Saúde é definida como arranjos organizativos de ações e serviços de saúde, de diferentes densidades tecnológicas, que integradas por meio de sistemas de apoio técnico, logístico e de gestão, buscam garantir a integralidade do cuidado.
}

Já a Linha de Cuidado é uma proposta de reorganização dos processos de trabalho mais específica, com base na organização de fluxos assistenciais capazes de garantir acesso às tecnologias necessárias. Estes fluxos têm o usuário como elemento central e estruturante de todo processo de produção da saúde e opera com base na integralidade e nas necessidades de saúde dos usuários (Franco, Magalhães Júnior, 2004).

A organização dos serviços a partir da Linha de Cuidado configura a UBS como gestora do projeto terapêutico, responsável pela continuidade do cuidado ao longo do tempo. Os autores enfatizam que para esta reorganização é fundamental o envolvimento dos gestores de todos os níveis assistenciais, a fim de: facilitar o percurso do usuário em busca de cuidados nos diversos pontos da rede; disponibilizar recursos para a implementação das Linhas de Cuidado; e garantir a referência e contrarreferência aos diversos níveis de complexidade (Franco, Magalhães Júnior, 2004). 
Malta e Merhy (2010) ressaltam que a organização do serviço com base em Linhas de Cuidado deve promover ao usuário um caminhar na rede de serviços de forma segura e sem obstáculos. Apontam ainda que a linha de produção de cuidado não deve se esgotar no Projeto Terapêutico, mas que deve continuar no acompanhamento deste usuário ao longo do tempo, a fim de garantir a integralidade do cuidado em todos os serviços acessados. Para tanto, os autores salientam a necessária responsabilização tanto da equipe, quanto dos gestores públicos, para que não ocorram a interrupção e segmentação do cuidado.

As Linhas de Cuidado ao propiciarem a organização de fluxos com base na singularidade e necessidades dos usuários, favorecem a qualificação da atenção em saúde (Silva, 2011).

As propostas de implementação das Linhas de Cuidado estão voltadas predominantemente à organização de fluxos de doenças crônicas não transmissíveis, como é o caso das Linhas de Cuidado em Hipertensão Arterial Sistêmica (HAS) e Diabetes Mellitus (DM), desenvolvidas pelo Projeto de Investimento para a Qualificação do Sistema Único de Saúde (QualiSUS-Rede), que visa apoiar a organização de redes regionalizadas de atenção à saúde no Brasil (Brasil, 2009b).

Outra iniciativa em andamento é o Plano Municipal de Saúde de Diadema-SP, que desenvolveu Linhas de Cuidado também em HAS e DM, visando expandir a capacidade de atuação da ESF em doenças crônicas não transmissíveis e qualificar a rede de atenção à saúde por meio da gestão integral de linhas de cuidado (Organização Pan-Americana da Saúde, 2010). Além das Linhas de Cuidado direcionadas a HAS e DM, a Secretaria de Saúde do Estado de São Paulo incorporou as Linhas de Cuidado na Atenção à gestante e à puérpera (São Paulo, 2010e).

Apesar de as Linhas de Cuidado estarem normalmente mais aplicadas às doenças crônicas não transmissíveis, Silva (2011) aponta a importância das Linhas de Cuidado em HIV/AIDS, tendo em vista a 
possibilidade de favorecer uma organização mais específica dos serviços, voltada a planejar e monitorar a atenção individual de pessoas vivendo com doenças graves, como é o caso do HIV/AIDS.

Malta e Merhy (2010) apontam que a organização de Linhas de Cuidado abrange outros problemas de saúde, não se restringindo às doenças crônicas não transmissíveis, pois segundo os autores, o foco desta organização não é a especificidade da doença, mas sim o modo de cuidar que não vincula, que não opera com as tecnologias leves produtoras de singularizações no cuidado e que não tomam como planejamento das suas ações as necessidades do usuário. Portanto, colocam que a discussão e implementação das Linhas de Cuidado abrangem todos os contextos em que o cuidado precisa ser repensado.

Apesar de existirem várias iniciativas de implementação das Linhas de Cuidado, em HIV/AIDS esta discussão ainda é insipiente, de forma que são raros tais projetos de implementação em HIV/AIDS. O Grupo Hospitalar Conceição (GHC)/Porto Alegre-RS, lançou em 2006 um projeto sobre Linha de Cuidado em DST/AIDS, a fim de organizar os processos de trabalho com base no atendimento integral. O projeto envolve os setores de Emergência, Enfermaria, Hospital-Dia, Ambulatório, Unidades de Pesquisa Clínica, Unidades de Saúde Comunitária, Centros de Atenção Psicossocial e Odontologia. Além disso, inclui também o Programa de Transmissão Vertical (GHC, 2006). Porém, não foi possível avaliar se este projeto assume a Atenção Básica como gestora do cuidado, como colocam Franco e Magalhães Júnior (2004).

Franco (2011), ao analisar o sistema de referência e contrarreferência entre UBS que operam em ESF e o SAE da região sul do município de São Paulo, constatou a fundamental importância das Linhas de Cuidado para o enfrentamento da epidemia e para atenção em HIV/AIDS. E ainda propôs um fluxograma para operacionalização do atendimento em HIV/AIDS nas UBS que operam segundo a ESF. 
Portanto, o presente estudo complementa o que encontrou Franco (2011), visto que é necessário discutir a implementação das Linhas de Cuidado com os gestores de saúde responsáveis pelo Programa Municipal de DST/AIDS, a fim de contribuir para a construção de um Projeto Terapêutico na atenção em HIV/AIDS, que busque organização dos fluxos com base nas necessidades das pessoas vivendo com HIV e que contemple integralidade nas práticas de saúde.

Finalizando os fatores que fragilizaram a integralidade na trajetória de Sofia, discutem-se abaixo as práticas que dificultaram o exercício da integralidade na maternidade. A iniciar pela utilização inadequada do cartão de acompanhamento de pré-natal, em que por não leitura do mesmo, Sofia sofreu incômodos pela expectativa de exposição da revelação do diagnóstico e mais ainda pela conduta médica ter sido alterada subitamente ao observarem a soropositividade ao HIV, após apontamento da usuária.

O registro de informações em meios de comunicação formalmente instituídos não foi suficiente para a garantia da continuidade da assistência. Portanto, conclui-se que além da necessária organização dos serviços para melhoria da comunicação e articulação, também são fundamentais iniciativas individuais dos profissionais de saúde. Posturas estas que inclusive poderiam ser exigidas pela gestão dos serviços.

Outras situações na maternidade denotam não integralidade da atenção, traduzido no atraso, segundo o relato de Sofia, da administração do antirretroviral para o recém-nascido $(\mathrm{RN})$, bem como no atraso da oferta do leite artificial para o $\mathrm{RN}$.

Sofia também foi bastante enfática quanto ao vínculo estabelecido entre ela e os diferentes períodos diurno e noturno, pois segundo seu relato os atrasos ocorreram justamente no plantão noturno. Mais ainda, Sofia reclamou das práticas não humanizadas ocorridas neste plantão, práticas estas que não se conformaram com as condutas propostas pelo Ministério da Saúde (2003). A assistência adequada à mulher no momento do parto, 
além de ser um direito fundamental de toda mulher, é um passo importante para garantir que ela exerça a maternidade com segurança e bem estar. Para tanto, é necessário que a equipe promova a criação de vínculo com a gestante ou puérpera, transmitindo-Ihe confiança e tranquilidade, em uma postura de acolhimento (Brasil, 2003).

Percebe-se um distanciamento entre a prática encontrada na maternidade, segundo o relato de Sofia, e o que é preconizado pelo Ministério da Saúde (2003). O Ministério da Saúde, por meio do Projeto Nascer instituiu diversas condutas a fim de capacitar as equipes multiprofissionais das maternidades, com vistas à reorganização dos processos de trabalho para melhoria da qualidade do atendimento à gestante, puérpera e $\mathrm{RN}$, visando contudo, a redução da transmissão vertical do HIV e controle da sífilis congênita.

Esse distanciamento entre o que se propõem e o que ocorre na prática é refletido em alguns exemplos na trajetória de Sofia, tais como a não leitura do cartão de acompanhamento de pré-natal, os atrasos na oferta do leite artificial, a falta de humanização em algumas práticas de enfermagem e os problemas de comunicação entre os profissionais. Sofia relata que a falta de comunicação entre os profissionais foi percebida quando a dosagem aumentada de leite prescrita em um plantão não foi seguida em outro turno e também ao notar que alguns profissionais da enfermagem demonstraram não saber do diagnóstico. Segundo pondera, todos os profissionais envolvidos em seu cuidado deveriam saber dessa informação de forma sigilosa e sem que ela precisasse mencionar. Este é um alerta para a enfermagem, pois é ela profissional responsável pela gestão deste cuidado.

Nota-se que, por ser uma maternidade de referência para gestante vivendo com HIV, estas questões não podem ser vistas como banais. Tais exemplos sugerem a falta de comunicação cuidadosa, a inexistência de fluxos estruturados para o atendimento de mulheres vivendo com $\mathrm{HIV}$, o que consequentemente gera práticas fragmentadas e que não atendem 
integralmente a expectativa das usuárias. Mais do que uma atitude profissional individual, discute-se como institucionalmente deve-se implementar práticas de cuidado que levem em consideração as necessidades de mulheres que vivem com HIV.

Situação semelhante encontrou-se em uma maternidade em Teresina-PI, em que a organização do serviço, associado ao despreparo de alguns profissionais dificultou a assistência integral à mulher, gestante soropositiva. O estudo constatou que o processo organizacional do cuidado direcionado à mãe e filho "mostrou-se mais limitado e atrelado à vontade pessoal de uma parcela pequena de profissionais do que em mudanças efetivas verificadas no âmbito institucional” (Araújo e Nogueira, 2007, p.399)

No caso das parturientes e puérperas vivendo com HIV, o acolhimento pelos profissionais de saúde é particularmente fundamental, já que estas mulheres estão vivenciando processo doloroso de dúvidas e incertezas, diante da contraindicação do aleitamento materno e do risco de contaminação do concepto. Além disso, também estão sofrendo com o medo do preconceito e com as ansiedades relacionadas ao futuro seu e do filho. Portanto, é essencial oferecer suporte emocional e social, por meio de um cuidado humanizado, pois a gestação, o parto e o pós-parto são períodos singulares na vida desta mulher. É também atribuição dos profissionais de saúde minimizar as ansiedades mediante esclarecimentos específicos, visando à amenização dos dilemas e conflitos de ser mãe na vigência do HIV/AIDS (Galvão, Cunha, Machado, 2010)

Assim, foi possível concluir com as narrativas de Sofia, que os acontecimentos na maternidade marcaram de forma bastante negativa sua trajetória, o que indica a necessidade de se modificar os processos de trabalho e a organização dos fluxos de assistência, visando, contudo, um cuidado com base na integralidade, humanização e acolhimento.

Por último, não seria possível concluir a discussão sobre os nós da integralidade sem colocar considerações a respeito da invisibilidade do 
trabalho da enfermagem durante a trajetória em busca por cuidados. É importante resgatar que não se trata da ausência de contato com a enfermagem, pois Sofia reconhece a atuação da enfermagem no primeiro atendimento de pré-natal, na VD de puerpério e em procedimentos técnicos como coleta de sangue para exames laboratoriais, tanto na UBS, quanto no SAE, bem como cita a insegurança ao perceber que alguns profissionais de enfermagem na maternidade não sabiam do diagnóstico ao prestarem seus cuidados. O que se pretende discutir é justamente o fato de que o cuidado da enfermagem se evidenciou na trajetória de Sofia pelos procedimentos técnicos.

Ao considerar que o enfermeiro é responsável pelo planejamento, organização, coordenação, execução e avaliação dos serviços da assistência de enfermagem e tendo em vista que este profissional desenvolve ações nos três níveis de complexidade do SUS e portanto, deve estar engajado na luta pelos valores preconizados neste complexo sistema de saúde, supõe-se que ele também esteja envolvido na concretização do princípio da integralidade. É pelo cuidado que os enfermeiros conseguem aproximação, diálogo e formação de vínculo com os usuários, particularmente em momentos de fragilidade e dor (Antunes e Guedes, 2010).

Assim, tem-se a integralidade como importante princípio norteador da prática do enfermeiro e da enfermagem enquanto categoria profissional, pois não se busca cuidar apenas de partes do sujeito, mas sim de indivíduos portadores de necessidades inseridas em um processo histórico e político (Almeida e Rocha, 1997). 
Como colocam Fracolli e Bertolozzi (2008, p.28),

\begin{abstract}
Abordar a enfermagem como trabalho significa compreender que as práticas de saúde são práticas sociais e, portanto, devem ser tomadas para além de sua dimensão profissional e técnica, ou seja, para além de uma aplicação imediata e direta dos conhecimentos técnico-científicos. É pressupor que esta prática é determinada pela finalidade social do trabalho em saúde e, portanto, não é uma prática estática, mas dinâmica, pois requer a revisão periódica de seus elementos constituintes frente às transformações da sociedade e dos modelos de atenção à saúde.
\end{abstract}

Assim, diante de um conceito ampliado do trabalho da enfermeira e considerando que a integralidade, portanto, deve ser o princípio norteador de sua prática, esperar-se ia que suas ações estivessem mais evidenciadas na trajetória de Sofia, não destacadas apenas pelo seu saber e fazer técnico, mas que estivesse refletida nesta trajetória a realização de práticas que fortalecessem a integralidade.

Vários trabalhos apontam a importância da enfermeira no enfrentamento da epidemia. Considerando a "necessidade real e inegável de qualificação da força de trabalho em enfermagem para o enfrentamento da Aids", um estudo verificou que tal qualificação não deve estar pautada apenas em qualidades técnicas, pois ao considerar que em se tratando de HIV/AIDS, a enfermagem lida com relações humanas, muitas vezes conflituosas e nem sempre explícitas, é fundamental que se trabalhe as questões socioculturais, psicoemocionais e morais destes trabalhadores de enfermagem (Gryschek et al 2000)

Outro estudo apontou ser fundamental a aproximação do enfermeiro com a rede de apoio das pessoas que vivem com HIV/AIDS, a fim de incluir no planejamento da assistência as demandas provenientes deste contexto (Langendorf et al, 2011).

Leite et al (2007) consideram que, diante das dificuldades que as PVHA enfrentam no dia a dia, faz-se necessário um cuidado que considere 
além das carências biológicas. Porém, os enfermeiros ainda mantêm uma assistência tecnicista e normativa. As autoras indicam ainda que cabe à enfermeira conhecer a realidade de modo mais efetivo, bem como participar mais ativamente no desenho de políticas de enfrentamento ao HIV.

Carvalho (2010) ressaltou a importância da atuação da enfermeira ao sistematizar, desenvolver e avaliar o processo de cuidar. Esta mesma autora constatou que as consultas de enfermagem sistematizadas possibilitaram fortalecimento do autocuidado ao usuário vivendo com HIV. Ainda comprovou que após as consultas sistematizadas de enfermagem, houve melhora nos parâmetros relacionados à qualidade de vida, no que tange às preocupações destas pessoas quanto à vida sexual, quanto ao medo da revelação do diagnóstico e quanto às preocupações relacionadas às medicações. Além disso, apontou que após a intervenção de enfermagem, houve menores índices de depressão, ansiedade e melhora da adesão à terapia antirretroviral.

Conforme o que os estudos apontam, fica evidente que o trabalho da enfermagem favorece práticas de saúde em prol da integralidade no enfrentamento da epidemia da HIV/AIDS, no entanto, é invisível na trajetória de Sofia.

Possivelmente, o trabalho da enfermagem possuía um fluxo estruturado e organizado nos diferentes serviços acessados por Sofia, porém, por certo, o processo de trabalho desenhado nestas instituições não favorecia práticas que fossem evidenciadas à luz da integralidade. O que aponta, portanto, a necessidade de se discutir os processos de trabalho da enfermagem nos serviços organizados para o enfrentamento do HIV/AIDS. 


\subsection{ITINERÁRIO TERAPÊUTICO: PRÁTICAS QUE POTENCIALIZARAM O EXERCÍCIO DA INTEGRALIDADE}

Ao partir para as situações que favoreceram o exercício da integralidade, foi possível observar que a rede de sustentação e apoio, composta principalmente pela família, amiga, Igreja e alguns profissionais, foram importantes delineadores do percurso em busca de cuidados.

O diagnóstico positivo ao HIV gera mudanças quanto à rede de relações, no que se diz respeito às perdas, aproximações e distanciamentos de pessoas queridas devido ao estigma e preconceito. Diante disto, o apoio da família, que também está sujeito ao preconceito e discriminação, torna-se fundamental, principalmente se a família responder com solidariedade e receptividade (Silveira e Carvalho, 2011), como foi o caso de Sofia, exceto pelo abandono do pai de sua filha.

Como consta nas narrativas, a convivência com o HIV, a necessidade diária das medicações e o medo de ter o diagnóstico revelado a qualquer momento, exigem uma readaptação da vida diária. Para tanto, o apoio familiar é extremamente importante, tendo em vista inclusive sua influência na adesão ao tratamento. Vale lembrar que este suporte oferece vários benefícios para o bem-estar da pessoa vivendo com HIV, inclusive exercendo influências sobre a saúde mental e física, diminuindo direta e indiretamente o estresse psicológico e os problemas de saúde (Silveira e Carvalho, 2011).

Desta forma, considera-se que o suporte social é um dos múltiplos fatores de sucesso do tratamento e acompanhamento da aids (Silva e Junior, 2011). Como se pode comprovar, um estudo na República Dominicana evidenciou forte relação entre a pouca adesão à terapia antirretroviral e a falta de suporte social e familiar (Harris et al, 2011). 
Outro estudo, baseado no modelo de Sistema de Cuidados à Saúde de Arthur Kleinman, analisou as práticas de cuidado de pessoas vivendo com HIV, por meio do Itinerário Terapêutico. As autoras constataram que as práticas de cuidado ultrapassaram o sistema biomédico e atingiram os subsistemas familiar e popular, que assumiram importância significativa no direcionamento das práticas de cuidado. Apontaram, ainda, a importância de se considerar estes subsistemas para o planejamento da assistência, pois observaram que muitos dos cuidados eram pautados no conhecimento familiar e popular e que muitos indivíduos não possuíam espaços, com os profissionais de saúde, para compartilhar as dificuldades relacionadas à experiência de se conviver com o HIV/AIDS (Maliska, Padilha, 2007).

Assim, considerando os estudos que comprovam a importância do suporte familiar no enfrentamento do HIV/AIDS, foi possível concluir, com as narrativas, que o suporte recebido principalmente pela família e amiga influenciou significativamente as escolhas de Sofia. Esta influência consistiu em encorajá-la a buscar cuidados formais de saúde, a realizar o tratamento não somente durante a gestação, a apoiá-la emocionalmente durante todo o tratamento, como também incentivá-la a retomar sua rotina de vida. Ao analisar o papel desta rede de sustentação na trajetória de Sofia, foi possível observar que esta rede influenciou também direta ou indiretamente a "costura do percurso" de Sofia.

Diante disto, este suporte favoreceu duplamente a integralidade: primeiro, ao oferecer cuidado à Sofia, acolhendo seus medos, angústias, dúvidas, não se atendo apenas ao foco de auxiliá-la na adaptação das medicações; e segundo, ao favorecer indiretamente a continuidade da assistência, sem o qual não seria possível a adesão, o acompanhamento nos diversos níveis de complexidade acessados e o sucesso da não transmissão vertical.

Outra consideração sobre a Rede de Sustentação e a Rede de Apoio na trajetória de Sofia, é a presença do sexo feminino nessa Rede. Nota-se 
que, exceto pelos seus irmãos, majoritariamente os principais integrantes desta rede foram mulheres: amiga, cunhada, mãe, médica da equipe de saúde da família e médica infectologista. E contraditoriamente, sendo a profissão de Enfermagem composta predominantemente pelo sexo feminino, esta categoria de profissionais não esteve de forma significativamente marcante em sua trajetória.

Este reflexo do cuidado como atribuição feminina na trajetória de Sofia tem relações com o modo em que homens e mulheres se constituem como sujeitos sociais no contexto da sociedade contemporânea. A formação social da mulher foi sendo construída por uma sociedade que a reconhece como aquela que cuida: da casa, dos filhos, do companheiro, dos familiares e também das questões de saúde e dos problemas de doença. Assim, o cuidado, ao longo do tempo, esteve restrito a ambientes domiciliares (Schaurich e Padoim, 2004). Fonseca (1999) salienta que isso está fortemente associado à antiga divisão sexual do trabalho, em que havia a naturalização feminina do trabalho doméstico e do cuidado com as crianças e a inserção dos homens no espaço social.

Voltando à trajetória de Sofia, ao partir para as práticas ocorridas no contexto dos serviços de saúde, iniciando pela UBS, é possível apontar alguns fatores que foram favoráveis à integralidade, a começar pela facilidade de acesso que teve ao buscar acompanhamento de pré-natal.

Foi possível observar, com as narrativas, que ao buscar atendimento de pré-natal, Sofia se sentiu acolhida pela atenção que recebeu dos profissionais de enfermagem durante o procedimento de coleta de sangue para exames laboratoriais e também porque recebeu atendimento diferenciado diante da alteração da sorologia. $O$ acolhimento no serviço foi além da postura atenciosa e educada dos profissionais. Exigiu também que este serviço estivesse organizado para atendê-la, desde o acesso ao teste de confirmação diagnóstica de gravidez; o rápido acesso à consulta de enfermagem frente à confirmação da gravidez; a organização de sair de uma 
consulta já com uma data de retorno; o acesso à coleta de exames na própria UBS; a vigilância dos exames alterados, a comunicação e antecipação da consulta médica de pré-natal.

Conforme recomendação do Ministério da Saúde, a atenção qualificada e humanizada à gestante envolve provisão de recursos necessários, desde a organização de rotinas e fluxos de atendimentos até o estabelecimento de relações baseadas em princípios éticos (Brasil, 2006b).

Ao considerar o conceito ampliado de acessibilidade (Dever, 1988 apud Giovanella, Fleury, 1995), no que se diz respeito à facilidade de acesso geográfico, à disponibilidade dos serviços em atender o que Sofia buscava e à organização dos serviços para oferecer a assistência desejada, conclui-se que a Atenção Básica atendeu estes requisitos, posto que houve organização da UBS para facilitar o acesso de Sofia, principalmente porque ela se relacionava ao grupo de prioridades por ser gestante e soropositiva ao HIV.

Um estudo realizado no Ceará apontou fragilidades no acesso das gestantes ao pré-natal, como dificuldade em marcar a primeira consulta, procedimento realizado pelas agentes de saúde e não pelas próprias gestantes, bem como a realização dos exames de sorologia para HIV em unidade distante da UBS em que eram cadastradas (Araújo, Vieira e Silva, 2008).

Comparativamente, conclui-se que a UBS, em que Sofia possui cadastro, está organizada para atender casos como o dela, tendo em vista os exemplos de organização já referidos. Conclui-se também que a categoria Acesso foi a primeira a ser destacada no prisma da Integralidade, justamente porque foi pelo acesso que a usuária se inseriu no sistema de serviços de saúde.

Além da acessibilidade, esteve presente a integralidade quando houve acolhimento de Sofia na UBS, no momento da descoberta do HIV. O 
momento de revelação do diagnóstico de HIV é uma situação bastante delicada, pois geralmente este diagnóstico gera impacto negativo na vida das pessoas, principalmente nas que não se percebem vulneráveis ao HIV. Estes sentimentos variam entre indignação, remorso, tristeza, angústia, desespero e, no caso de gestantes, ainda estão associados sentimentos relacionados ao medo de transmitir o vírus para o bebê. Além disso, as gestantes vivenciam preconceitos, dúvidas, mitos e crenças, que acentuam ainda mais os sentimentos negativos frente à revelação do diagnóstico. Assim, o acolhimento do profissional de saúde torna-se fundamental neste momento, e por isso, é necessário que os profissionais tenham perspicácia e sensibilidade no atendimento às muitas demandas geradas após um resultado positivo para o HIV, especialmente quando se trata de gestantes (Araújo et al, 2008). Diante disso, foi possível constatar, com as narrativas, que a médica da ESF atendeu a necessidade apresentada por Sofia, no momento de revelação do diagnóstico.

Destaca-se também na UBS o quanto esta instituição facilitou o acesso de Sofia no SAE, pois além do encaminhamento com formulário de referência, fez contato telefônico e disponibilizou serviço de transporte da UBS ao SAE, tendo em vista o risco de acidente que o estado emocional de Sofia oferecia. Mesmo não tendo utilizado o serviço de transporte, é interessante identificar mais uma organização da UBS e sua respectiva Supervisão Técnica, disponível para ser acionada em casos como este.

No SAE, vários fatores contribuíram para o exercício da integralidade. Dentre eles, Sofia destacou o vínculo estabelecido com os profissionais, em especial com a médica infectologista, como já citado. Nota-se que o acolhimento e vínculo com os profissionais favorece o processo de adesão, inclusive porque ao ouvir os usuários e estimular suas expressões, eles também se sentem mais à vontade para fazer questionamentos, o que favorece a autonomia no seu processo saúde-doença. E conceber este usuário como sujeito de seu processo saúde-doença, de modo que juntos - 
profissionais e usuários - possam implementar o projeto terapêutico, faz parte do atendimento integral às pessoas que vivem com HIV/AIDS (Brasil, 2008b).

Nota-se que o Vínculo desenvolvido com o SAE foi favorecido principalmente pela escuta oferecida pela médica. Ouvir, valorizar o relato do usuário e estimular o usuário a expressar seus conhecimentos, crenças e sentimentos que caracterizam o processo de escuta ativa, tão importante no desenvolvimento de adesão ao projeto terapêutico (Brasil, 2008b). O Ministério da Saúde (Brasil, 2008b) ainda recomenda que haja parceria entre profissional e o usuário "no ouvir, sentir e pensar juntos as soluções para a melhoria da adesão e a superação das barreiras", pois direcionar as condutas com base apenas em ações prescritivas não têm se mostrado eficazes na prática.

Vale ressaltar que é preciso considerar a experiência singular do adoecimento. Nela, estão envolvidos valores, crenças e condições específicas de vida, que devem ser explorados e compreendidos para que o plano terapêutico seja individualizado e faça sentido para a vida do usuário (Oliveira et al, 2005).

Sofia relatou que recebeu acompanhamento multiprofissional. Pelas suas narrativas, foi possível inferir que havia comunicação entre estes profissionais, pois Sofia referiu que antes de ser atendida, as anotações anteriores eram lidas por eles. Logo, o prontuário foi importante meio de comunicação entre estes profissionais. Ao contribuir para a continuidade da assistência, esta comunicação nos remete à reflexão sobre o quanto esta prática pode favorecer o exercício da integralidade, pois possibilita que as diversas categorias de profissionais somem suas ações, minimizando, desta forma, a fragmentação do cuidado.

A facilidade de acesso às consultas também favoreceu o exercício da integralidade no SAE, pois segundo o relato de Sofia, existia um fluxo programado para o atendimento de pessoas vivendo com o HIV. As 
consultas eram agendadas eletronicamente nas respectivas agendas dos profissionais e, além disso, as agendas eram abertas, disponíveis para escolha do usuário. Assim, Sofia conseguia agendar a especialidade que desejasse ou a especialidade que lhe fosse recomendada em horário que Ihe atendesse. Neste exemplo, a categoria Acesso, no que se diz respeito à adequação funcional do serviço, propiciou o exercício da integralidade ao favorecer a continuidade do acompanhamento ao longo do tempo.

A facilidade de acesso geográfico ao SAE também favoreceu sua continuidade no tratamento, pois além de não haver barreira geográfica, o SAE estava localizado em uma avenida, chegando-se ao local por diversas linhas de transporte coletivo. Porém, Sofia sentia-se exposta justamente por esta facilidade de acesso, pois temia que a qualquer momento fosse vista e reconhecida ao entrar no $S A E$, o que aumentava seu receio de ter seu diagnóstico revelado.

Merece ser citada como condição favorável à integralidade a VD de puerpério realizada pela enfermagem e pela terapeuta ocupacional. Esta visita apontou a existência de um fluxo de atendimento à gestante que considera, para o planejamento da assistência, as necessidades com base no território da usuária.

Interessante notar que, em sua curta experiência com a maternidade, conforme discutido anteriormente, não foi possível identificar práticas que favorecessem o exercício da integralidade. Ou seja, de sua narrativa apreenderam-se sentidos que não traduzem este princípio. 
6. CONCLUSÃO E CONSIDERAÇÕES FINAIS 


\section{6 . CONCLUSÃO E CONSIDERAÇÕES FINAIS}

Ao retomar os objetivos do trabalho, que consistiram em contextualizar o percurso realizado em busca de cuidados, a fim de analisar como a organização dos serviços é refletida na trajetória do usuário que vive com HIV e, mais ainda, discutir os nós da integralidade neste percurso, conclui-se que os objetivos foram alcançados, posto que, por meio do IT, foi possível mapear os movimentos da usuária na rede de serviços e compreender como esta organização dos serviços direciona as escolhas na busca por cuidados.

Conclui-se com a utilização do IT, que está no usuário a centralidade da busca por cuidados, logo é ele que exerce o elo entre os diferentes serviços assistenciais de saúde. Notou-se que cada serviço buscou resolubilidade no que era de sua competência, porém atuaram de forma isolada, fragmentada e descontínua. Não utilizaram ferramentas já instituídas para a comunicação, desviando, desta forma, a função de articulação para a usuária e sua família.

Identificou-se neste percurso que os desafios de conviver com o HIV consistiram em: lidar com o risco da transmissão vertical na gestação; omitir o diagnóstico de HIV, por medo do preconceito e isolamento social; e em conciliar a rotina de estudo, trabalho, cuidado com sua filha e mãe, com a necessidade de se manter aderida à terapia antirretroviral.

O objetivo de discutir os nós da integralidade no percurso em busca de cuidados em HIV/AIDS foi alcançado, pois, a partir das categorias operatórias Acesso, Vínculo e Integração, foi possível encontrar, nas narrativas, práticas que favorecessem o exercício da integralidade e práticas que fragilizassem o exercício deste princípio.

Os nós que dizem respeito a fragilidades da integralidade, questão na Atenção Básica foi a não discussão da vulnerabilidade ao HIV em todas as 
oportunidades de contato que a usuária teve nesta instituição, principalmente porque nas consultas era predominante a dimensão biológica do adoecimento.

No SAE, o que desfavoreceu o exercício da integralidade, segundo os relatos, foi a não realização de referência e contrarreferência aos outros serviços de saúde, o que acarretou em assistência fragmentada e descontínua.

$\mathrm{Na}$ maternidade, diversas situações fragilizaram a integralidade, indicando a falta de fluxos bem estruturados para o atendimento de mulheres vivendo com HIV, o que consequentemente gerou práticas que não atenderam integralmente a expectativa das usuárias. Nota-se aqui que a categoria Acesso não foi critério pertinente para avaliar a integralidade, pois apesar de estar sendo assistida e, portanto, inserida no fluxo de atendimento, as práticas não atenderam de forma integral as demandas levantadas pela usuária, diferentemente da categoria Vínculo que apontou ser adequada para avaliar situações desfavoráveis à integralidade.

Destacou-se na trajetória a invisibilidade do trabalho da enfermeira quando se toma como categoria de análise a Integralidade, possivelmente porque suas práticas estiveram mais relacionadas a procedimentos técnicos, não imprimindo marcas da integralidade neste cuidado. Assim, as narrativas apontaram uma reflexão bastante pertinente a esta temática, pois considerando a importância e potencialidade da enfermagem no fortalecimento da integralidade e no cuidado em HIV/AIDS, o estudo indicou a necessidade de se discutir os processos de trabalho da enfermagem nos serviços organizados para o enfrentamento do HIV/AIDS.

A Rede de Sustentação e Apoio conformou-se como importante potencializadora da integralidade, pois este suporte acolheu as demandas que ultrapassaram questões biológicas e influenciou significativamente as escolhas da usuária nesta trajetória. 
Na Atenção Básica, condição favorável à integralidade foi a acessibilidade aos serviços, que exigiu deste nível de complexidade organização do serviço para atender as demandas apresentadas pela usuária, enquanto gestante e soropositiva ao HIV. Conclui-se, assim, que a acessibilidade foi favorável à integralidade, pois a organização deste nível de atenção possibilitou inserção e acolhimento da usuária no sistema de serviços de saúde. Além disso, a Atenção Básica destacou-se por sua potência em promover articulação dos serviços, tendo em vista que foi este nível de atenção que, segundo as narrativas, utilizou os meios de comunicação já existentes para a articulação dos serviços.

No SAE, fortaleceu a integralidade o vínculo estabelecido entre usuária e profissionais. Este vínculo também possibilitou continuidade do acompanhamento neste serviço, contribuindo inclusive para a adesão ao tratamento. Conclui-se, portanto, que a categoria Vínculo foi bastante apropriada para indicar o fortalecimento da integralidade. Além do vínculo, a acessibilidade ao SAE também propiciou o exercício da integralidade, ao favorecer a continuidade do acompanhamento ao longo do tempo.

Ao término deste trabalho, conclui-se que o estudo promoveu reflexões sobre os entraves que dificultam o caminhar do usuário na rede de serviços. Indica-se necessária continuidade dessa discussão em âmbitos de gestão de saúde, a fim de embasar mudanças na política de Atenção em HIV/AIDS no município, visando à implementação de Linhas de Cuidado em HIV/AIDS centradas nas necessidades das pessoas que vivem com HIV.

Aponta-se a necessidade de implementação, no âmbito das políticas públicas e no que diz respeito à gestão nos serviços de saúde, de fluxos estruturados para o atendimento integral da pessoa que vive com HIV/AIDS. Além disso, indica-se necessária a discussão sobre o reducionismo biológico do processo saúde-doença nos serviços de Atenção Básica, não visando apenas à Atenção em HIV/AIDS, mas a todos os usuários que, inseridos em 
um contexto histórico-político, possuem necessidades que não se esgotam no "modelo queixa-conduta".

Tendo em vista a invisibilidade do trabalho da enfermeira, indica-se fomentar, desde o momento da formação acadêmica e nos processos de educação permanente, a inclusão das questões que envolvem a atenção em HIV/AIDS, tomando como referência a integralidade na saúde.

Com relação à produção do conhecimento, este estudo indica a necessidade de investimentos em trabalhos que possam esclarecer, subsidiar e propor transformações nos processos saúde-doença, fomentando, assim, a produção de cuidado integrais em saúde. 


\section{REFERÊNCIAS}

Almeida MCP, Rocha SMM. O trabalho da enfermagem. São Paulo:

Cortez;1997. Considerações sobre a enfermagem enquanto trabalho; 15-26.

Antunes MJM, Guedes MVC. Integralidade nos Processos Assistenciais na Atenção Básica. In: Integralidade da atenção no SUS e sistematização da assistência de enfermagem. Garcia TR, Egry EY, organizadoras. Porto Alegre: Artmed;2010.

Araújo MAL, Vieira NFC, Silva RM. Implementação do diagnóstico da infecção pelo HIV para gestantes em Unidade Básica de Saúde da Família em Fortaleza, Ceará. Ciênc \& Saúde Coletiva. 2008;13(6):1899-906.

Araújo LM, Nogueira LT. Transmissão vertical do HIV: situação encontrada em uma maternidade de Teresina. Rev Bras Enferm. 2007;60(4):396-9.

Araújo MAL, Queiroz FPA, Melo SP, Silveira CB, Silva RM. Gestantes portadoras do HIV: enfrentamento e percepção de uma nova realidade. Cienc Cuid Saude. 2008;7(2):216-23.

Bousquat A, Cohn A, Elias PE. Implantação do Programa Saúde da Família e exclusão sócio-espacial no Município de São Paulo, Brasil. Cad. Saúde Pública. 2006;22(9):1935-43.

Bassichetto, K.C. et al. Perfil epidemiológico dos usuários de um Centro de Testagem e Aconselhamento para DST/HIV. Rev. Bras. Epidemiol. 2004;7(3):302-10.

Bastos FI, Szwarcwald CL. AIDS e pauperização: principais conceitos e evidências operatórias. Cad. Saúde Pública. 2000;16(Sup. 1):65-76.

Bellato R, Araújo LFS, Castro P. O itinerário terapêutico como uma tecnologia avaliativa da integralidade em saúde. In: Pinheiro R, Silva Junior AG, Mattos RA, organizadores. Atenção básica e integralidade: contribuições para estudos de práticas avaliativas em saúde. Rio de Janeiro:

CEPESC/IMS/UERJ/ABRASCO; 2008. p.167-187

Bellato R, Araújo LFS, Faria APS, Costa ALRC e Maruyama SAT. Itinerários terapêuticos de família e redes para o cuidado na condição crônica: alguns pressupostos. In: Pinheiro R, Martins PH, organizadores. Avaliação em saúde na perspectiva do usuário: abordagem multicêntrica. Rio de Janeiro: CEPESC/IMS-UERJ/ABRASCO; 2011. p. 187-194.

Bellato $R$ et al. A história de vida focal e suas potencialidades na pesquisa em saúde e em enfermagem. Rev. Eletr. Enf. 2008;10(3):849-56. 
Brasil. Presidência da República. Casa Civil/Subchefia para Assuntos Jurídicos. Constituição da República Federativa do Brasil. Brasília: Senado, 1988.

Brasil. Lei $n^{0} 7.670$, de 08 de setembro de 1988. Estende aos portadores da Síndrome da Imunodeficiência Adquirida- SIDA/AIDS os benefícios que especifica e dá outras providências. Diário Oficial da União, seção 1:17305. Brasília;1988.

Brasil. Lei Orgânica de Saúde 8.080, de 19 de setembro de 1990. Dipõem sobre as condições para promoção, proteção e recuperação da saúde., a organização e o funcionamento dos serviços correspondentes e dá outras providências [legislação na Internet] . Brasília;1990 [citado 2010 mai. 23]. Disponível em: http://www.portal.saude.gov.br/portal/arquivos/pdf/lei8080.pdf

Brasil. Ministério da Saúde. Gabinete do Ministro. Portaria $n^{\circ} 545$, de 20 de maio de 1993, de 20 de maio de 1993. Normas e procedimentos reguladores do processo de descentralização da gestão das ações e serviços de saúde [legislação na Internet]. Brasília; 1993 [citado 2010 out. 18]. Disponível: http://siops.datasus.gov.br/Documentacao/Portaria\%20545 2005 1993.pdf

Brasil. Ministério da Saúde. Gabinete do Ministro. Portaria GM/MS 2.203, de 06 de novembro de 1996. Dispõem sobre a aprovação da Norma Operacional Básica do Sistema Único de Saúde/ NOB-SUS 96. Brasília;1997 [citado 2010 out. 18]. Disponível em:

http://siops.datasus.gov.br/Documentacao/NOB\%2096.pdf

Brasil. Lei $n^{\circ}$. 9.313, de 13 de novembro de 1996. Dispõem sobre a distribuição gratuita de medicamentos aos portadores do HIV e doentes de AIDS. Diário Oficial da União. Seção 1: 23725. Brasília; 1996.

Brasil. Ministério da Saúde. Conselho Nacional de Saúde. Normas para pesquisa envolvendo seres humanos. Resolução CNS 196/96 e outras/Conselho Nacional de Saúde. Brasília: Ministério da Saúde; 2000. $138 p$.

Brasil. Ministério da Saúde. Secretaria de Assistência à Saúde. Coordenação de Saúde da Comunidade. Saúde da Família: uma estratégia para a reorientação do modelo assistencial. Brasília; 1997.

Brasil. Ministério da Saúde. Secretaria de Assistência à Saúde. Departamento de Descentralização da Gestão da Assistência: aprofundando a descentralização com eqüidade no acesso. Norma Operacional da Assistência à Saúde: NOAS-SUS 01/02 e Portaria MS/GM n.ํ373, de 27 de fevereiro de 2002 e regulamentação complementar. $2^{a}$ ed. Brasília: Ministério da Saúde; 2002. 108p.

Brasil. Ministério da Saúde. Secretaria-Executiva. Programa Nacional de DST e Aids. Projeto Nascer/ Ministério da Saúde, Secretaria-Executiva, Programa Nacional de DST e Aids- Brasília: Ministério da Saúde; 2003. 80p 
Brasil. Lei $n^{0}$. Resolução RDC n. 153, de 14 de junho de 2004. Determina o regulamento técnico para os procedimentos hemoterápicos, incluindo a coleta, o processamento, a testagem, o armazenamento, o transporte, o controle de qualidade e o uso humano de sangue, e seus componentes, obtidos do sangue venoso, do cordão umbilical, da placenta e da medula óssea. Diário Oficial da União. Brasília; 2004.

Brasil. Ministério da Saúde. História do programa nacional: AIDS 20 anos esboço histórico para entender o Programa Brasileiro. Brasília; 2005.

Brasil. Ministério da Saúde. Secretaria de Atenção à Saúde. Departamento de Atenção Básica. HIV/Aids, hepatites e outras DST. Normas e Manuais Técnicos. Cadernos de Atenção Básica, n. 18 Série A. Brasília: Ministério da Saúde; 2006a. 196 p. [citado 2012 abr. 3]. Disponível em: http://bvsms.saude.gov.br/bvs/publicacoes/abcad18.pdf

Brasil. Ministério da Saúde. Secretaria de Atenção à Saúde. Departamento de Ações Programáticas Estratégicas. Área Técnica de Saúde da Mulher. Pré-natal e Puerpério: atenção qualificada e humanizada. Brasília: Ministério da Saúde 2006b. 163 p. [citado 2011 nov. 10]. Disponível em: http://portal.saude.gov.br/portal/arquivos/pdf/manual puerperio 2006.pdf

Brasil. Ministério da Saúde. Secretaria de Vigilância em Saúde. Programa Nacional de DST e Aids. Protocolo para a prevenção de transmissão vertical de HIV e sífilis: manual de bolso. Brasília: Ministério da Saúde; 2007. 180p. [citado 2012 mar. 27]. Disponível em:

http://bvsms.saude.gov.br/bvs/publicacoes/protocolo prevencao transmissa o verticalhivsifilis manualbolso.pdf

Brasil. Ministério da Saúde. Secretaria de Vigilância em Saúde. Boletim Epidemiológico-AIDS e DST. Programa Nacional de DST e Aids. Ano V- $\mathrm{n}^{\circ} 1$. Brasília; 2008a. 64p

Brasil. Ministério da Saúde. Secretaria de Vigilância em Saúde. Programa Nacional de DST e Aids. Manual de adesão ao tratamento para pessoas vivendo com HIV e Aids. Brasília: Ministério da Saúde; 2008b. 130p.

Brasil. Ministério da Saúde. Secretaria de Vigilância em Saúde. Boletim Epidemiológico-AIDS e DST. Programa Nacional de DST e Aids. Ano VIn¹. Brasília: Ministério da Saúde; 2009a. 67p.

Brasil. Ministério da Saúde. Manual operacional do projeto de investimento para a qualificação do Sistema Único de Saúde. QualiSUS-Rede. Série C: projetos, programas e relatórios. Brasília: Ministério da Saúde; 2009b. [citado 2012 abr. 17]. Disponível em: http://portal.saude.gov.br/portal/arquivos/pdf/Manual Operacional QualiSUS .pdf 
Brasil. Ministério da Saúde. Secretaria de Vigilância em Saúde. Boletim Epidemiológico-AIDS e DST. Programa Nacional de DST e Aids. Ano VII- $\mathrm{n}^{\circ}$ 1. Brasília: Ministério da Saúde; 2010a. 56p.

Brasil. Ministério da Saúde. Portaria n 4.279, de 30 de dezembro de 2010. Estabelece diretrizes para a organização da Rede de Atenção à Saúde no âmbito do Sistema Único de Saúde (SUS). Brasília; 2010b. [citado 2012 abr. 5]. Disponível em:

http://bvsms.saude.gov.br/bvs/saudelegis/gm/2010/prt4279 3012 2010.htm

Brasil. Ministério da Saúde. Secretaria de Vigilância em Saúde. Boletim Epidemiológico-AIDS e DST. Programa Nacional de DST e Aids. Ano VIIIn¹. Brasília: Ministério da Saúde; 2011. 26p.

Carvalho CML. Avaliação prospectiva de parâmetros de saúde em portadores do HIV mediante consulta de enfermagem [tese]. Fortaleza: Universidade Federal do Ceará, 2010.

Egry EY, Oliveira MAC, Fonseca RMGS. Considerações a respeito da Saúde Coletiva. In: Egry EY, organizadora. Necessidades em saúde na perspectiva da Atenção Básica: guia para pesquisadores. São Paulo: Dedone Editora; 2008. p. 14-20.

Egry EY, Oliveira MAC, Fonseca RMGS, Cubas MR. Considerações acerca da Saúde Coletiva. In: Garcia TR, Egry EY, organizadoras. Integralidade da atenção no SUS e sistematização da assistência de enfermagem. Porto Alegre: Artmed; 2010. p.64-9.

Egry EY, Oliveira MAC. Marcos teóricos e conceituais de necessidades. In: Egry EY, organizadora. Necessidades em saúde na perspectiva da Atenção Básica: guia para pesquisadores. São Paulo: Dedone Editora; 2008. p. 3340.

Ferraz DAS, Nemes MIB. Avaliação da implantação de atividades de prevenção das DST/AIDS na atenção básica: um estudo de caso na Região Metropolitana de São Paulo, Brasil. Cad Saúde Pública. 2009;25(Sup 2):S240-S50.

Ferreira DC. O itinerário terapêutico de pessoas convivendo com HIV [dissertação]. Juiz de Fora: Faculdade de Medicina, Universidade Federal de Juiz de Fora; 2011.

Fiorin JL. Elementos da análise do discurso. São Paulo: Edusp; 1989.

Fiorin JL, Savioli FP. Para entender o texto: leitura e redação. São Paulo: Ática; 1991. 
Fonseca RMGS. Mulher, direito e saúde: repensando o nexo coesivo. Saúde e Sociedade. 1999;8(2): 3-32.

Fracolli LA, Bertolozzi MR. O trabalho em saúde e o processo de produção: uma questão para a enfermagem. In: Egry EY (organizadora). As necessidades em saúde na perspectiva da Atenção Básica. São Paulo: Dedone Editora; 2008. p. 22-32.

Franco FA. Atenção integral ao HIV/aids: para além da referência e contrarreferência [dissertação]. São Paulo: Escola de Enfermagem, Universidade de São Paulo; 2011.

Franco TB, Magalhães Jr H. A Integralidade na assistência à saúde e a organização das Linhas de Cuidado. In Merhy EE et al. O Trabalho em Saúde: Olhando e Experienciando o SUS no Cotidiano. São Paulo: Hucitec; 2004.

Galvão MTG, Cunha GHMM, Machado MMT. Dilemas e conflitos de ser mãe na vigência do HIV/Aids. Rev Bras Enferm. 2010;63(3): 371-6.

Gerhardt TE. Itinerários terapêuticos em situações de pobreza: diversidade e pluralidade. Cad Saúde Pública. 2006;22(11):2449-63.

Gerhardt TE, Rotoli A, Riquinho DL. Itinerários terapêuticos de pacientes com câncer: encontros e desencontros da Atenção Básica à alta complexidade nas redes de cuidado. In: Pinheiro R, Silva Junior AG, Mattos RA, organizadores. Atenção básica e integralidade: contribuições para estudos de práticas avaliativas em saúde. Rio de Janeiro:

CEPESC/IMS/UERJ/ABRASCO; 2008. p.197-214.

Giovanella L, Fleury S. Universalidade da Atenção à Saúde: acesso como categoria de análise. In: Catalina E, organizadora. Política de Saúde: o público e o privado. Rio de Janeiro: Fiocruz; 1995. p. 177-97.

Guerra MAT. Política de controle da AIDS da Secretaria de Estado da Saúde de São Paulo, no período 1983-1992: a história contada por seus agentes [dissertação]. São Paulo: Faculdade de Medicina, Universidade de São Paulo; 1993.

Gryschek ALFPL. A política de qualificação da força de trabalho em enfermagem no Programa Municipal de doenças sexualmente transmissíveis e aids de São Paulo: um desafio contínuo [doutorado]. São Paulo: Escola de Enfermagem, Universidade de São Paulo; 2001.

Gryschek ALFPL, Domingos JC, Figueiredo CRDL, Nichiata LYI, Osório LM. Necessidades de qualificação da equipe de enfermagem para a assistência aos clientes portadores do HIV e da AIDS. Rev Esc Enf USP. 2000;34(3):288-93. 
Grupo Hospitalar Conceição (GHC). Programas e Projetos. Linhas de cuidado. Linha de Cuidado DST/AIDS. Porto Alegre, 2006. [citado 2012 abr. 17]. Disponível em: http://www.ghc.com.br/default.asp?idmenu=3\#2464

Harris J, Pillinger M, Fromstein D, Gomez B, Garris I, Kanetsky PA et al. Risk Factors for Medication Non-Adherence in an HIV Infected Population in the Dominican Republic. AIDS Behav. 2011;15(7):1410-15.

Hartz ZMA, Contandriopoulos AP. Integralidade da atenção e integração de serviços de saúde: desafios para avaliar a implantação de um sistema sem muros. Cad Saúde Publica. 2004;20(supl.2):331-36.

Ibañez N, Rocha JSY, Castro PC, Ribeiro MCSA et al. Avaliação do desempenho da atenção básica no Estado de São Paulo. Ciênc \& Saúde Coletiva. 2006;11(3): 683-703.

Kalichman AO. Vigilância epidemiológica de AIDS: recuperação histórica de conceitos e práticas [dissertação]. São Paulo: Faculdade de Medicina, Universidade de São Paulo; 1993.

Langendorf TF, Padoin SMM, Vieiras LB, Landerdahl MC, Hoffmann IC. Rede de apoio de mulheres que têm HIV: implicações na profilaxia da transmissão vertical. DST - J bras Doenças Sex Transm. 2011;23(1):16-22.

Leite JL, Erdmann AL, Carvalho SM, Pezzi MCS, Dantas CC. O caminhar para a concepção de um modelo de cuidado ao cliente HIV positivo. Cienc Cuid Saúde. 2007;6(2):18-96.

Lemões MAM, Costa CFS, Mandoza-Sassi RA. Referenciamento de usuários do SUS para um hospital universitário no sul do Brasil. Cienc Cuid Saude. 2009;8(2):198-204.

Longa PALRC, Takahashi RF. A trajetória do portador do HIV: da suspeita da infecção à assistência [dissertação]. São Paulo: Escola de Enfermagem, Universidade de São Paulo; 1999.

Magalhães Júnior HM, Oliveira RC. Concretizando a integralidade nos serviços de saúde: a aposta do SUS em Belo Horizonte. In: Pinheiro R, Ferla AA, Mattos RA, organizadores. Gestão em redes: tecendo os fios da integralidade em saúde. Rio de Janeiro: EdUCS: IMS/ UERJ: CEPESQ; 2006. p.51-64.

Maliska ICA, Padilha MICS. AIDS: a experiência da doença e a construção do itinerário terapêutico. Rev. Eletr. Enf. 2007;9(3):687-98.

Malta DC. Merhy EE. O percurso da linha de cuidado sob a perspectiva das doenças crônicas não transmissíveis. Interf. Comunic. Saúde, Educação. 2010;14(34): 593-605. 
Mattos RA. Os Sentidos da Integralidade: algumas reflexões acerca de valores que merecem ser defendidos. In: Pinheiro R, Mattos RA, organizadores. Os sentidos da integralidade na atenção e no cuidado à saúde. Rio de Janeiro: CEPESC/UERJ, IMS: ABRASCO, 2001. p.39-63.

Matumoto S, Mishima SM, Pinto IC. Saúde coletiva: um desafio para a enfermagem. Cad. Saúde Pública. 2001;17(1):233-41.

Mendes EV. As Redes de Atenção à Saúde. Ciênc. \& Saúde Coletiva. 2010. 15(5):2297-305.

Merhy EE. A perda da dimensão cuidadora na produção da saúde: uma discussão do modelo assistencial e da intervenção no seu modo de trabalhar a assistência. In: Campos CR et al. Sistema Único de Saúde em Belo Horizonte: reescrevendo o público. Belo Horizonte:Xamã/ VM Ed; 1998. p.103-120.

Meneses CS. A unicidade do Sistema Único em questão: a integralidade e a hierarquização do cuidado sob a perspectiva do trabalho vivo [mestrado]. Campinas: Faculdade de Ciências Médicas, Universidade Estadual de Campinas; 1998.

Minayo MCS. História de Vida, Narrativa de Vida, História Oral e Etnobiografia. In: Minayo MCS. O desafio do conhecimento: pesquisa qualitativa em saúde. São Paulo: Hucitec; 2006.

Monteiro MCS, Oliveira MPR. Desconstruindo a verticalização- DST/AIDS e rede básica: uma integração possível. In: Paula IA, Guibu A, organizadoras. DST/aids e rede básica: uma integração necessária. São Paulo: Secretaria de Estado da Saúde; 2007. p. 9-22.

Nichiata LYI. Vulnerabilidade da atenção em HIV/AIDS na Estratégia de Saúde da Família: um estudo de caso no Município de São Paulo [tese livredocência]. São Paulo: Escola de Enfermagem, Universidade de São Paulo; 2010.

Nichiata LYI, Shima H, Takahashi RF. Buscando a compreensão do enfrentamento da AIDS no Brasil. Rev. Latino-am. Enfermagem. $1995 ; 3(1): 149-158$.

Oliveira LA, Landroni MAS, Silva NEK, Ayres JRCM. Humanização e cuidado: a experiência da equipe de um serviço de DST/Aids no município de São Paulo. Ciênc. e Saúde Coletiva. 2005;10(3):689-98.

Organização Pan-Americana da Saúde (OPAS). Linhas de cuidado: hipertensão arterial e diabetes. Organização Pan-Americana da Saúde. Brasília: Organização Pan-Americana da Saúde; 2010. 232 p. 
Paiva V, Latorre MR, Gravato N, Lacerda R, Enhancing Care Initiative. Sexualidade de mulheres vivendo com HIV/AIDS em São Paulo. Cad. Saúde Pública. 2002;18(6):1609-20.

Pereira AJ, Nichiata LYI. A sociedade civil contra a Aids: demandas coletivas e políticas públicas. Ciênc. \& Saúde Coletiva. 2011;16(7):3249-57.

Pinheiro R, Silva Junior AGS. A centralidade do usuário na avaliação em saúde: outras abordagens. In: Pinheiro R, Martins $\mathrm{PH}$,organizadores. Avaliação em saúde na perspectiva do usuário: abordagem multicêntrica. Rio de Janeiro: CEPESC/IMS-UERJ; 2011. p.37-52.

Reis CT, Czeresnia D, Barcellos C, Tassinari WS. A interiorização da epidemia de HIV/AIDS e o fluxo intermunicipal de internação hospitalar na Zona da Mata, Minas Gerais, Brasil: uma análise espacial. Cad. Saúde Pública. 2008;24(6):1219-28.

São Paulo (Município). Secretaria Municipal de Saúde. Programa Municipal de DST/AIDS de São Paulo. I Conferência Municipal de DST/AIDS de São Paulo. Ação e Sustentabilidade. São Paulo; 2002.

São Paulo (Estado). Secretaria de Estado da Saúde. Coordenação dos Institutos de Pesquisa. Ações de prevenção e assistência às DST/AIDS na Rede de Atenção Básica à Saúde do Estado de São Paulo. São Paulo; 2003.

São Paulo (Município). Secretaria Municipal de Saúde. Programa Municipal de DST/AIDS de São Paulo. II Conferência Municipal de DST/AIDS de São Paulo. Integralidade e humanização. São Paulo; 2005.

São Paulo (Município). Secretaria Municipal de Saúde. Coordenadoria de Desenvolvimento de Programas e Políticas de Saúde- CODEPPS. Programa mãe paulistana. Manual técnico: saúde da criança $-1^{\circ}$ ano de vida. São Paulo: Secretaria Municipal de Saúde; 2006. [citado 2011 dez. 5]. Disponível em:

http://ww2.prefeitura.sp.gov.br/secretarias/saude/mae paulistana/manual 1a $\underline{\text { no.asp }}$

São Paulo (Município). Secretaria Municipal de Saúde. Programa Municipal de DST/AIDS de São Paulo. III Conferência Municipal de DST/HIV/AIDS. DST/HIV/AIDS na Metrópole: o desafio das interfaces no SUS. São Paulo; 2009.

São Paulo (Município). Secretaria Municipal de Saúde. Programa Municipal de DST/AIDS de São Paulo. Boletim Epidemiológico de Aids: HIV/DST e Hepatites B e C do Município de São Paulo. Ano XIV, número 13. São Paulo; 2010a. [citado 2011 out. 6]. Disponível em:

http://www10.prefeitura.sp.gov.br/dstaids/novo site/images/fotos/Boletim201 $\underline{0 . p d f}$ 
São Paulo (Município). Prefeitura do Município de São Paulo. Secretaria Municipal da Saúde. Atenção Básica. Estratégia Saúde da Família. São Paulo; 2010b. [citado 2012 abr. 4]. Disponível em: http://www.prefeitura.sp.gov.br/cidade/secretarias/saude/atencao basica/esf/ index.php? $\mathrm{p}=17783$

São Paulo (Município). Prefeitura da Cidade de São Paulo. Mapa dos diversos estabelecimentos de Saúde. Unidades de saúde de rede municipal por Coordenadoria Regional de Saúde e Supervisão Técnica de Saúde. São Paulo; 2010c. [citado 2011 out. 6]. Disponível em:

http://www.prefeitura.sp.gov.br/cidade/secretarias/upload/saude/arquivos/org anizacao/crs sp sts munic.jpg

São Paulo (Município). Secretaria Municipal de Coordenação das Subprefeituras. Dados demográficos dos Distritos Pertencentes as Subprefeituras. São Paulo; 2010d. [citado 2011 out. 6]. Disponível em: http://www.prefeitura.sp.gov.br/cidade/secretarias/subprefeituras/subprefeitur as/dados demograficos/index.php? $\mathrm{p}=12758$

São Paulo(Estado). Secretaria da Saúde. Coordenadoria de Planejamento em Saúde. Assessoria Técnica em Saúde da Mulher. Atenção à gestante e à puérpera no SUS - SP: manual de orientação ao gestor para implantação da linha de cuidado da gestante e da puérpera. São Paulo: SES/SP; 2010 e. $82 p$.

São Paulo (Município). Prefeitura da Cidade de São Paulo. Programa Municipal de DST/AIDS de São Paulo. Guia para o controle de DST/Aids na cidade de São Paulo. São Paulo; 2011. [citado 2012 abr. 4]. Disponível em: http://www10.prefeitura.sp.gov.br/dstaids/novo site/images/fotos/Guia\%200 ngs\%202012.pdf

São Paulo (Município). Prefeitura do Município de São Paulo. Secretaria Municipal da Saúde. Estabelecimentos Municipais de Saúde. São Paulo; 2012a. [citado 2012 abr. 4]. Disponível em: http://www9.prefeitura.sp.gov.br/forms/estabelecimentos saude/index.php

São Paulo (Município). Prefeitura do Município de São Paulo. Secretaria Municipal da Saúde. Coordenação de Epidemiologia e Informação-CEInfo. Número de estabelecimentos /Serviços próprios da SMS por Coordenadoria Regional de Saúde e Supervisão Técnica de Saúde. São Paulo; 2012b. [citado 2012 abr. 4]. Disponível em: http://www.prefeitura.sp.gov.br/cidade/secretarias/upload/saude/arquivos/org anizacao/TabelaEstabServCRSSTS.pdf

Schaurich D, Coelho DF, Motta MGC. A cronicidade no processo saúdedoença: repensando a epidemia da AIDS após os anti-retrovirais. Rev Enferm UERJ. 2006;14(3):455-62. 
Schaurich D, Padoim SMM. Do cuidado da mulher: questões de gênero e sua incorporação no contexto do HIV/AIDS. Esc Anna Nery R Enferm. 2004; 8(1):101-8.

Serra CG, Rodrigues PHA. Avaliação da referência e contrarreferência no Programa Saúde da Família na Região Metropolitana do Rio de Janeiro (RJ, Brasil). Ciênc. \& Saúde Coletiva. 2010;15(Supl. 3):3579-86.

Silva AM, Junior KRC. A invisibilidade da sorodiscordância na atenção às pessoas com HIV/AIDS. Ciênc. \& Saúde Coletiva. 2011;16(12):4865-73.

Silva LMS, Guimarães TA, Pereira MLD, Miranda KC, Oliveira EN. Integralidade em saúde: avaliando a articulação e a co-responsabilidade entre o Programa de Saúde da Família e um serviço de referência em HIV/Aids. Epidem. e Serviços de Saúde. 2005;14(2):97-104.

Silva MASM. Sobre a Análise do Discurso. Rev de Psicologia da Unesp. 2005; 4(1):16-40.

Silva GA, Takahashi RF. A busca pela assistência à saúde: reduzindo a vulnerabilidade ao adoecimento entre os portadores do HIV. Rev. APS. 2008;11(1):29-41.

Silva RMV, Fracolli LA. A utilização de indicadores sociais na operacionalização do modelo de Vigilância da Saúde. Rev Esc Enferm USP. 2007;43(1):168-77.

Silva SF. Organização de redes regionalizadas e integradas de atenção à saúde: desafios do Sistema Único de Saúde (Brasil). Ciênc. \& Saúde Coletiva. 2011;16(6):2753-62.

Silveira EAA, Carvalho AMP. Suporte relacionado ao cuidado em saúde ao doente com aids: o modelo de comboio e a enfermagem. Rev Esc Enferm USP. 2011;45(3):645-50.

Takahashi RF. Marcadores de vulnerabilidade a infecção, adoecimento e morte por HIV e aids [tese de livre-docência]. São Paulo: Escola de Enfermagem, Universidade de São Paulo; 2006.

Teixeira PR. Políticas públicas em AIDS. In: Parker R, organizador. Políticas, instituições e AIDS: enfrentando a epidemia no Brasil. Rio de Janeiro: Jorge Zahar Editor; 1997. p. 43-68.

Tavares FRG, Bonet O. Itinerário terapêutico e práticas avaliativas: algumas considerações. In: Pinheiro, Roseni; Silva Junior, Aluisio Gomes da; Mattos, Ruben Araújo de.Atenção básica e integralidade: contribuições para estudos de práticas avaliativas em saúde. Rio de Janeiro:

CEPESC/IMS/UERJ/ABRASCO; 2008. p.189-196. 
Turienzo G, Mesquita F. Um panorama da luta contra a epidemia de DST/AIDS na cidade de São Paulo. In: Mesquita F, Souza CR, organizadores. DST/AIDS: a nova cara da luta contra a epidemia na cidade de São Paulo. São Paulo: Raiz da Terra; 2003. p. 13-7. 


\section{APÊNDICES}




\section{APÊNDICE}

\section{APÊNDICE 1 - TERMO DE CONSENTIMENTO LIVRE E ESCLARECIDO}

Meu nome é Glauciene Analha Leister, sou aluna do Programa de Pós-Graduação da Escola de Enfermagem da USP e estou realizando um estudo sobre a trajetória nos serviços de saúde, das pessoas que vivem com HIV/AIDS, a fim de futuramente contribuir para melhorias nestes serviços.

Gostaria de convidar você para participar deste trabalho, em que serão realizadas entrevistas sobre sua trajetória nos serviços de saúde, a partir do momento em que soube que era soropositivo. Para tanto, as entrevistas serão gravadas e depois transcritas na íntegra.

Garanto seu anonimato e também garanto que na transcrição das fitas serão excluídos nomes ou qualquer particularidade que possa sugerir identificações. Quando os resultados desta pesquisa forem divulgados, pode ter a certeza de que seu anonimato será totalmente garantido.

É importante lembrar que o senhor (a) não terá custos, nem remuneração para participar desta pesquisa e também não terá prejuízo algum ao seu atendimento nesta ou em outra unidade de saúde, caso não queira participar da pesquisa, lembrando que o senhor(a) tem o direito de desistir da pesquisa em qualquer momento.

Esta pesquisa obedece aos Critérios de Ética em Pesquisa com Seres Humanos, conforme Resolução 196/96. Se você tiver qualquer dúvida ou quiser saber do resultado da pesquisa, entre em contato comigo por email: glausita@gmail.com ou telefone (61)8110-5555 ou se for dúvidas sobre aspectos éticos, poderá entrar em contato com o Comitê de Ética pelo email: smscep@gmail.com ou pelo telefone: (11) 3397-2464. Este Termo de 
Consentimento Livre e Esclarecido será elaborado em duas vias, uma via ficará comigo e outra com o(a) senhor(a).

\section{Obrigada}

Tendo em vista o que li acima, eu de forma livre e esclarecida concordo em participar da pesquisa.

Assinatura do participante da pesquisa

Assinatura do Pesquisador

Assinatura do Orientador

\section{TELEFONES:}

- Escola de Enfermagem da USP. Departamento de Sáude Coletiva. Av. Dr. Enéas de Carvalho Aguiar, 419. Telefone: (11) 3061-7652 e Comitê de Ética em Pesquisa: (11) 3061-7548. Email: edipesa@usp.br

- Comitê de Ética em Pesquisa da Secretaria Municipal da Saúde CEP/SMS. Rua General Jardim, 36 - 1ํandar. Informações/ dúvidas: Fone: 3397-2464 / Fax: 3397-2465 ou e-mail: smscep@gmail.com 


\section{APÊNDICE 2 - ORÇAMENTO DETALHADO DO PROJETO \\ ORÇAMENTO DETALHADO DO PROJETO}

Título do Projeto: Experiência do adoecimento em HIV/AIDS: a trajetória nos serviços de saúde dos usuários inseridos na Supervisão Técnica de Saúde do Butantã- São Paulo

Pesquisador Responsável: Glauciene Analha Leister

Nome da Instituição do Pesquisador Responsável: Escola de Enfermagem da Universidade de São Paulo

Fonte(s) dos recursos (Instituição ou pessoa): recursos provenientes da própria pesquisadora, sem auxílio de outra instituição.

\begin{tabular}{l|c}
\hline & Valor em $\mathrm{R} \$$ \\
Impressora & 348,00 \\
Papel A4 & 200,00 \\
Internet banda larga & 2160,00 \\
Deslocamentos & 3000,00 \\
TOTAL & 5708,00 \\
\hline
\end{tabular}

São Paulo, 15 de agosto de 2011

Pesquisador Responsável

Glauciene Analha Leister

CPF:341.556.238-70 


\section{APÊNDICE 3 - FRASES TEMÁTICAS EXTRAÍDAS DAS NARRATIVAS}

\section{Experiência em busca de cuidados: o viver com HIV, o acesso aos serviços de saúde e às práticas de saúde}

- Nunca imaginou que teria HIV, não acreditava.

- Se não acredita, não há sentido em usar preservativo.

- Se não tem múltiplos parceiros não é promíscua e, portanto, não pega a doença. Conhece a pessoa com que está morando, tem confiança.

- Não sentiu a doença, não sabia o que era, só sentiu os sintomas que achava que era.

- Só depois que soube do diagnóstico é que soube o que acontece com a pessoa quando o vírus entra.

- No corpo há reações fortes, há fases muito difíceis..

- Achava que era uma dor de garganta normal, não tinha remédio.

- O primeiro lugar que foi procurar foi o pronto socorro do plano de saúde, em 2009. Em 2010 descobriu que estava com a infecção.

- Apareceu as alergias no corpo que foi questionado se eram da doença.

- Voltou ao pronto socorro, não foi pedido exame, não houve encaminhamento a lugar nenhum,

- Sentimento de perda 
- Sentimento de culpa, porque poderia ter transmitido a outro. Mais chateada com esta possibilidade do que com quem pode ter transmitido para ela.

- Medo de ter transmitido pra alguém.

- Teve dias que parou de tomar medicação para testar se poderia ficar sem.

- Voltou a seguir em frente, caminhar, explicando que não adianta ficar pra baixo.

- Vive com medo de que alguém saiba.

- Nunca teve reação da infecção no corpo.

- Tem que tomar três comprimidos de manhã e, três comprimidos durante à tarde.

- Atrasa a realização do exame de carga viral.

- Sabe que não toma a medicação como deveria.

- Não fala mais sobre a dificuldade de tomar a medicação com o SAE porque passou.

- Quando contou sobre a dificuldade de tomar a medicação com o SAE viu que não tinha muita alternativa, segundo o que Ihe foi falado.

- De lazer, gosta de caminhar em parque e de assistir filme em cinema.

- Quer trocar de carro e fazer poupança pra dividir com a filha.

- Pensa em não deixar desamparada sua filha,

- Pensa na morte, mas fica mais segura se não deixar a filha desamparada 


\section{Acesso à Atenção Básica e as práticas de saúde ocorridas neste nível de atenção}

- Estranhou antecipação da consulta

- Médica da equipe de saúde da família foi uma amiga, porque largou tudo o que ela havia para fazer, para dar assistência específica para Sofia.

- Satisfeita com o atendimento de pré-natal.

- Satisfeita com o encaminhamento do pré-natal para a consulta médica, sem ter que entrar no fluxo normal de marcação de consulta.

- Sentiu-se acolhida pela médica, pois esta esteve ao seu lado no momento em mais precisava.

- Recusou transporte ao SAE de ambulância, pois não queria exposição.

- Comunicação do posto para o SAE.

- Não sente necessidade de acompanhar na UBS, porque faz tudo pelo SAE.

- Reclama que as agentes tem foco sua mãe e não ela mesma. Reclama que não perguntam sobre sua saúde.

- Não se sente confortável com a insistência da ACS em saber o motivo de não realizar puericultura na UBS.

- A visita da agente tinha como foco a carteirinha de vacinação.

- Destaca os profissionais que a visitaram: ACS e pessoas da enfermagem.

- Enfatiza a educação e simpatia dos profissionais da visita domiciliária.

- Solicita às ACS que não registre as informações da VD. 
- Reclama do atendimento da UBS relacionado à vacina de rotavírus.

- Reclama da necessidade de ter que se expor ao explicar o motivo de atraso da segunda dose da rotavírus.

- Recebeu orientação de não ir mais a UBS para não ter que se expor novamente.

- Percebe melhora da organização da UBS após o programa da saúde da família.

- Relata não ter recebido orientações sobre HIV/AIDS, apenas em cartazes e na televisão da recepção.

Acesso ao Serviço Especializado e as práticas de saúde ocorridas neste nível de atenção

- Elogia atendimento recebido no SAE.

- Percebe comunicação da UBS com o SAE, ao chegar no SAE e perceber que a assistente social já sabia do seu caso.

- Relata os profissionais que acolheram no momento inicial: assistente sócia e psiquiatra.

- Enfatiza o acolhimento que recebeu no SAE, diante do seu quadro de desespero e angústia.

- Relata preferir o SAE porque não precisa repetir sua história em todo atendimento.

- Sentiu-se acolhida desde o primeiro momento no SAE. 
- Faz parte do Programa Mãe Paulistana, recebe cartão de transporte e leite, além do enxoval.

- Relata o primeiro acolhimento no SOU (serviço de orientação ao usuário) para quem vai ao SAE, tanto para tirar dúvidas, quanto para fazer o teste rápido.

- Atendimento multiprofissional para tudo o que precisar: psicóloga, psiquiatra, nutricionista, infecto, dentista, ginecologista e terapeuta ocupacional.

- Relata a escuta da médica infectologista, que ouviu sua história de vida, seus relacionamentos e seus desabafos. Enfatiza que não foi tratada apenas para checar os exames, mas também foi tratada com carinho.

- Fácil acesso às consultas no SAE, que são marcadas tanto por indicação do serviço, quanto por sua vontade.

- Pré-natal registrado no cartão de pré-natal, com informações sobre o tamanho do feto, sobre as ultrassonografias e sobre tudo o que ocorria no pré-natal. Enfatiza que recebeu orientações para andar sempre com este cartão.

- Percebe que todo o processo anotado em prontuário.

- Relata que os profissionais liam o prontuário antes de cada atendimento.

- Atendimento de enfermagem só nos exames laboratoriais.

- Recebeu visita de puerpério da enfermagem e da terapeuta ocupacional, com orientações sobre os pontos da cesárea e avaliação do bebê.

- Não percebeu comunicação do SAE com a maternidade.

- Encaminhada ao dermatologista e oculista, mas não sabia se estes serviços sabiam do seu diagnóstico. 
- Refere não ter levado papel de encaminhamento ao dermatologista e nem ao oculista.

- Não recebeu orientação da enfermagem sobre a contraindicação do aleitamento materno. As orientações de pré-natal eram sempre do médico, mas a orientação do aleitamento foi com a nutricionista.

- Reclama que não recebeu todas as orientações que precisava do médico e ficou revoltada quando descobriu que teria que dar leite no copinho. Teve que ser acompanhada por um terapeuta, porque não aceitava a contraindicação do aleitamento.

- Refere que não tinha o que falar do SAE.

\section{Acesso à Atenção Terciária e as práticas ocorridas neste nível de atenção}

- Buscou o pronto socorro várias vezes e não encontraram nada.

- Médicos da maternidade não leram o cartão de pré-natal, apenas leram quando Sofia indicou ser reagente ao HIV.

- A conduta médica mudou quando viram que era soropositiva ao HIV: estava de alta e teve que ir direto para a sala de parto.

- O leite do bebê sempre atrasava.

- Percebe que as enfermeiras de um período eram muito atenciosas, mas a do plantão noturno não tratavam as pacientes como pessoa.

- Apenas foi a maternidade para o parto, não teve comunicação da maternidade com o SAE. 
- Medo de exposição do diagnóstico a cada novo profissional de enfermagem que a abordava.

- As enfermeiras precisam saber do diagnóstico, mas precisam ser discretas.

- Incomodava-se com o atraso do leite do bebê.

- Médica havia prescrito para aumentar a dose, mas não ofereciam o leite na dose aumentada.

- Reclama dos profissionais do plantão noturno que não atendiam quando eram chamados.

- Revolta-se com a falta de humanização do plantão noturno.

- Refere que no período da manhã os horários eram cumpridos, enquanto no período da noite eram profissionais mal-humorados.

\section{Fontes de apoio e sustentação}

- Teve colega como sua irmã, uma ajudadora.

- O ex-namorado lhe ajudou muito ouvindo suas angústias.

- Família foi seu principal apoio, principalmente seu irmão mais velho, que a ouvia em todos os momentos.

- Igreja Comunidade Carisma como um serviço de apoio.

- Deus como apoio e não como castigador.

- Os profissionais do SAE a apoiaram tanto com apoio psicológico, quanto apoio físico.

- Refere que o SUS a apoiou demais. 
ANEXO

\section{ANEXO 1: PARECER DE APROVAÇÃO DO COMITÊ DE ÉTICA DA PREFEITURA DE SÃO PAULO}

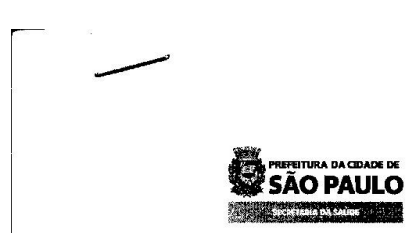

Ima. Sra.

Glauciene Analha Leister

\section{SECRETARIA MUNICIPAL DA SAÚDE Comitê de Ética em Pesquisa/SMS}

CAAE: 0076.0.196.162-11

São Paulo, 03 de Agosto de 2011 PARECER $N^{\circ} 246 / 11$ - CEP/SMS

Projeto de Pesquisa: Experiência do adoecimento em HIV/AIDS: a trajetória nos serviços de saúde dos usuários inseridos na Supervisão Técnica de Saúde do Butantã-Sāo Paulo Pesquisador Responsável: Glauciene Analha Leister

Instiłuição: Escola de Enfermagem da Universidade de São Paulo

Local onde os dados serão coletados: UBS: Jd DÁbril, VI Dalva, Paulo VI, São Jorge e SAE Butantã

Patrocinador: a pesquisadora

\section{I - Sumário Geral do Protocolo}

O objeto de pesquisa é a trajetória dos usuários soropositivos na busca por cuidados. Apresenta-se inicialmente o desenvolvimento das políticas de enfrentamento, que se estruturaram diante da magnitude da epidemia. Destacou-se o pioneirismo do Estado de São Paulo, devido à atuação dos militantes pelos direitos dos homossexuais, que em 1983 procuraram a Secretaria do Estado de Sāo Paulo exigindo respostas diante da problemática HIV/AIDS. Em 1986 foi criado o Programa Nacional de Combate ao HIV/AIDS, quando 11 estados já contavam com programas estruturados. No município de São Paulo, as primeiras açōes de responsabilidade da Secretaria Municipal da Saúde iniciaram-se em 1987, com a criação do Programa Municipal de Prevenção e Controle de DST/AIDS. Este programa se fortaleceu ao longo do tempo, favorecendo a estruturaçáo de um arcabouço de serviços no munićpilo, com ações voltadas tanto no nível de atenção primária, quanto cabouço de serviços no município, com açōes voltadas tanto no nível de atenção primária, quanto serviços, com ênfase nos serviços de Atenção Básica e especializada. O estudo tem como objetivos descrever o percurso realizado pelo usuário em busca de cuidados, a partir do diagnóstico de HIV; discutir a articulação entre as instituições formais de saúde (serviços de saúde da Estratégia Saúde da Família e da Atenção Especializada) e apontar e analisar os nós críticos da integralidade nos percursos empreendidos pelos usuários. O estudo é de caráter exploratório, de natureza qualitativa. tem como perspectiva teórica-conceitual a integralidade e como técnica a História de Vida Focal (HVF), com a construção do Itinerário Terapêutico (IT). Para análise dos dados, será utilizada a técnica de análise de conteúdo proposta por Bardin

Os sujeitos da pesquisa serão pessoas vivendo com HIV/AIDS, moradores na área de abrangência das equipes de ESF, da Supervisão de Saúde do Butantã.

Para ciência e autorização da pesquisa na respectiva área de abrangência, o projeło será inicialmente explicitado a cada gerente das UBS escolhidas, bem como apresentado à coordenação da Supervisão Técnica de Saúde do Butantã. Após este contato inicial, será acionado o profissional da Vigilância de cada UBS, que é o profissional com ciência dos casos de aids na respectiva área de abrangência e em seguida, será feito contato com o usuário a partir do profissional que tenha maior vínculo com este usuário e que compartilha o diagnóstico. Este profissional fará o convite a participar da pesquisa e com a aceitação e assinatura do Termo de Consentimento Livre e Esclarecido, serāo agendados encontros na própria unidade para a realizaçāo das entrevistas.

\section{II - Considerações}

A Folha de Rosto está corretamente preenchida.

O currículo do pesquisador responsável está de acordo com a proposta da pesquisa

O cronograma e o orçamento detalhado estão adequados, os custos do projeto estarão a cargo da pesquisadora.

A metodologia é adequada aos objetivos.

* Rua Ceneral Jardim, $36-1^{\circ}$ andar - V. Buarque - fone: 3397.2464 - email: smscep@gmail.com

http://www.prefeitura.sp.gov.br/cidade/secretarias/saude/comite_de_etica/

Página 1/2

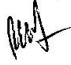


SECRETARIA MUNICIPAL DA SAÚDE Comitê de Ética em Pesquisa/SMS

CAAE: 0076.0.196.162-11

Termo de Consentimento Livre e Esclarecido (TCLE) está redigido na forma de convile, sendo adequado para o tipo de pesquisa.

Os clireitos fundamentais do sujeito de pesquisa estão garantidos

III - Situaçāo do Protocolo - APROVADO

Antes do inicio da coleta de dados, alertamos para a necessidade de contato com o gerente da unidade quando não foi ele quem autorizou a realizaçāo da pesquisa.

O sujeito de pesquisa (ou seu representante) e o pesquisador responsável deverão rubricar todas as folhas do Termo de Consentimento Livre e Esclarecido - TCLE apondo sua assinatura na última página do referido Termo, conforme Carta Circular no 003/2011 da CONEP/CNS.

Salientamos que o pesquisador deve desenvolver a pesquisa conforme delineada no protocolo aprovado. Eventuais modificaçōes ou emendas ao protocolo devem ser apresentadas ao CEP de forma clara e sucinta, identificando a parte do protocolo a ser modificada e suas justificativas.

O relatório final deve ser apresentado do CEP, logo que o estudo estiver conclúdo.

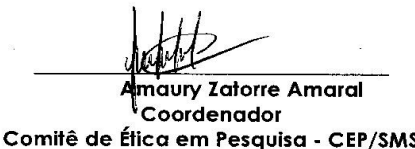

* Rua General Jardim, $36-1^{\circ}$ andar - V. Buarque - fone: 3397.2464- emaiI: smscep@gmail.com 